

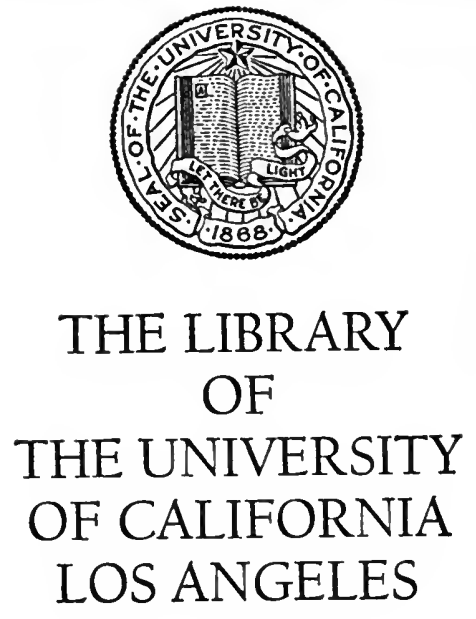

GIFT OF

Clark J. Milliron 


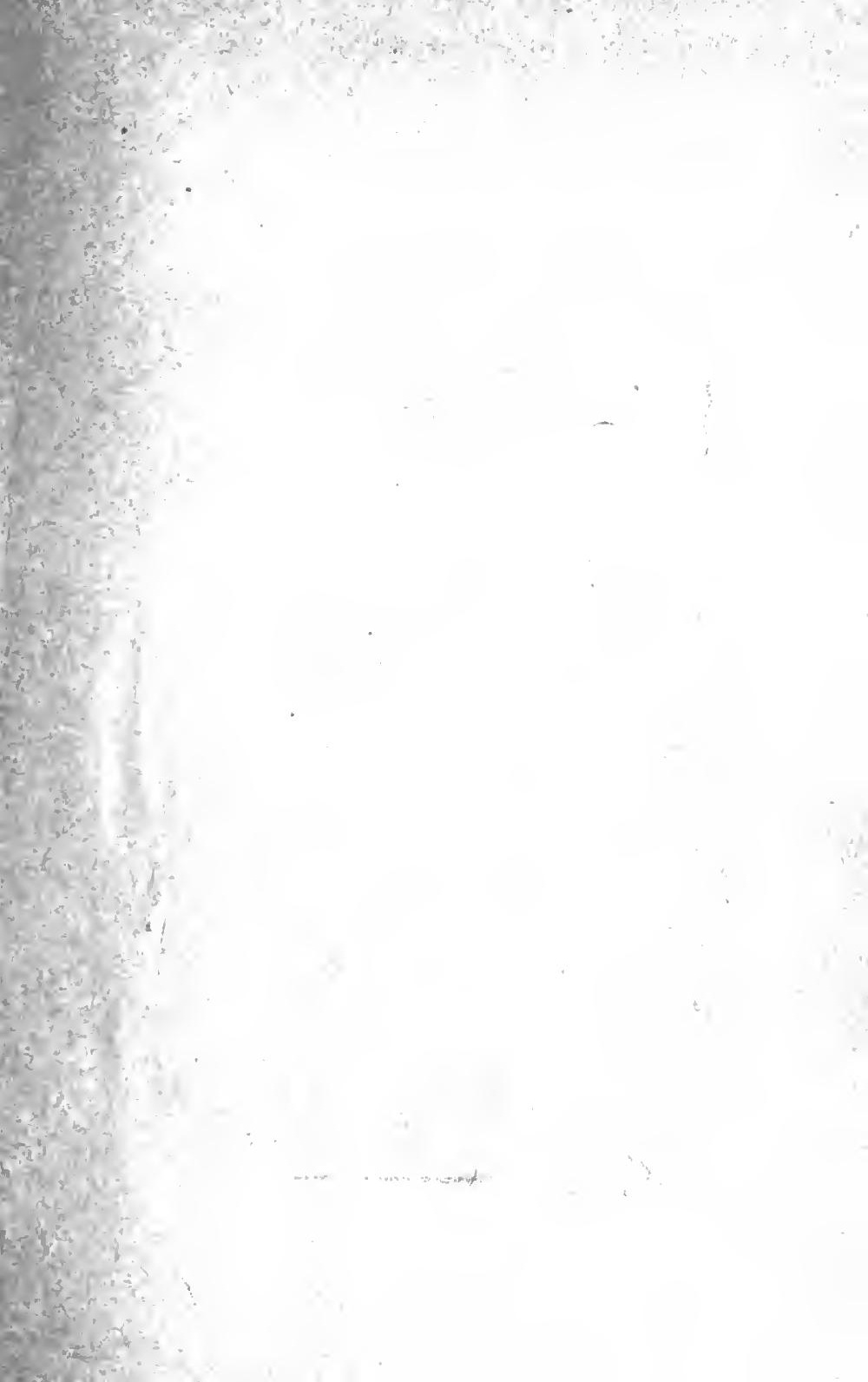


Digitized by the Internet Archive in 2007 with funding from. Microsoft Corporation 


\section{SELF-GOVERNMENT IN THE PHILIPPINES}






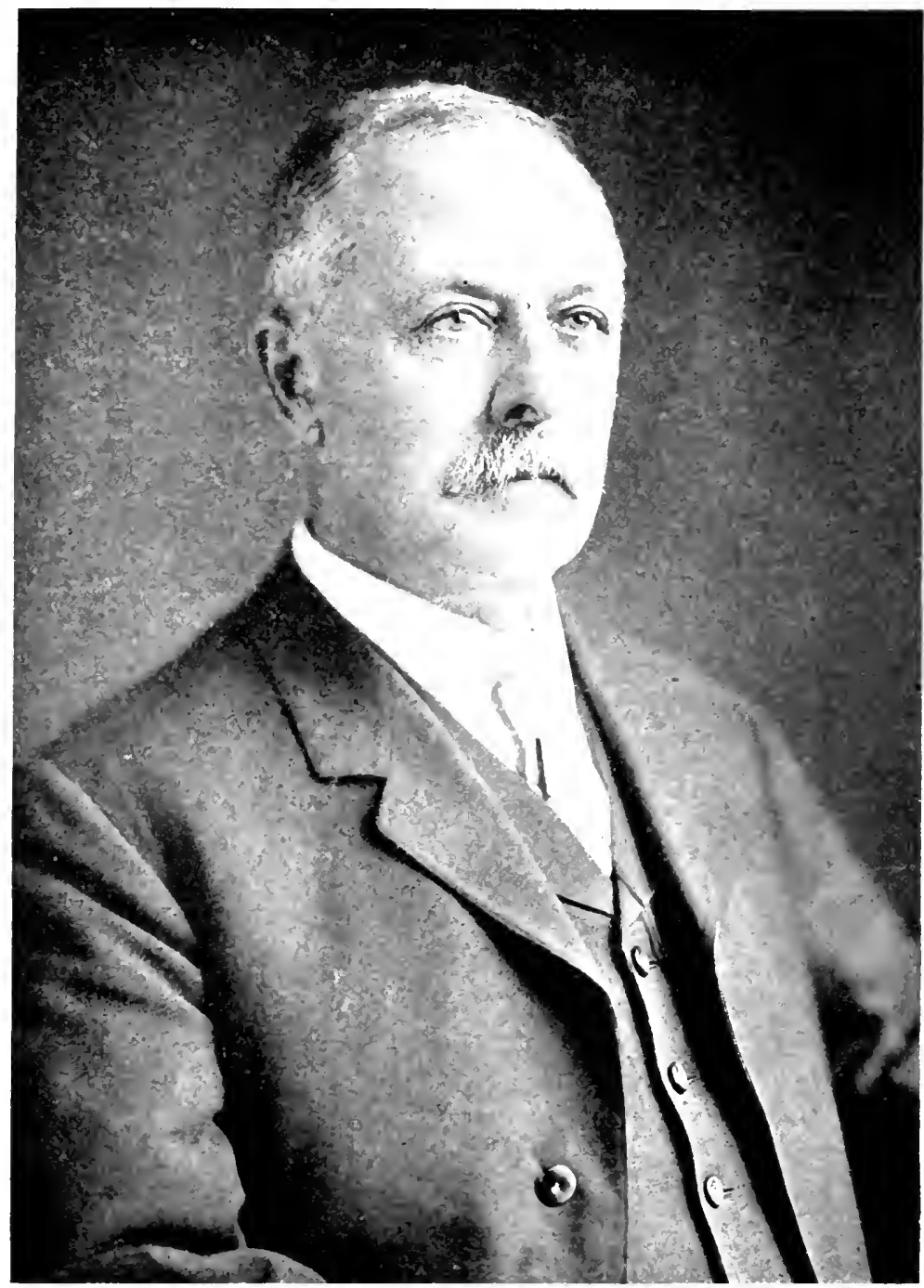

a Harre d Fuing

THE LATE REPRESEXTATIVE WILLIAM ATKINSON JONES OF VIRGINIA Author of the Jones I,aw, and a lifetime friend of the Filipino people. A monument is being erected to his menory in lianila, and he has become one of the immortals of the Philippines 


\section{SELF-GOVERNMENT IN THE PHILIPPINES}

BY

MAXIMO M. KALAW

Chief of the Department of Political Science, University of the Philippines, Secretary of the Philippine Mission to the United States, author

"The Case for the Filipinos"

ILLUSTRATED WITH PHOTOGRAPHS

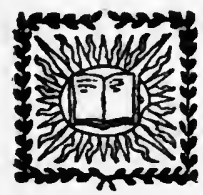

NEW YORK THE CENTURY CO.

1919 
Copyright, 1919, by The Century Co.

Published, June, 1919 
$S$

685

Kids

TO

THE FOUNDERS OF PHILIPPINE NATIONALITY

WHOSE AIMS AND IDEALS

WE HAVE STRIVEN TO ACCOMPLISH

825842 



\section{PREFACE}

Although America's policy in the Philippines has always been founded on the extension of self-government to the people, the Filipino people did not exercise any decisive control in the public affairs of their country until 1913, when they were given a majority in the upper house, or Philippine Commission, besides the control they had of the lower house, or Assembly. Again, a far greater step toward autonomy and independence was taken in 1916, when the Congress of the United States passed the Jones Law, or Philippine Autonomy Act, pledging the people of the United States to recognize the independence of the Philippines "as soon as a stable government can be established therein" and giving the Filipino people, as a preparation for that independence, the largest amount of autonomy compatible with the exercise of the rights of American sovereignty.

Nearly six years have elapsed since the Filipino people were given control of the two 
houses of legislature, and three years since the American Congress passed the Jones Law. Convinced that the condition imposed by the American people precedent to the granting of independence is already fulfilled, the Philippine Legislature sent a Special Mission to the United States to certify the fact and to urge the fulfillment of the American pledge.

At this juncture, when the problems of Philippine independence may be finally adjusted, it is desirable to place before the public a record of what the Filipino people have done since the establishment of Philippine autonomy, and the reasons which impel them as a people to demand their separation from the United States. It is with this end in view that the following chapters are written.

In the preparation of this volume, the writer has been under special obligation to officials and citizens of the Philippines, chief among whom are the Honorable Manuel L. Quezon, President of the Philippine Senate and Chairman of the Philippine Mission to the United States, who has kindly consented to write an introduction; the Honorable Sergio Osmena, Speaker of the Philippine House of Representatives and Vice-Presi- 
dent of the Council of State, who has really inspired the writer to undertake the work; the Honorable Rafael Palma, Secretary of the Inte. rior and Vice-Chairman of the Philippine Mission to the United States, who has placed several memorandums and valuable materials at the disposal of the writer; the Honorable Dionisio Jakosalem, Secretary of Commerce and Communications and member of the Philippine Mission, who has furnished the writer with data and materials on the commerce of the Philippines; the Honorable Clyde H. Tavenner, formerly Member of Congress from Illinois; the Honorable Jaime C. de Veyra, Resident Commissioner from the Philippines and ex-officio member of the Philippine Mission; the Honorable Miguel Unson, Under Secretary of Finance; Dr. W. W. Marquardt, Director of Education, who has given the writer materials on education; Mr. Jose Abad Santos, special attorney for the Philippine National Bank and member of the Philippine Mission, who has encouraged the writer with suggestions; Professor Conrado Benitez, Dean and Professor of Economics, University of the Philippines, and member of the Philippine Mission; Mr. Antonio de las Alas, Assistant Chief, Executive Bureau; 
Dean Jorge Bocobo, Dean of the College of Law, University of the Philippines, and member of the Philippine Mission; and Dr. Louis F. Snow, Chief of the Department of English, University of the Philippines.

M. M. K. 


\section{INTRODUCTION}

A more timely book on the Philippines could not have been written. The United States has promised to grant independence to the Philippines as soon as a stable government can be established therein. The Filipino people are now urging the redemption of that promise on the ground that they have already fulfilled the condition thus imposed.

At this juncture, Professor Kalaw's book should prove of commanding interest. He describes the establishment and organization of the new government under Filipino control, reviews the accomplishments of that government, and portrays the possibilities of an independent Philippines. As a Filipino, he is naturally biased in favor of his people, but in no instance has he allowed his patriotism to distort his facts.

There are perhaps very few men in the Philippines who can speak with as much intimate and comprehensive knowledge of the subject as the 
author. He has long been a deep student of the Philippine question. In the present book, he takes up the subject where he left it in "The Case for the Filipinos" in 1916. I sincerely hope that he will very soon be writing a third volume entitled "The Philippine Republic."

Manuel L. Quezon. 


\section{CONTENTS}

I Our Covenant with America . . *

A résumé of Filipino-American relations up to the passage of the Jones Law.

II The Organization of the New GovernMENT . . . . . . . . . . 18

Governmental organization under the Jones Law - The Cabinet and Council of State - The Governor-General - Nature of the New Government - Extent of Philippine Autonomy.

III The Philippine Budget System . . . 44

The establishment of a scientific system of government finance-Excellent conditions of the public purse.

IV Fimipino Loyalty During the War . $\quad 59$

Filipino participation - Adherence to American ideals - The destroyer and submarine Liberty Bonds - The offer of 25,000 men The inexcusable delay in its organization Peace and order in the Philippines during the war-President Wilson's official recognition of Filipino coöperation.

V Eсомомic Development . . . . .

False prophesies about our economic development - Public works - Growth of commerce - Unprecedented increase of business activities - American capital.

VI Progress of Local Government . . . 92

Extension of autonomy to municipal and provincial governments - Local government a success. 


\section{CONTENTS}

VII OUR Treatment of the Non-Christian

TrIBES . . . . . . . . . . 109

The policy of the government - Attraction and assimilation - Growth of schools - Filipino teachers, doctors and nurses-The Public Works program-Unparalleled treatment of non-Christian tribes.

VIII A Stable Government Established . 129 Meaning of "stable government"-American recognition of new states - Establishment of a "stable government" in Cuba - The fulfillment of the condition imposed by the Jones Law - The Declaration of Purposes of the Philippine Congress - A stable government established in the Philippines - Statements by Governor-General Harrison and Acting Governor Yeater.

IX The Promise of the Philippines . . 158

The Philippines as an Oriental country - Advantages of her geographical situation - Her relations with Japan - Her rôle as democracy's vanguard in Asia - Future relations with the United States.

APPENDICES

A The preamble to the Jones Law . . . 181

B The Declaration of Purposes by the Philippine Legislature . . . . . . 183

C Instructions of the Commission of Independence to the Philippine Mission to the United States . . • . . . . 196

INDEX

203 


\section{LIST OF ILLUSTRATIONS}

The Late Representative William Atkinson Jones

of Virginia . . . . . . . . Frontispiece The First Falls of the Pagsanjan . . . . . 4

The Monument of Padre Miguel de Benavides . 5 The First Philippine Assembly, Inaugurated

1907 . . . . . . . . . . . 12

The Honorable Francis Burton Harrison . . 13

José Rizal . . . . . . . . . . . . 24

A Glimpse of Portion of old Manila . . . . 25

Honorable Sergio Osmena . . . . . . . 32

Honorable Cayetano Arellano . . . . . . 33

The Philippine Cabinet . . . . . . . 48

Palico River Bridge on Batangas-Nasugbu Road . 49

The Philippine Senate . . . . . . . 56

Liberty Loan Parade, Manila . . . . . 57

Battalion Ceremonies, Philippine National Guard 68 Modern Method of Plowing Land for Sugar Cane

Production in the Philippines . . . . 68

Honorable Jaime C. de Veyra . . . . . 69

Honorable Teodoro R. Yangco . . . . . 69

Shipping Scene in the Pasig River . . . 76

Vaughan Bridge, San Juan River, Calamba,

Laguna . • . . . . . . . . 77 


\section{ILLUSTRATIONS}

The Paco Market, Manila . . . . . .

Laguna . . . . . . . . . . . . 81

The Pangasinan Capitol Building . . . . 96

Marabural Bridge, Cagayan Province . . 97

A Class in a Public School of the Philippines . . 104

Ifugao Igorrot Rice Terraces . . . . . . 105

Harrison Bridge . . . . . . . . . . 120

Ayuntamiento Building, Manila . . . . 121

The Honorable Manuel L. Quezon .. . . 136

The Philippine Mission to the United States . 137

University Hall, University of the Philippines . 152

Rafts of Cocoanuts . . . . . . . . . 153

A View from One of the 16 Provincial Trade Schools . . . . . . . . . . . 168

The Machine Shop, School of Arts and Trades,

Manila . . . . . . . . . . . 168

The Famous Luneta, of Manila . . . . 169 


\section{SELF-GOVERNMENT IN THE PHILIPPINES}





\section{SELF-GOVERNMENT IN THE PHILIPPINES}

\section{CHAPTER I}

OUR COVENANT WITH AMERICA

THE Jones Law, or Philippine Autonomy 1 Act, passed by the American Congress on August 29, 1916, marked a new era in the Philippines and established a new basis for FilipinoAmerican relationship. Hitherto, the American government in the Islands had rested on force and not on the consent of the Filipino people. It is with reluctance that we shall have to refer to the rather unpleasant past, not with. the view of renewing old misunderstanding, but in order to better appreciate the present friendly and cordial relations between the American and Filipino peoples. The Treaty of Paris which transferred the Philippines to the United States was secured, not only without the consent of the Filipino people, but in defiance of their opposition. During the negotiation of 
that treaty, the Philippine Republic sent an official representative to Paris to express the views of the inhabitants of the Islands the fate of which was being so momentously decided. This official was not eren given a hearing at the Peace Conference.

After the signing of the treaty, he went to America, but the door of the Washington government was equally closed against him. After the opening of hostilities between the American and Filipino forces, the Filipinos asked for a cessation, suggesting that conferences be held by representatives of both the American and Filipino peoples to deal with the future political relations between the two countries, but the plan was rejected. The American military commander replied that once the fight had started it had to continue to the bitter end. President McKinley, who was, unfortunately, misinformed on Philippine conditions, told the American nation that it was not a Filipino people that was opposing American rule, but only one of the eighty tribes inhabiting the Islands.

From the very beginning of the discussion of the Philippine question, the retentionists have endearored to show that the majority of the Fili- 


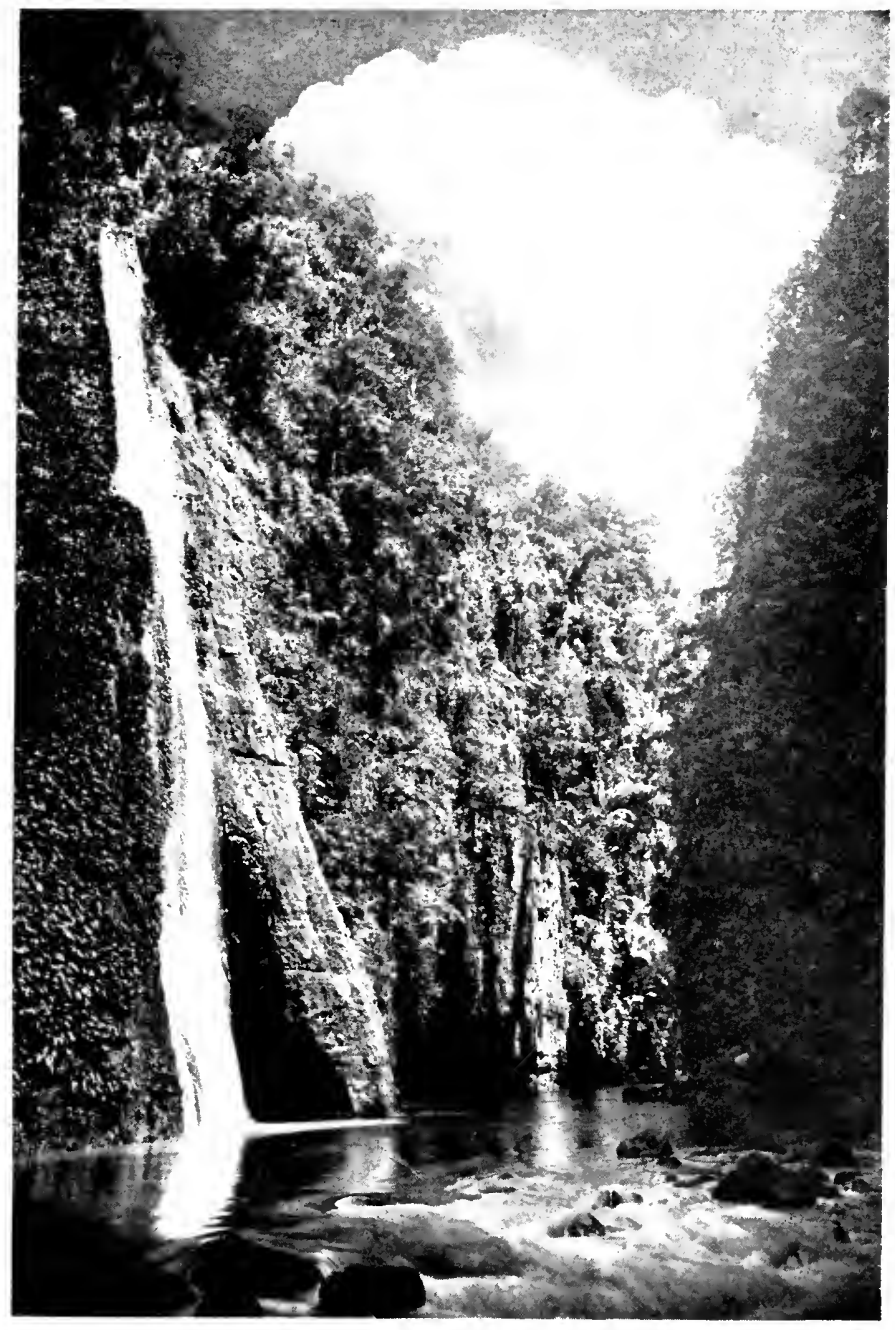




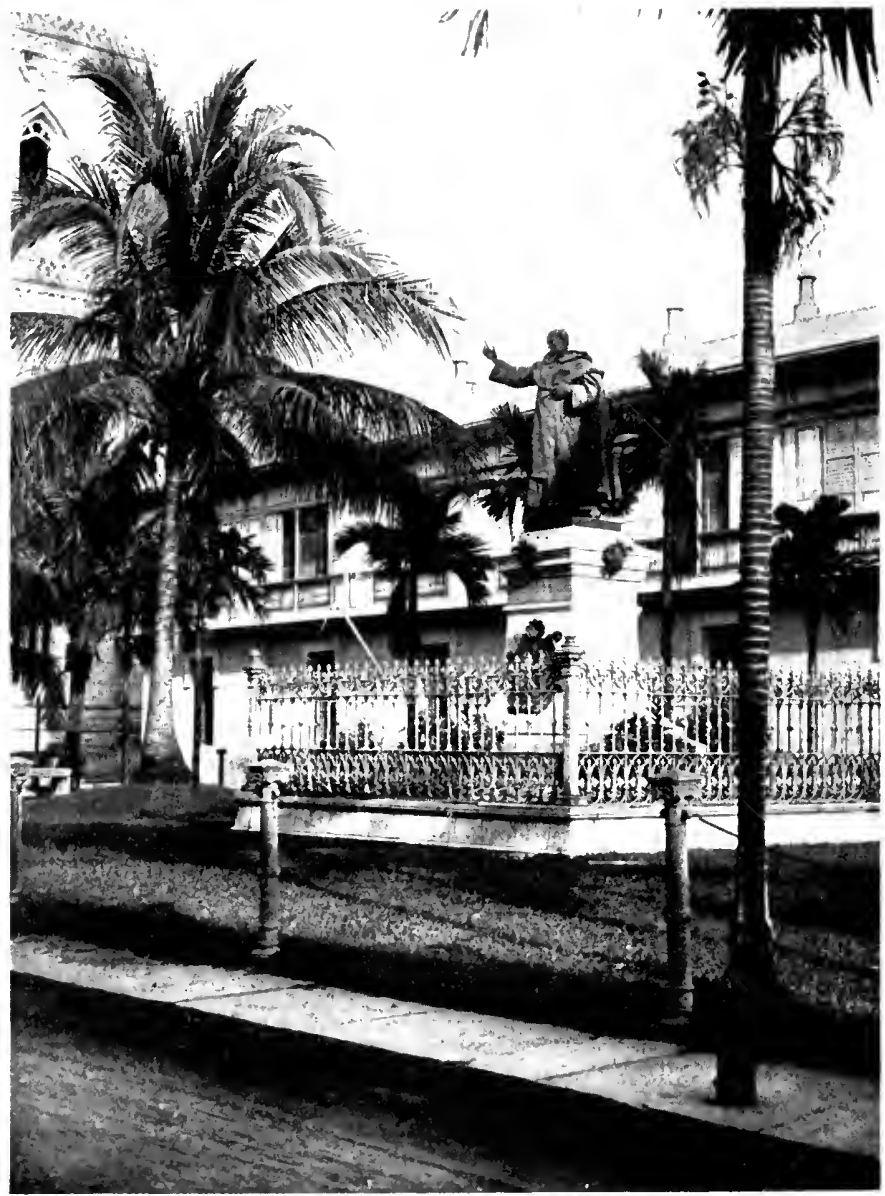

THE MONUMENT OF PADRE MIGUEL DE BENAVIDES

The founder of Santo Tomas University. This monument stands in University Plaza de Santo Tomas, Manila. Santo Tomas is older than Harvard University 
pino people were on their side, for they dared not contradict the principle that wherever the American flag flies, there the wishes of the majority must be respected. President McKinley was loudest in his assurance to his people that his manifestos and the forcible extension of American sovereignty were welcomed by the majority of the Filipino people. After nearly a year of constant fighting, when most American officials had confessed that they had undervalued the determination and tenacity of the Filipino insurgents and when he himself had already sent about 80,000 soldiers to the Islands, he still asserted that the majority of the Filipino people favored American rule. "I had reason to believe," he said in his message of December, 1899, "and I still believe that this transfer of sovereignty was in accordance with the wishes and the aspirations of the great masses of the Filipino people."

In answer to the insistent demands of the Democrats during the election of 1900 that the Philippines should be allowed to establish a stable government and then be given their independence and that if they were not able to protect themselves from foreign aggression that American protection be extended them, President McKinley replied: "The American people 
are asked by our opponents to yield the sovereignty of the United States in the Philippines to a small fraction of the population, a single tribe out of eighty or more inhabiting the archipelago, a fraction which wantonly attacked the American troops in Manila while in rightful possession under the protocol with Spain awaiting the ratification of the treaty of peace by the Senate, and which has since been in active, open rebellion against the United States. We are asked to transfer our sovereignty to a small minority in the Islands without consulting the majority and to abandon the largest portion of the population, which has been loyal to us, to the cruelties of the guerrilla insurgent bands. More than this, we are asked to protect this minority in establishing a government, and to this end repress all opposition of the majority. We are required to set up a stable government in the interests of those who have assailed our sovereignty and fired upon our soldiers, and then maintain it at any cost or sacrifice against its enemies within and against those having ambitious designs from without."

While President McKinley was thus proclaiming to the American people that American sovereignty was being joyfully received by the 
majority of the Filipinos, Mr. Roosevelt, the vice-presidential nominee, on the other hand, was drawing graphic pictures of Filipino civilization. "The reasoning which justifies our having made war against Sitting Bull," he said, "also justifies our having checked the outbreak of Aguinaldo and his followers, directed, as they were, against Filipino and American alike. . . To grant self-government to Luzon under Aguinaldo would be like granting self-government to an Apache reservation under some local chief." These words were not made on the mere spur of the moment at some political mass meeting. They are to be found verbatim in Mr. Roosevelt's carefully prepared letter of acceptance of his nomination as Vice-President.

During the ratification of the Treaty of Paris in the Senate, Congress refused to disclose its purpose towards the Islands because such would be "giving bonds to Spain" on a matter that was "wholly their own to decide" and not Europe's. The ratification of the treaty concluded, attempts were again made to secure a definite declaration of policy on which to base an equitable Filipino-American relationship. Unfortunately the Filipino-American War had broken out and this afforded a new excuse for the re- 
tentionists. "We will not tell the Filipinos what we want to do with them until they lay down their arms," was the argument they then advanced. Unconditional surrender was asked of the Filipinos in arms. Sheer exhaustion was the only thing, however, which brought about such unconditional surrender and complete peace.

With the laying down of their arms the Filipinos did not thereby cease their protest against American sovereignty. The work of emancipation was renewed with the implements of peace. The national spirit that had animated them on the battle-field was soon reawakened; and the political party that had adrocated permanent annexation was relegated to oblivion. In 1902 Congress took up the question of establishing civil government, and once again attempts were made to bring about a statement of policy, but to no avail. The law that was passed in that year was merely "an act temporarily to provide for the administration of the affairs of civil government in the Philippine Islands." It was temporarily imposed upon us for fourteen years.

The Filipino people then carried on a persistent but peaceful campaign, petitioning the 
American people to recognize their right to independence and to define their ultimate political status; but no such definition of policy was forthcoming. The issue was never squarely met by the only authoritative body which could decide it, the American Congress. By virtue of the Organic Act of 1902 the people of the Philippines were allowed to send two Resident Commissioners to Washington. Everybody knows what the work of these representatives has been. They became the mouthpiece of Filipino aspirations for independence. They told the American people that the Filipinos did not want to remain under American sovereignty, that they desired to establish a government of their own which would be more satisfactory to them than any American government could be. They further told them that American retention of the Philippines was a continuous violation of the American principle that all governments derive their just powers from the consent of the governed.

No other position could have been taken by the Filipino people compatible with their dignity as a people than that of carrying on an independence campaign and reasserting their rights as a nation. No more effective claim to the just 
consideration of the world could have been brought than their solemn protest against the continuation of American sovereignty in the Islands in spite of the benefits they were deriving from such an occupation. Had they been a mere conglomeration of savage tribes devoid of any national consciousness, how easily could they have accepted American rule, forgotten their forcible subjugation, and borne in mind only the material and social improvements brought about under American occupation! For the very reason that they are a people jealous of their national honor and rights, they failed to be satisfied with the benevolent enterprises of the American Government; they saw behind all exterior manifestations the baffling of their national aspiration, the usurpation of their right to an independent existence. Such a position undoubtedly helped the American people to see the wrong in buying sovereignty and forcibly imposing it over an unwilling people.

Let it be said, however, in justice to those who are responsible for the acquisition of the Philippines that, in spite of the lack of mutual understanding between the American and Filipino peoples which existed for many years and the failure to recognize the right of the Philippines 
to independence, the policy of extending step by step the governmental powers to the Filipino people was adopted with the welfare of the people as the sole end in view. Even before the complete restoration of peace schools were established, public improvements were undertaken, and sanitary measures adopted for the up-building of the Filipino race. Freedom of speech, of the press and of thought were declared to be inviolable rules, and thus the American Government, instead of stifling the political aspirations of the people and making them forget their idea of independence, or compelling them to keep it within their breast, has given them a greater consciousness of kind, has united them into a more responsive whole, and has encouraged them to demand with greater insistence an independent national existence. As soon as civil government could be established in the Islands President McKinley made it the fundamental aim of the American Government " to improve the condition of the inhabitants, secure them peace, liberty, and the pursuit of their highest good."

President McKinley's governmental policy was later on interpreted by Mr. Taft as a policy which " must, logically, reduce and finally end the sovereignty of the United States." The Repub- 
lican leaders, after the death of President McKinley, openly stated that the American purpose toward the Philippines unequivocally contemplated the political separation of the Islands. Mr. Root, at the Republican Convention of 1904, suggested that the Philippines in due time might have the same status as Cuba. President Roosevelt in 1908 hoped that within a generation the Filipinos could decide for themselves "whether it is well for them to become independent or to continue under the protection of the United States." Mr. Taft, who implanted civil government in the Philippines, was even more explicit in his promises to the Filipino people. As Secretary of War he said that "when the Filipino people, as a whole, show themselves reasonably fit to conduct a popular self-government, maintaining law and order and offering equal protection of the laws and civil rights to rich and poor, and desire complete independence of the United States, they shall be given it." These statements by Mr. Taft while Secretary of War were confirmed by him as President of the United States when in an official message to Congress he said: "We should endeavor to secure for the Filipinos economic independence and to fit them for complete self-government, with the power to decide 


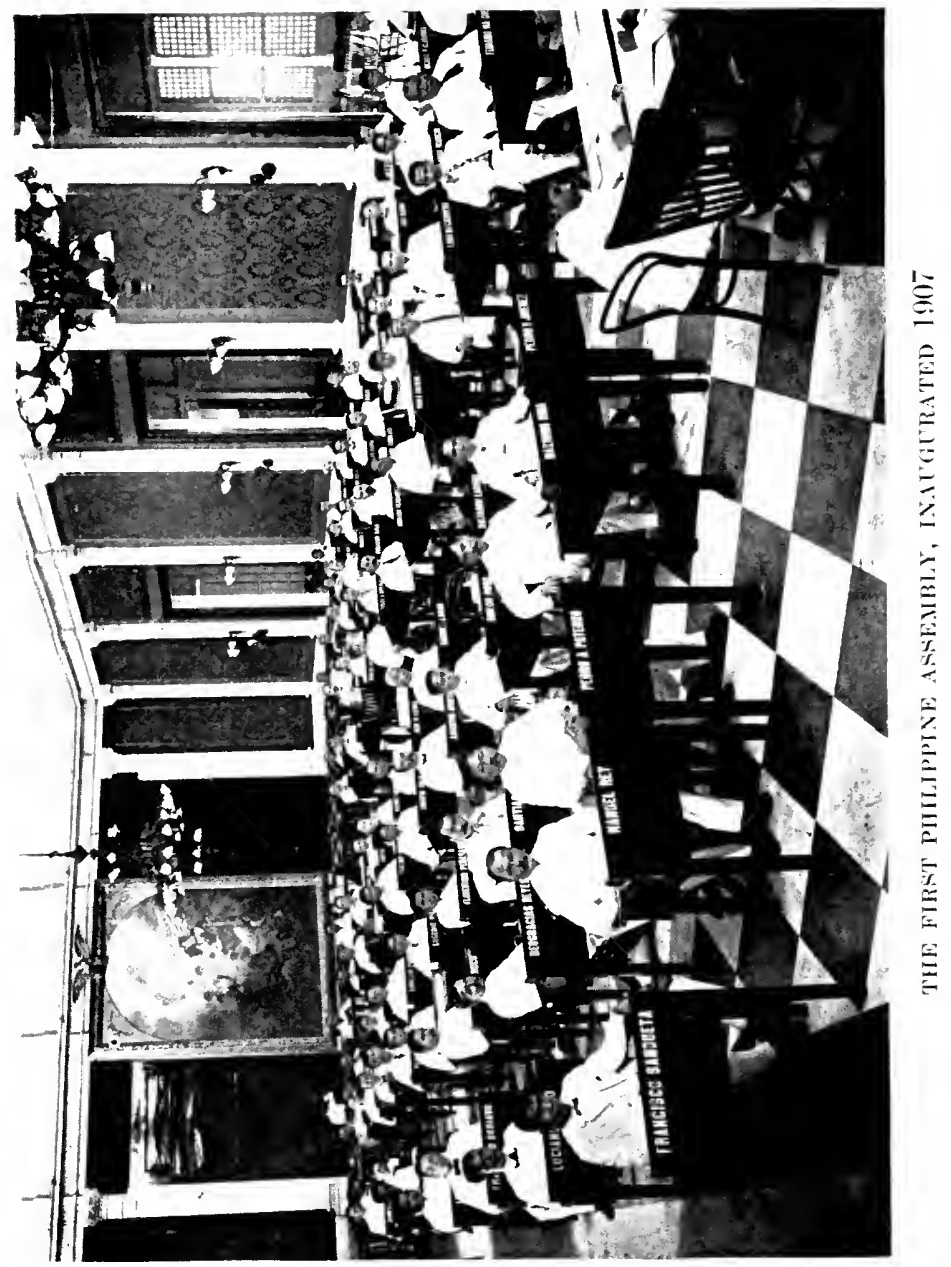




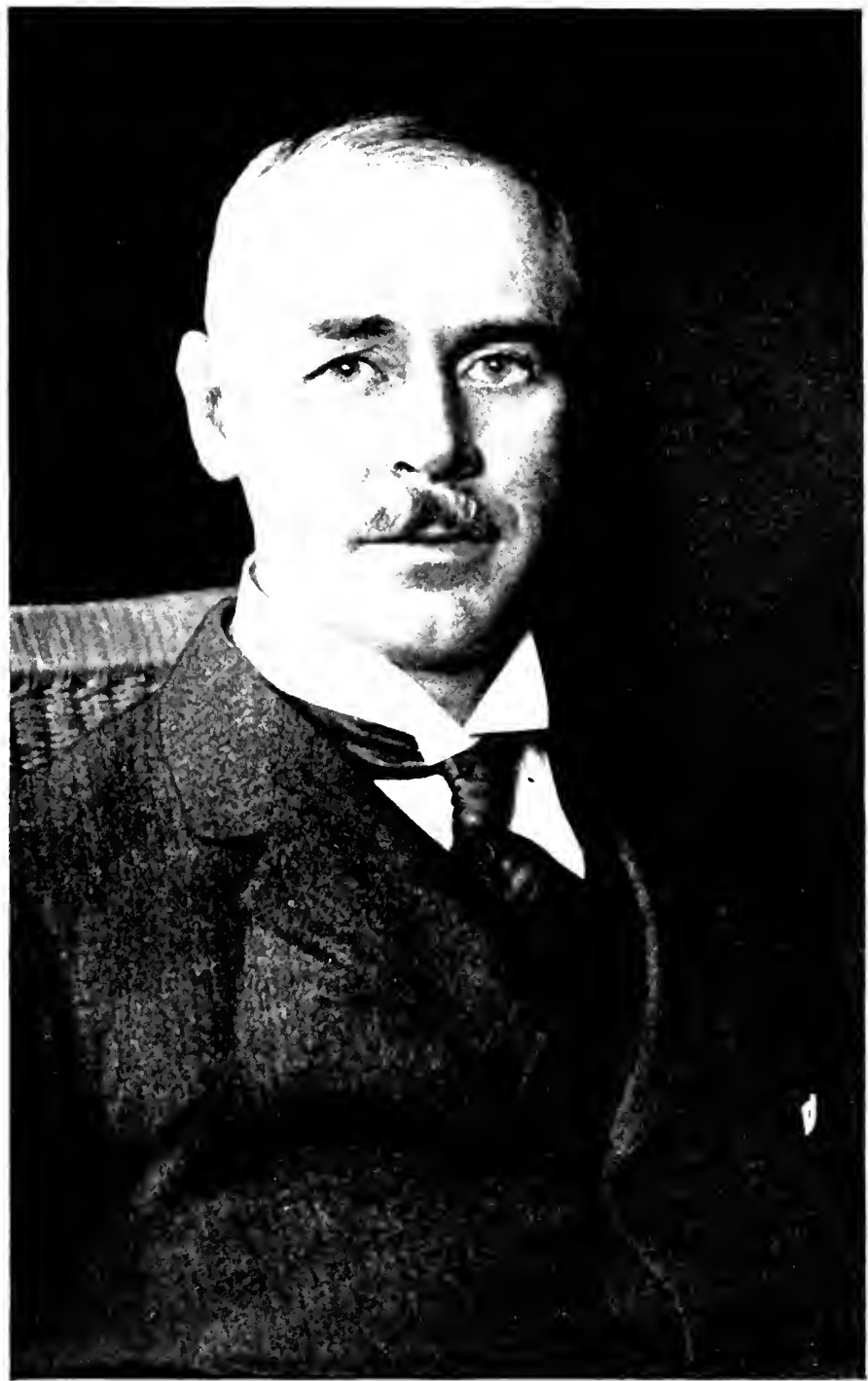

Photomaph by Interational Fila sicruce

THE HONURABLE FRAYTIS BITTON HARRISON

Governor-cieneral of the Philippines sines 1913 , under whose administration practical solf-government has been established in the Islands 
eventually, according to their own largest good, whether such self-government shall be accompanied by independence."

These statements of responsible executive officials of the American Government were very gratifying to the Filipinos; but, as they were not satisfied to wait a generation for independence, no full and complete understanding was obtained between the two peoples. Besides, these promises were merely statements of executive officials which must be ratified by the American Congress before they could be made a real pledge of the American people to the Filipino people.

President Wilson came nearer securing the complete understanding with the Filipino people. Soon after he was installed in office he appointed a majority of Filipinos in the upper house of the legislature, thus giving them almost complete domestic autonomy, coupled with the definite assurance that the step was taken "with a view to the ultimate independence of the Islands and as preparation for that independence." "By their counsel and experience rather than by our own," says President Wilson, "we shall learn how best to serve them and how soon it will be possible to withdraw our supervision."

The complete understanding which brought 
about the most friendly relations between the two peoples came in the shape of the Jones Law, or Philippine Autonomy Act. The Jones Law in its preamble declared that " $i t$ is, as it has always been, the purpose of the people of the United States to withdraw their sovereignty over the Philippine Islands and to recognize their independence as soon as a stable government can be established therein." It was not a Democratic measure alone passed by a Democratic majority. It is true that in 1914 when the bill was first introduced, the Republicans were opposed to the preamble containing the promise of independence, although they were in favor of the legislative features of the bill. But in 1916 when a strong movement was initiated in the United States for the passage of a more radical measure, the so-called Clarke amendment, the Republicans also advanced their position and advocated a more liberal measure for the Philippines. They stated that they would accept the Jones bill introduced in 1914 which is practically the present Jones Act, only with more liberal provisions. In dissenting from the position of the majority in the House Insular Committee on the Clarke amendment, the Republicans on April 12, 1916, said that they " en- 
tirely agree with the majority that the Philippines should be given a new fundamental law granting to the people a larger measure of selfgovernment. They would even support the Jones bill with the preamble as a substitute for the Senate bill with the Clarke amendment."

In pursuance of such an attitude the Jones bill in exactly the same manner in which it passed that House in 1914 was repassed practically by unanimous vote. As is commonly known, the Senate had more radical tendencies toward the Philippines, for it had passed the Clarke amendment. The final Conference report was adopted by the two Houses practically without opposition, and thus we have the Jones Act of today. It is a measure approved by Republicans and Democrats alike.

The Jones Law had, therefore, the sanction of the entire American people as represented by their accredited representatives in Congress on the one hand and of the Filipino people on the other. For the first time in the history of American occupation was there an understanding reached between the two peoples. For the first time a legislative measure affecting FilipinoAmerican relationship received Philippine sanction. The Philippine Legislature had time and 
again petitioned for the enactment of the law. Resolutions after resolutions had been adopted by the Philippine Assembly asking for its passage if no more radical measure could be enacted. The Philippine Resident Commissioners had worked for the same thing. The Filipino people endorsed the measure in numerous public meetings, in resolutions passed by provincial boards and municipalities and ratified that endorsement when they returned the majority party in power.

American sovereignty in the Philippines has thus ceased to be without the consent of the governed. The Jones Law has become a virtual constitutional compact between the American and Filipino peoples, by means of which the Filipinos have accepted a temporary government under American sovereignty subject to the conditions; first, that it shall be autonomous, or chiefly in the hands of Filipinos; and, second, that it shall be only preparatory to a complete independence, such independence to be granted "when a stable government can be established in the Islands." It is, to quote the words of its author, the late Representative Jones, "the everlasting covenant of a great and generous people, speaking through their accredited rep- 
resentatives, that they (the Filipinos) shall in due time enjoy the incomparable blessings of liberty and freedom." "Henceforward," said the foremost spokesman of the Filipino people, Speaker Sergio Osmeña, in accepting the Jones Law on their behalf, "we can look upon the American flag not as the symbol of an imposed government but as the emblem of a nation whose temporary guidance over the Filipino people will serve as an instrumentality for the most speedy assumption of the responsibility of an independent life." 1

1 For a fuller discussion of past Filipino-American relations, see the author's other volume, "The Case for the Filipinos" (Century Co., 1916). 


\section{CHAPTER II}

THE ORGANIZATION OF THE NEW GOVERNMENT

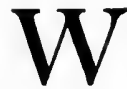

THEN the American Government decided for the first time to try the experiment of colonial government in the Philippine Islands, they had no light to guide them save the experience of other European nations which had colonies in Far Eastern Asia. Ignorant of Philippine conditions, the American statesmen at first thought that the problem of governing the Islands was similar to the task of the European powers in governing our neighbors, Java, the Malay States and India. Their first idea was, therefore, to study the colonial systems of these countries. One of the first public documents printed by the American Congress in 1899, accompanying the Treaty of Paris, was devoted to the study of the colonial systems of the Orient for their application in the Philippines. But upon a closer observation of Philippine conditions they found that the principles of European colonization would not work in the 
Islands, not only because American aims were more altruistic but because political conditions were entirely different. Roughly, colonial government in our neighboring countries is based on the existence of native rulers, rajahs or princes, whose authority has been for centuries recognized by the natives themselves. Apparently and ceremoniously the native princes still rule, but in reality it is their respective European "advisers" or " resident-generals" who are the actual rulers. Instead of establishing a new form of government, abolishing the rajahs and native rulers, the Dutch and the English simply improved the native institutions, using these same rulers as instrumentalities through which to impose their own will.

Now these conditions do not exist, and have not existed in the Philippines for more than two hundred years. The greatest political service of Spain to the Philippines was the abolishment of this native system of government and the extinction of royal or princely families. The establishment of Christianity in the Islands sowed the first seeds of equality and democracy, and the centuries of Spanish domination completely effaced from the Christian population all blood and family distinction. 
Upon the coming of the Americans, the Philippines had at least a system of local government by suffrage, howerer defective and limited in practice it was. The work of propaganda for reforms in Spain had brought to the front national leaders, recognized by all the Christian Filipinos not for their princely blood, for they had none, but for their unquestioned ability. The leadership and martyrdom of our national hero, José Rizal, was a proof that the Filipinos could look at some one man as a national guide and inspiration. They had long discarded the tribal conception of social organization. The establishment of a Philippine Republic, and the subsequent war with the United States, made it even more apparent that the people could establish a national government after the Occidental type. It was for these reasons that the American statesmen who had been studying the governmental forms of Java and the Malay States desisted from their original idea of applying this type of government in the Philippines. There was a potential democracy in the Islands.

Without belittling what America has done for the Philippines, there is no getting away from the fact that the progress towards democracy in 
the Philippines has been due mainly to the materials that America found there. This made America's task a great deal easier. That was why even the early military governors of the Philippines found no difficulty in continuing to a large extent the municipal government of the Islands, giving it a larger autonomy. The first local elections in the Philippines took place under the supervision of military officers. After the extension of municipal autonomy came the establishment of provincial government under a board composed of an elective governor and two other provincial officials appointed by the Governor-General. Following the popular demand, the provincial government was again changed and complete provincial autonomy was given under a provincial board totally elected by the people. The Congress of the United States, in passing the Organic Act of 1902, decided to call a National Assembly in 1907 to participate in the national law-making. Being the only representative governmental organ, this assembly became the exponent of the ideals and aspirations of the Filipino people. It represented their "counsel." While there were other Filipino officials in the upper house appointed by the President, the Speaker of the National 
Assembly was considered the leader of the people in the government. He was ostensibly at one and the same time representative of his district and also of the entire body which elected him. He represented more narrowly the "counsel" of the people. His rise in influence has been due, therefore, not so much to the fact that he was the presiding officer of the Assembly, but because he was the ouly man in the government who could truly be said to represent the people. The more a Governor-General wanted to make his administration popular, the greater became the power and influence of the Assembly, and consequently that of the Speaker. The Filipino people looked up to the Speaker for the success or failure of the part they were taking in the government. The Assembly typified all the ideals of the people, and every step towards a more liberal form of government was advocated and fought for by that body. It insisted that, being the popular body, it should initiate all appropriation bills. It also fought for the control of the Resident Commissioners in the United States. The law provided that the two representatives in Washington should be elected by the two houses, but inasmuch as the intention was to send representatives of the Filipino 
people and not of the administration and because the upper house was controlled by Americans, the Assembly argued that it should have the final say as to the choice of these men. There were continuous conflicts on other governmental matters between the lower houses and the appointive commission. Deadlocks were constant on the appropriation bills, the representatives of the people being solidly opposed to the financial policies of the American-controlled upper house. The provision in the law to the effect that in case of such deadlocks the total sum of the previous appropriation law would, upon the advice of the Governor-General, be considered appropriated for the ensuing year, left the popular chamber with very little financial power. Add to this the fact that the upper house, or the Philippine Commission, had exclusive jurisdiction over the non-Christian parts of the archipelago, almost one-third of the total area of the Islands, and we may know just how much power the Assembly had. The government then established, the mixture of a representative institution and an irresponsible executive and administration, was hence very unsatisfactory. That type of government has failed wherever it has been established. It failed in the early Eng. 
lish colonies, where, as in the Philippines, the lower house became the stronghold of the people, and the governor and his council the representatives of the crown. It failed in Canada, where, because of threatened separation from the Mother Country, the system had to be completely abolished and a responsible government established - a government wherein not only the lower house is subject to the people's call, but also one in which the chief executive merely acts as a passive and ceremonial figure, leaving all governmental affairs in the hands of a select body, the cabinet, responsible to the people or their representatives.

But though the power given the Filipinos in the old régime was limited, there was an advantage in the system in that there was unity of leadership among the members of the Assembly. Besides the leadership assumed by the Speaker, the internal organization of the Assembly also made for unified action. While the house was, like the American legislatures, split up among many committees, there was a "committee of committees," so to speak, the committee on appropriations, composed usually of chairmen of other committees, to which all matters touching revenues and expenditures were referred. There 


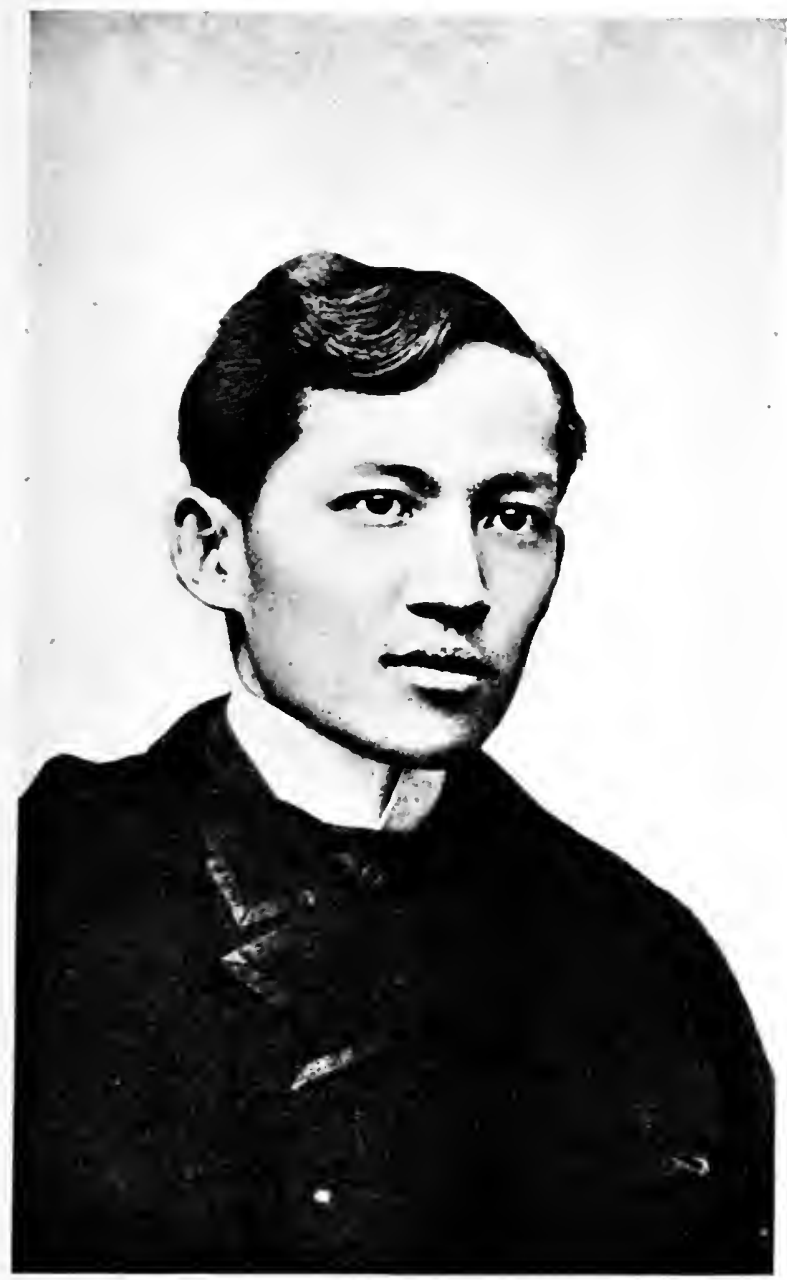

JOSÉ RIZAL

The national hero of the Philippines 


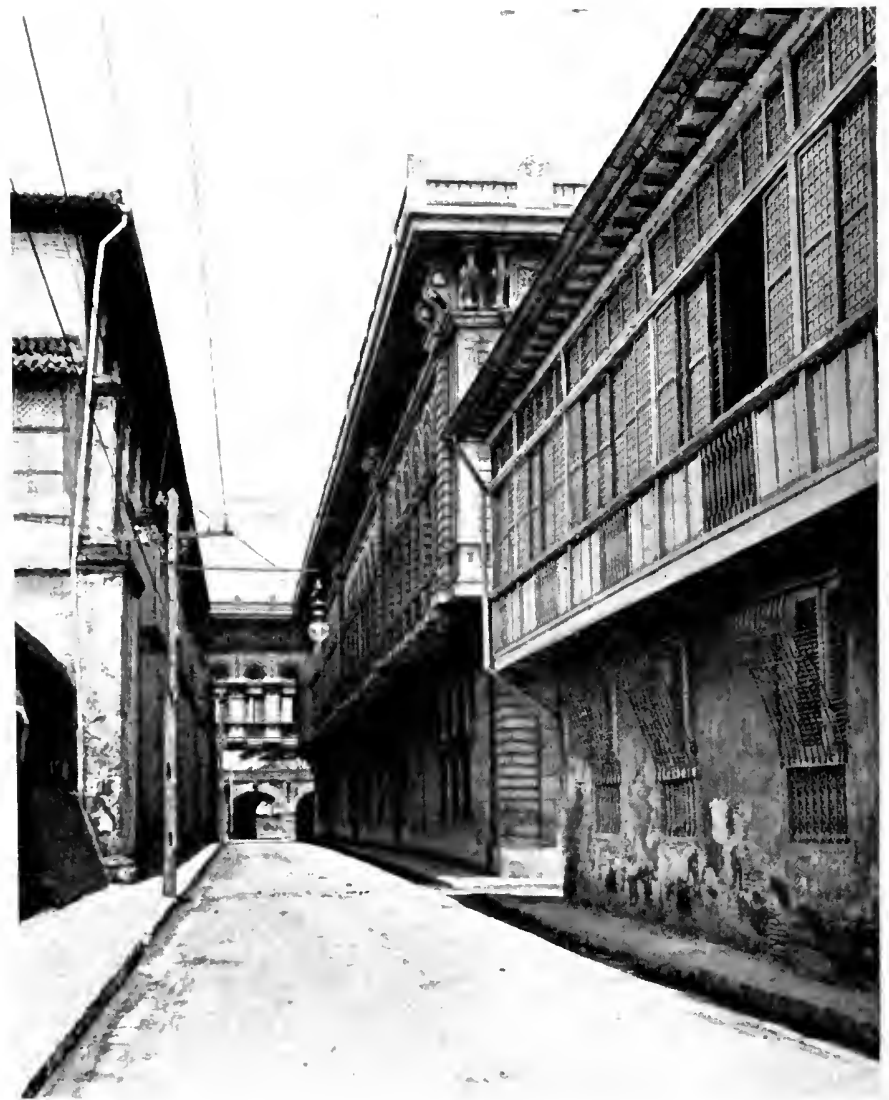

A GLIMPSE OF PORTION OF OLD MANILA 
was, therefore, no confusion of counsel. Even after the majority of the appointive commission became Filipinos, the Assembly retained the confidence of the people, so that when a democratic administration came with the desire to give the people more power, the problem of popular government in the Islands, in so far as it could be possible within the limitations of the then Organic Act, was relatively simple: there was but one real leader of the people, and that was the Speaker of the Assembly. Governor-General Harrison had naturally to call on him and other recognized leaders of the Assembly for advice on governmental matters. The Governor-General thus became a sort of constitutional monarch in the Philippines, listening to his responsible advisers on governmental questions; or, better still, he approached more the type of the English governor of a self-governing colony ruling upon the advice of the local cabinet.

The coming of the Jones Law made the problem of popular government in the Islands, in a way, more difficult. Being a complete constitution made by an alien people, outlining a framework of government for another people, ten thousand miles away, living a different life and nourished by different political traditions, its 
practical application presented some very serious problems. The solution of these problems by the Filipino people would in itself indicate the grade of political capacity they have attained. The fundamental defect of the Jones Law consists in the fact that the Filipinos were granted and told to work out a complete system of government in the framing of which they had but a very small, if any, share. Under the Jones Act, besides the Philippine Assembly, two other governmental instruments or powers were given the Filipinos: to the lower elective house was added an elective senate, and the Philippine Legislature was given the power to reorganize the executive departments, with the exception of the Department of Public Instruction. There were at first conflicting opinions as to how large a portion of the executive function was meant to be given the Filipinos. Would the Filipino executive heads appointed by the Governor-General, with the consent of the Senate, be responsible to the people or to their representatives? It is true that their appointment, like all others made by the Governor-General, requires the consent of the Philippine Senate; but under the American Federal system the President's cabinet is also appointed with the consent of the 
Senate of the United States, and yet American cabinet members are in reality mere agents of the President. They are not responsible to Congress, and the Senate's consent simply comes as a matter of form. The executive power being vested in the President, and there being, legally at least, complete separation between the executive and the legislature, all executive officials are in reality simply his agents. The executive power under the Jones Act is, as in the American Government, vested in the Governor-General. Therefore, in the opinion of some, it was more than likely that the heads of the executive departments would be mere agents of the Chief Executive.

But the liberal constructionists triumphed. We must get the answer from the spirit and purpose of the act, they said. The purpose of the act is to give to the Filipinos as large a control of their affairs as can be given to them without impairing the rights of sovereignty of the United States. The mere giving of two branches of the legislature would not make our government an autonomous one if the people were not given a hand in the execution of the laws and in the administration of the government. Considerable executive power must, therefore, be given to 
the people. This interpretation was supported by Governor Harrison in a statement given on September 1, 1916, in which he explained the meaning of the bill. He said :

"The main points of opposition to the bill centered upon the promise in the preamble of ultimate independence, and the power of confirmation of cxecutive nominations by the Philippine Senate. So far as my own personal efforts could be of any influence, these were the two points upon which the greatest insistence was laid. With the support of the President and the work of friends in Congress, both questions have been resolved favorably. I am a firm believer that an executive should consult the people, through their representatives, as to who shall serve them in office. This is the vital nerve of self-government. It should never be possible, and it will now never be so here, for an executive to ride ruthlessly over the people he is sent here to govern, without due regard for their sentiments and due consideration of their wishes."

Inasmuch as our cabinet members are not elected by the people, they must be appointed only after consultation with our legislature, "the representatives" of the people. If that be the case, then a certain amount of responsibility of the cabinet to the legislature and indirectly to the people is assured. Credit must be given Governor Harrison for the splendid manner in 
which he has carried out the spirit of the Jones Act.

The Filipinos were, therefore, to have under their control three important and distinct in. strumentalities of government: to the lower house or Assembly granted us in our Organic Act of 1902 were added the Senate and the executive posts, except the secretaryship of Public Instruction. The organization of the new government brought forth several serious problems. These three organs of government, two legislative and one executive, must collectively possess, for their proper and efficient operation, first, harmony of action, and, second, effective responsibility to the people. These qualities should exist in all governments, but particularly in a governmental organization still dependent on a foreign flag. While we remain under American sovereignty we must have complete harmony of action and community of purpose in all the governmental organs that may be given us; and, lest these organs be used arbitrarily, they must be made amenable to public opinion and responsible to the people. How could this be done? When we had only one organ for expressing the people's will, the Philippine Assembly, and a new Governor wanted to use this 
organ so that he might govern with the sanction of public opinion, it was easy to place the responsibility on the Speaker of the Philippine Assembly. He was, as one editor graphically described him, at the head of the Philippine Government on behalf of the Filipino people. Who was to take that place under the new management? Should he be the Speaker of the Assembly as before? And how about the President of the Senate? And the heads of departments? How was the collective counsel of the people to be represented? Who was the Filipino power in the government who, by virtue of his representation, was entitled to be first heard on important state affairs? Who was the man to be mainly responsible for the failure and success of the Filipino part in the government?

One of the political teachings of the recent war seems to offer a solution of the very problem which vexed the Filipinos in the organization of the new government. The critical war period, as well as the present era of reconstruction where tremendous problems must be solved, seems to point out the necessity of a more unified and responsible leadership on whom the initiation and responsibility for governmental measures should fall. How often has the United 
States appeared weak and vacillating before Europe, because of the extreme separation and independence between the legislature and the executive, the dislocation of responsibility for governmental policy, and the constant rivalry between the President and Congress!

In the Philippines one thing was found necessary: there must be harmony and cooperation in the control of the executive and the legislative departments given the Filipinos. Our legisla. ture is the immediate representative of the people, and, unless we decided to make our departmental heads elective at large, we must make them directly responsible to our legislature, so that they could in turn be made responsible to the people. This is in truth at variance from the American system of the complete separation of the executive from the legislative departments; but there is an excuse in America for such a separation, and that is the responsibility of the chief executive to the people. The secretaries of departments are responsible to him directly and not to Congress, for he is in turn directly responsible to the people. The peculiar situation in the Philippines demanded the adoption of another system. The Governor-General still remained an American, a representative of 
a foreign government and sovereignty, and responsible to America and not to us. If there were to be checks and balances among the political powers of the Philippines, they should be ex: ercised by the Governor on the one hand and the Filipino element on the other.

With the inauguration of the Philippine Legislature on October 16,1916 , the governmental machinery brought over by the Jones Act actually began functioning. Even in the early days of its organization, the absence of a legally united and responsible leadership was apparent. The two houses of the legislature were both elective, with co-equal legislative powers. The lower house, with its tradition dating from the inauguration of the Assembly ten years before, its brilliant record as the spokesman of the people, and the conflict it had waged with the Commission, together with its supposedly more popular character because of a shorter tenure of office, impressed its members with its importance. On the other hand, there was a new glamor in the name of Senate, and hence the people had from the beginning an instinctive feeling that somehow or other it was a more important body. President Quezon, in his inaugural address, referred to the popular character of the Senate, 


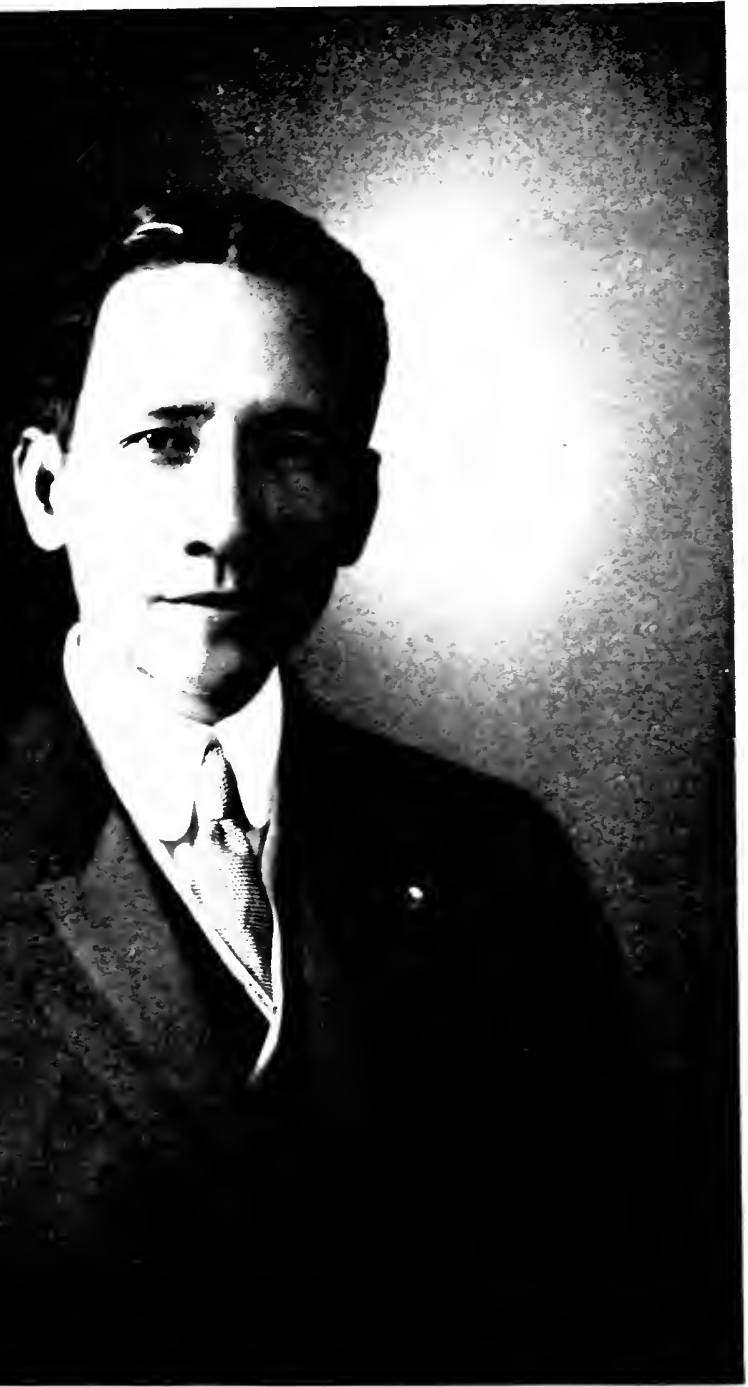

HON. SERFIO OSMENA

Speaker of the Philippine House of Representatives and Vice-President of the Council of State of the Philippine Government 


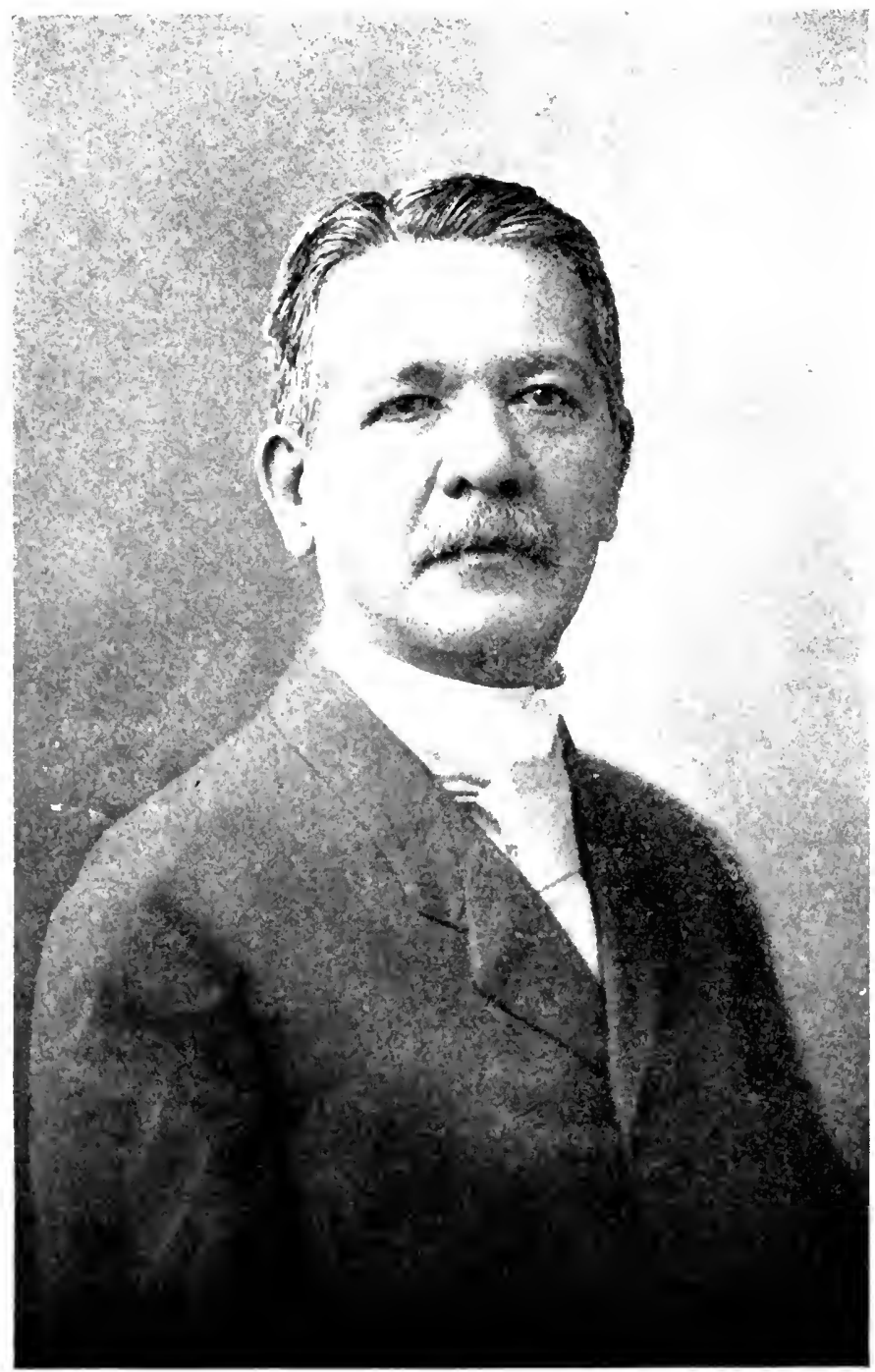

THE HONORABLE CAYETANO ARELLANO

Chief Justiee of the Philippine Supreme Court 
intended to represent, so he claimed, the maturer judgment of the people. That there should be a rivalry between these two houses was only natural. Harmony and cooperation between the two bodies was, however, made possible by the presence of an extra-legal factor - the political parties. Caucuses were at once held by majority members of the two houses, and, because of the overwhelming majority of the Nacionalista Party, a party policy could be enunciated and followed. The President of the Nacionalista Party continued to be Speaker Osmeña of the lower house, and the Senators, for party discipline, had to follow his leadership.

In the meanwhile the question of reorganizing the executive departments had been taken up. The statement of Governor Harrison that he would consult the people's representatives in the selection of officials insured a certain measure of cabinet responsibility on the part of future executive heads. It was advocated that members of the legislature be allowed to hold departmental positions, and that the practice of ministerial responsibility to the legislature be followed. Some questioned the practicability of this plan, inasmuch as the Governor-General still had the supreme executive power as well as the 
appointive power. Senate President Quezon answered this objection, saying that "although under the Jones Act the secretaries will be responsible to the Governor-General, yet in the development of the system which we implant under this bill, the day will come when the secretaries shall, at least in part, be responsible to the Houses." " It has been deemed advisable," said Senator Palma, "to provide in the bill that it shall be the duty of the heads of the executive departments to appear in either House whenever called upon to do so, not only for the purpose of reporting upon their official acts and measures, but also to collaborate in the policy and in the preparation of the acts passed by the Legislature. This can only be done if the department heads are members of the Houses. The duty to appear in either House of the Legislature may not look like very much on paper, but in reality it signifies a great deal. The department heads will not only have to give the information required of them, but being often subjected to minute interrogation they will have to explain and defend their official acts. If the Houses can demand of them that they give an account of their official acts, they are responsible to the Houses, though ultimately responsible to 
the Governor-General. We cannot claim more under the provisions of the Jones bill."

The Reorganization Act retained the old Department of the Interior and created five executive departments: Public Instruction, Finance, Justice, Agriculture and Natural Resources, and Commerce and Communications. The executive heads are to be elected at the beginning of every legislature, which means that they are to be chosen from the triumphant party in the preceding election. They may be called by, and may voluntarily appear before, either House. Legislative members can be appointed to the cabinet.

There was at first the idea of placing Filipino leadership in the cabinet instead of in the chairmanship of either House, and giving some members of the legislature cabinet posts, but the prohibition against legislators occupying positions created during their term of office made only one cabinet position available, the secretaryship of the Interior. The Senate would not be represented in the cabinet if the portfolio of Secretary of the Interior was given to the House leader. So the plan of placing leadership in the cabinet was abandoned, and the real legislative leaders had to remain outside the cabinet and continued to be the presiding officers of both houses. The 
floor leader of the Senate, however, was appointed Secretary of the Interior, and the other cabinet members appointed were all friendly to and in harmony with the party in power in the legislature. The presiding officers of both houses, because of their personality and the prestige of their positions, continued to be the most influential men in the government and the Governor-General's chief advisers.

The problem of an open and responsible leadership thus remained unsolved. Although everybody knew that Speaker Osmeña was the Filipino power in the government, his influence was no longer due mainly through his official position, but because he was the president of the triumphant party. This was a bad precedent, for then anybody who could, by hook or crook, become the leader of the party in power would be the most influential man in the government, and we would have the same problem of government by irresponsible party bosses which infests some American states and cities. It was urgent that out of the different instrumentalities of government granted by the Jones Law to the people, a definite body be created or recognized to represent more narrowly the counsel of the people, to breathe harmony and efficiency into our legis- 
lative and executive departments, and that in that body or council a place be assigned to a Filipino leader who would stand at the head of the government on behalf of the people and who should be raised to that position by a triumphant majority through his undoubted leadership and the confidence he might command in the entire nation. In actual practice Filipino leadership was dispersed among cabinet members and the presiding officers of the two houses. They were the chief advisers of the Governor-General. They formed an incoherent group with only party discipline and loyalty to impel them to work for a harmonious action. To give a legal status to their function as advisers to the Governor-General, it was decided to constitute them into a Council of State "to aid and advise the Governor-General on public matters." The GovernorGeneral presides over the Council and allows it to elect a vice-president who, in the very nature of things, becomes the highest Filipino official in the government.

The Council of State promises to solve the problem of responsible leadership in the government. Composed as it is by the highest executive officials and the recognized legislative leaders, all of whom have been chosen with the ap- 
proval of the representatives of the people, the Council of State is bound to exercise considerable powers. It can properly direct the Filipino element in the government. It can harmonize the executive and legislative departments, while not being exactly at the mercy of the transient moods of the legislature, for there is no provision for its dismissal in case its policy is disapproved by the legislature. The Governor-General sees in it a responsible council on whom he can rely for advice on domestic questions. The system may perhaps be said to be a compromise between the English cabinet system and the American system. It probably approaches more nearly the Swiss Federal Government.

Speaker Sergio Osmeña was unanimously elected Vice-President of the Council of State by his Filipino colleagues. His intervention in governmental matters is therefore no longer secret and extra-legal, secured by virtue of his party leadership, but open and responsible, as the highest Filipino official in the government and the chief adviser of the Governor-General. The first action of the Council of State indicative of a new force in the Philippine Government was the recommendation that thirty million pesos be appropriated for free education - a crying need felt 
for many years. The recommendation was approved by the legislature, and a law was written on the statute book of the Philippines which will give the rudiments of instruction to every child of school age in the Philippines.

The Jones Law left the organization of our judiciary untouched. One of the most important contributions of American occupation to the future Philippine state is the establishment of an independent judiciary, the greatest bulwark of a government of laws. Our judiciary is composed of a Supreme Court, courts of first instance, and justice of the peace courts. The Chief Justice of the Supreme Court is a Filipino. While there is a majority of Americans in the entire membership, its personnel is not a political factor. It has fitly held itself aloof from purely political controversies, and has gained the popular respect and reverence it justly deserves.

The position of the Governor-General in the present Philippine Government is a peculiar one. The learned English scholar, Mr. Bagehot, in speaking of the English government, said that there are two parts in that government; one is the ornamental and ceremonial part, in whose name the government is carried - the King of 
England, theoretically an absolute ruler - and the other is the active part, the one which really rules, which directs the ceremonial part in practically all the governmental work that it does the House of Commons, through its cabinet. The Philippine Goverument, in a small way, is approaching a similar arrangement. The Governor-General, although retaining in law the absolute executive power, rarely acts on matters of domestic concern, except with the advice of the Council of State. The guide for this exercise of governmental power is the spirit and purpose of the Jones Law rather than its letter. The object of the law is, to quote its preamble, "to place in the hands of the people of the Philippines as large a control of their affairs as can be given them without in the meantime impairing the exercise of the rights of sovereignty of the people of the United States, in order that by the use and exercise of popular franchise and governmental powers they may be the better prepared to assume fully the responsibilities and enjoy all the privileges of complete independence."

We have referred to the law as a veritable constitutional compact between the American and Filipino peoples. During the discussion of the 
measure in Congress, our representative, the Honorable Manuel L. Quezon, expressed the views of the Filipino people as to the amount of autonomy intended in the law, in the following words: "Heretofore we have been the least and the last factor in Philippine affairs. Hereafter we shall be the first and most important factor. Heretofore things were done by the Philippine government not only without the consent but on many occasions against the strong opposition of the Filipino people. Hereafter nothing will be done without our consent, much less in defiance of our opposition." The Governor-General, in interpreting the measure, said that from now on "it should never be possible, and it would never be so here, for an executive to ride ruthlessly over the people he is sent here to govern without due regard for their sentiments and due consideration of their wishes."

The organization of the new government has been carried on in the light of the foregoing interpretations. That is why the Filipinos today enjoy domestic autonomy. The Council of State is composed of eight members, all Filipinos, except the Vice-Governor. To help the departmental secretaries in the discharge of their functions, under-secretaryships have been created, all 
filled by Filipinos. The departments have absolute control and direction over the government bureaus. The Legislature is completely in the hands of Filipinos. While the GovernorGeneral has a veto power on legislation, subject to appeal to the President of the United States upon a two-thirds vote of both houses, he seldom exercises this power.

Secretary of War Baker, who has departmental supervision over the Philippines, has truly remarked: "Gradually and without violence, the functions of government have been taken over by the people of the Islands themselves, leaving only the tenuous connection of the Governor-General." Governor-General Harrison himself admits that there is already a "stable and progressive government" in the Islands. America may declare the Philippines independent at any moment and immediately recall her representatives from the Islands, and no institutional change will be necessary to continue the work of government there. There is a governing machinery set up by the Filipino people themselves to which the governmental powers can be transferred. In that event the Filipino people would simply imitate what Connecticut and Rhode Island did upon the Declaration of 
American Independence; they would simply declare American sovereignty at an end, bid farewell to their governor, and continue for the time being their institutional life under their present government until, of their own accord and following the recognized American practice, they could summon a constitutional convention to draft the permanent fundamental law for the first really democratic republic in the Far East. 


\section{CHAPTER III}

THE PHILIPPINE BUDGET SYSTEM

NE of the first governmental reforms carried out by the Philippine Legislature after the establishment of an autonomous government under the Jones Law was a budget system. The movement originated in the Philippines, as neither the first Organic Act of the Philippines, the Act of 1902, nor the Jones Law, suggested the establishment of the system. And the system that was established under the Organic Act of 1902 was, from the standpoint of a responsible democratic government, even worse than any American system on the continent, for it completely took away from the representatives of the people their rightful share in the appropriation and disbursement of public funds.

The Organic Law of 1902 provided that all appropriations must be made by law. (Sec. 5, Par. 15.) This apparently gave the Philippine Assembly, established in 1917, co-equal power with the Philippine Commission in money mat- 
ters. But such is not the fact. The other provision that in case of a deadlock on an appropriation bill the entire sum appropriated the year before shall be considered as appropriated for the ensuing year (sec. 7, par. 3) gave the Governor-General almost dictatorial power in fiscal matters. He could create, and did create, offices in defiance of the opposition of the representatives of the people, and could dispose in whatever way he wished of all the money of the government so long as the entire sum did not exceed the sum previously appropriated. Thus while all other popular legislative bodies had the distinction of commanding and controlling all money bills, serving thereby as a great check upon the executive, our Philippine Assembly was deprived of this function and was, as a result, a considerably weaker body than most legislative assemblies.

Under the circumstances the budget system could not in any way have been established. There was no executive responsible, or who could be made responsible to the Filipino branch of the Legislature, and to whom the preparation of the budget could be entrusted. Nay, it was even more advantageous for the Filipino people to demand the principle of the Congressional 
system; the initiation of all money bills in the lower house. This demand after a long struggle with the Commission was gained, although with no great advantage, for there being constant deadlocks between the two houses on appropriation bills, the fiscal power remained practically in the hands of the Governor-General.

The procedure followed in the submission and preparation of estimates was similar to the American federal practice. Thirty days before the opening of each regular session, each bureau chief - not the department head - sent to the Executive Secretary, a statement of the receipts and expenditures of his bureau or office during the year and an estimate of the receipts and necessary expenditures thereof for the ensuing fiscal year. Like the Secretary of the Treasury of the United States, the Executive Secretary simply compiled these estimates and sent them to the legislature. He had no power of revision or coordination. There was no executive responsible for the fiscal plan of the government. It was the question of who had the greatest "pull."

Other bills appropriating money were introduced in a hit-or-miss fashion, following no systematized and unified scheme of national improvement. They were considered on their in- 
dividual merits, and not on a well-defined fiscal plan for the entire country. They were not based on any possible amount of revenue that might be gathered. Thousands of this kind of bills were introduced at every session. Had they all passed, the resources of the country for the next ten years would have been exhausted. We never knew whether we were expending more than we were earning. We never learned, even more or less definitely, whether we were running into bankruptcy or not. This was shown to be the fact when on the assumption of office by Governor Harrison, there were wide asseverations that the Philippine Government had been running headlong towards financial ruin. "For three years prior to 1913," says Governor Harrison in his first message, "the Government had expended from two to two and a half million pesos yearly in excess of its ordinary income, and in 1913 had expended more than 7,000,000 pesos in excess of such income." Seven million pesos in excess of our income! The fact had never been openly communicated to the people or their representatives.

That there was an unpardonable lack of systematized plan in our previous financial system can be easily seen in the number and nature of 
appropriation bills annually passed by the Philippine Commission and the Philippine Legislature. From April 3, 1915, to March 16, 1916, for instance, thirty-seven acts carrying a total appropriation of over $38,000,000$ pesos were passed. The list follows.

ACTS CARRYING APPROPRIATIONS PASSED BY THE PHILIPPINE LEGISLATURE, OR THE PHILIPPINE COMMISSION ALONE FROM APRIL 3, 1915, TO FEBRUARY 24, 1916.

Number of Act

1. No. $2519 \ldots \ldots$

2. " $2521 \ldots \ldots$

3. " $2523 \ldots \ldots$

4. " $2524 \ldots \ldots$

5. “ $2525 \ldots \ldots$

6. " $2526 \ldots \ldots$

7. “ $2529 \ldots \ldots$

8. “

9. “ $2534 \ldots \ldots$ $2531 \ldots \ldots 1,000$

10. " $2535 \ldots \ldots$

11. "

12. "
Amount Carried

\section{pesos}

12,000.00. . Lepanto trail.

2,500.00..Publicity for forest study in Agusan Valley.

$20,000.00$. Locusts and rinder-pest in Mountain Province, Nueva Vizcaya, Mindanao and Sulu.

$15,000.00 .$. Roads and bridges in Nueva Viscaya.

$10,000.00$..Cholera in Mindanao and Sulu.

$35,000.00$. Agriculture, in d u s t r y, health and irrigation in Mt. Province.

$10,000.00$. For Baguio fair.

000,000.00 . Education in Non-Christian parts.

Not fixed..For destruction caused by baguios.

$15,000.00$. For repairs in Benguet road.

2540....25,468,913.31. General appropriation bill. 2542 .... 52,000.00..R e p a ir Naguilian-Baguio road for 1916. 


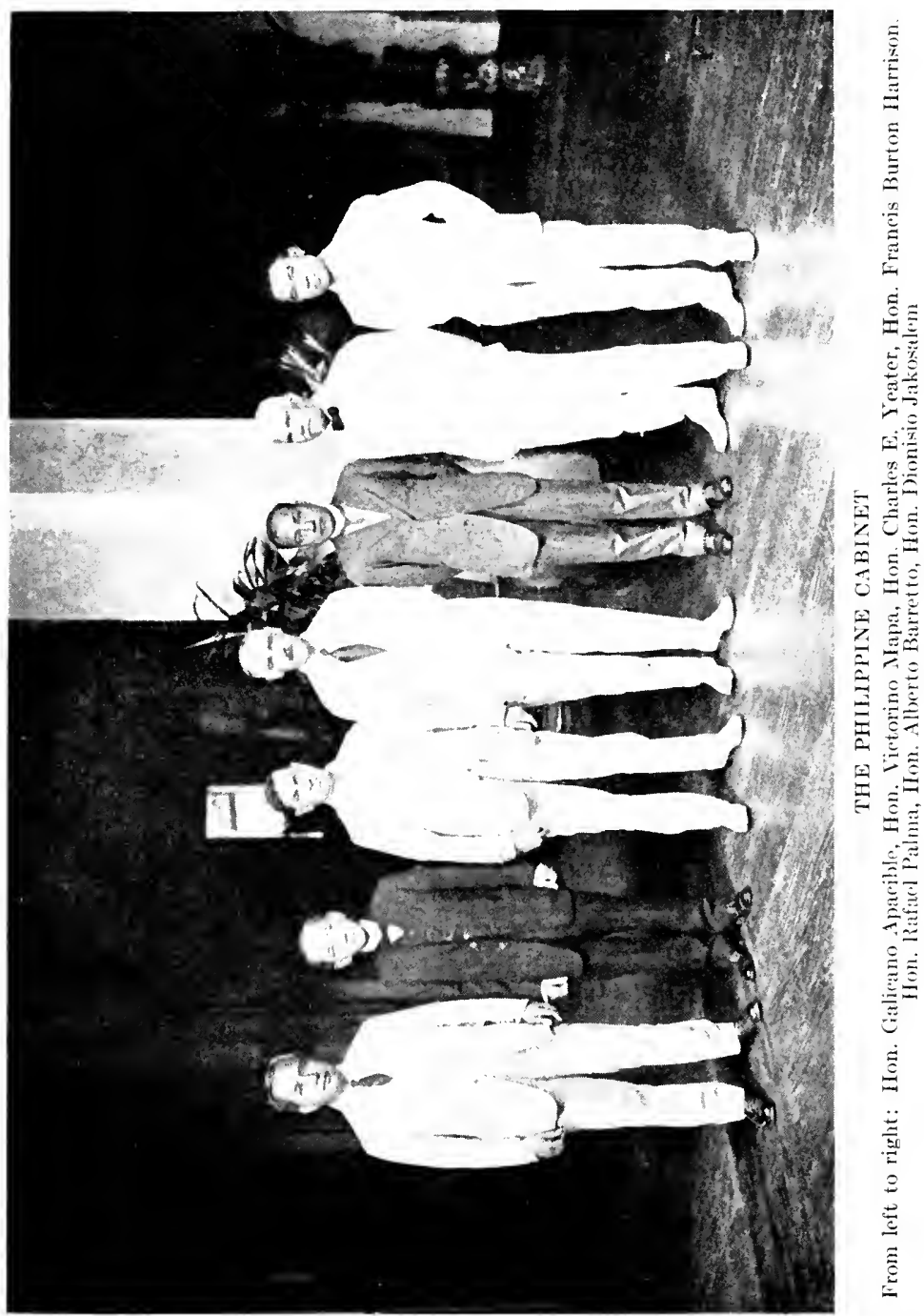




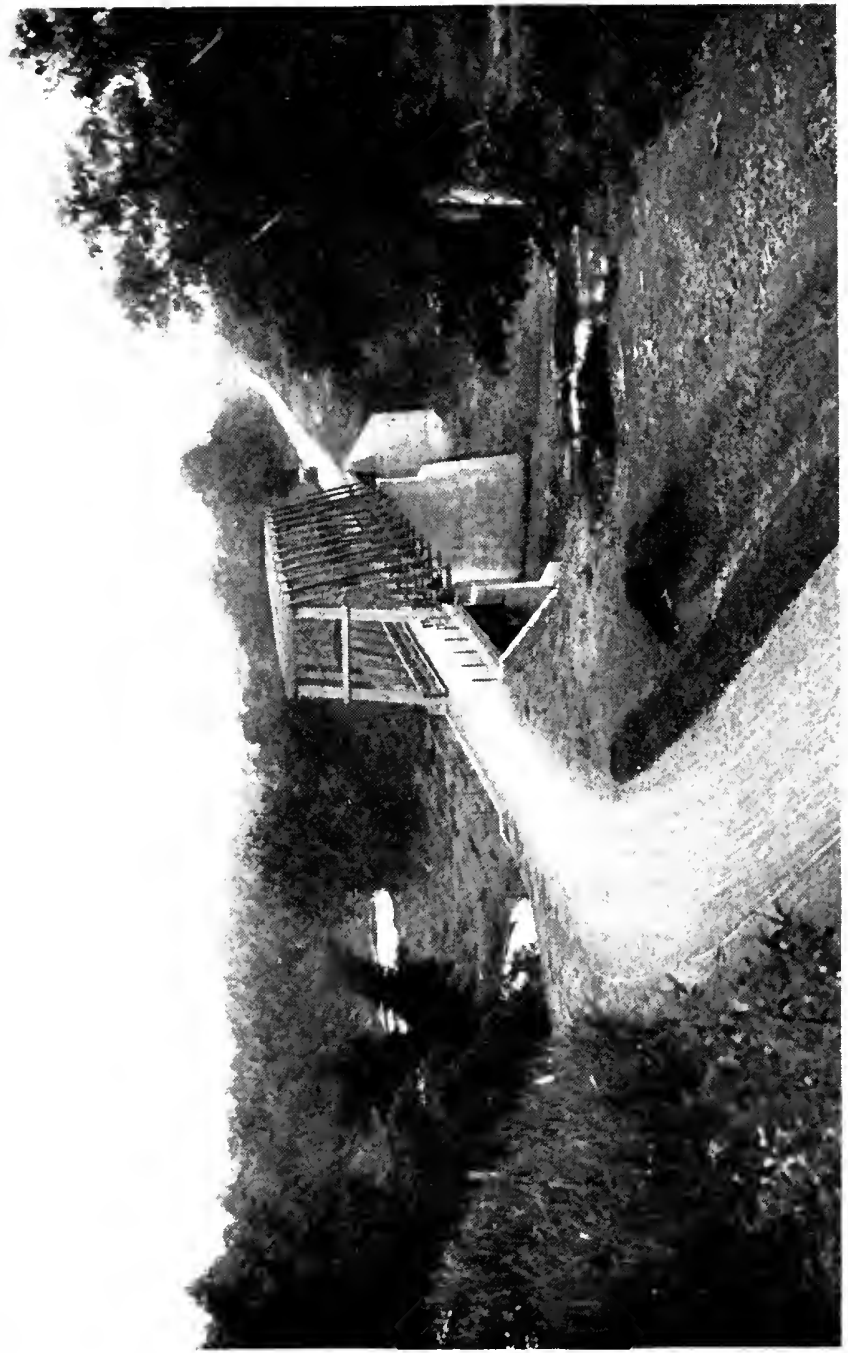

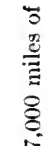

5

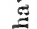

을

可.

正总

동

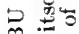

急

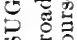

on

艺 $\stackrel{\varrho}{ \pm}$

息

¿ $\Xi$

Z O

$\leq \frac{9}{2}$

द

m

资

0 응

되 클

c

要

两

논

플

3

․․

$0 \stackrel{\vec{z}}{\overrightarrow{\tilde{J}}}$

约

政

a

○.

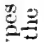

3

- 
Number of Act Amount Carried
pesos
Object

13. No. 2543..... 1,458,491.00 . Appropriation for Mindanao and Sulu.

14. “ $2546 \ldots \ldots$. 16,000.00. For Hotel Pines, Baguio.

15. “2547.... 269,311.11..Current expenses for Mt.

Province and Nueva Viscaya.

16. “ $2548 \ldots \ldots 50,000.00$..For immunization.

17. “ $2550 \ldots$. Not fixed..For obligations on account of friar lands.

18. " $2575 \ldots \ldots 2,2,000.00$. For creation of fiscalship in Palawan and other purposes.

19. “2583...2 2,621,000.00 . Permanent improvements.

20 . “ $2596 \ldots \ldots \quad 100,000.00 \ldots$ Aid to young industries.

21. " 2598..... 10,000.00..For "Junta de Productos del Coco."

22. “ 2607.... 2,500,000.00..Deposits in Commercial Bank for agricultural loans.

23. “ $2610 \ldots \ldots$ 49,145.00..Judiciary deficiency bill during 1916.

24. “ $2611 \ldots \ldots$ 118,882.59. . Deficiency bill for other governmental offices for 1916. (Total deficiency 168,027.59 pesos.)

25. “ $2612 \ldots \ldots 2,300,000.00$. Part payment for Nat'l Bank.

26. “ $2613 \ldots \ldots \quad 15,000.00$. Foment of tobaceo.

27. “ $2623 \ldots \ldots$.... 10,000.00..Conservatory of Music.

28. “. 2624.... Not determined. .To pay interest on bonds.

29. “ 2625 .... Not determined. . For amortization of bonds.

30. “ $2632 \ldots \ldots$. 7,500.00..For schools in Mountain Province.

31. “ $2633 \ldots \ldots 1,000,000.00$. To combat infant mortality. 32. “ $2637 \ldots \ldots$ 10,000.00. Exhibition at Formosa.

33. " $2638 \ldots \ldots$... $71,000.00$.. "Reimbolso" of land taxes in typhoon-devastated provinces.

34. “ $2649 \ldots \ldots \quad 10,000.00$. For forest reserve purposes. 35. " $2651 \ldots \ldots 25,000.00$.. For immunization. 
Number of Act

36. No. $2652 . \ldots$

37. “ $2659 \ldots \ldots$

\section{A mount Carried}

pesos

\section{Object}

Not fixed..Loans for irrigation purposes.

2,250.00..For police quarters, Mt. Province.

Total......38,341,993.01 pesos.

The table of laws shows a lack of systematized groupings of objects for the easy comprehension of the public or the legislature. At the end of every session a member could not know what had been the main fiscal policy of the legislature. Appropriations for social improvement or economic development are in several and independent bills. Act 2523, for instance, appropriates 20,000 pesos for extermination of locusts and rinderpest in the Mountain Province, Nueva Vizcaya, Mindanao and Sulu; Act 2526 sets aside 35,000 pesos for agriculture, industry, health and irrigation in Mountain Province; Act 2548 provides 50,000 pesos for immunization; Act 2598 gives 10,000 for Junta de Productos del Coco; Act 2613 appropriates 15,000 pesos for the foment of tobacco; Act 2651 adds 25,000 pesos to immunization funds provided in Act 2548; Act 2652 provides for loans for irrigation purposes. All these acts refer to the development of agriculture, and should be grouped together in one bill under that heading. They were undoubt- 
edly drafted by different persons who might not have the same ideas as to the way the agricultural development should be carried on. It is just as likely that some of these bills are at cross purposes with other bills on the same subjects.

Such was, in brief, the system of government finance in vogue prior to the establishment of the Jones Law. There was no attempt on the part of the Filipinos to adopt a budget system, for there was no responsible executive to frame it. All executive posts were filled by appointment by the President of the United States or the Governor-General without the consent of any representative body.

There was no centralized responsibility in the preparation and submission of estimates. Every little bureau was a department by itself, prepared its own estimate, and sent it to the legislature through the executive secretary. There was no coordination, each bureau trying to get as much as it could. There was no financial secretary to clip the wings of over-ambitious bureaus obsessed with self-importance. The result was an extravagant, top-heavy bureaucracy, an unnecessary duplication of work and activity.

But the coming of the Jones Law did not immediately solve the problem. As stated else- 
where, the Law did not provide for a budget system, and there were some who doubted whether it could be made possible under its provision. Sec. 21 of the Law states that - "The Governor-General shall submit to the Philippine Legislature within ten days of the opening of each regular session a budget of receipts and expenditures, which shall be the basis of the annual appropriation bill."

This provision and the fact that the GovernorGeneral still retained, according to law, supreme executive power, created in the minds of some the doubt as to whether the executive could be entrusted with the framing of the budget. The establishment, however, of a popular cabinet largely responsible to the legislature overcame the objection.

But there was another difficulty. Under Section 21 of the Jones Law referred to above, it is the Governor-General who is to submit a "budget of receipts and expenditures." Should he and not the cabinet draft the budget? In the latter case, the legislature might not be willing to give up its prerogative of preparing financial measures. Again, Governor-General Harrison came to the rescue, and following the generous spirit of the Jones Law, delegated to 
the cabinet the formulation of the budget. The old practice of having bureau chiefs prepare and submit their estimates was changed. Their estimates must now go to the Department head for revision. The Governor-General then in a message sends the budget as prepared by the Cabinet to the legislature for approval or rejection.

Before the preparation of the budget, a general line of policy is first agreed upon by the Cabinet in a meeting in which the presiding officers of both houses are also present. Once the general policy is agreed upon, a circular is sent in July to all offices and bureaus requesting them to send in their estimates which should include the probable receipts and the proposed expenditures for the coming year. These estimates are made under the supervision and control of the department heads who have the power to cut down or add items. These different estimates are then submitted by the department heads to the Secretary of Finance not later than August 20th, of every year. The main work of the Department of Finance is to coordinate the different departmental estimates in accordance with the general plan agreed upon at the Cabinet meeting. It often happens that a certain item submitted by a departmental head is already 
duplicated by another item from a different department. Any conflict between a departmental head and the Secretary of Finance is submitted to the Cabinet for the decision. The final budget is approved at the meeting of the Cabinet, at which the presiding officers of the houses attend.

The presence of the presiding officers in the cabinet meetings must be explained. The reason is that the two most prominent Filipino leaders in the government are not members of the Cabinet but are the presiding officers of both houses. In order therefore to fortify the position of the budget in the legislature, the informal concurrence of the presiding officers was necessary. This rather anomalous arrangement has been done away with, with the creation of the Council of State, composed of the Cabinet members and the presiding officers of both houses. Henceforward the budget will be made by the Council of State and not by the Cabinet.

Once the budget is definitely approved by the Cabinet, or by the Council of State, as will be the case in the future, the Governor-General submits it with a message to the legislature. The message is read by the Secretary of Finance in a joint session of the legislature. The lower house, by agreement with the upper, is the first 
one to take up the budget. It sets a date for the appearance of the Secretary of Finance to explain the details of the budget and to answer all questions propounded by the members. This appearance usually lasts five days and full opportunity is given the minority party to discuss the several items of the bill. To explain further the details of the budget, the individual departmental secretaries may be called, although this is not often resorted to, the Secretary of Finance generally assuming responsibility for the whole budget. It is the general rule in the discussion of the budget that the legislature may diminish the estimates, but may not increase them. Once the budget is approved in principle, it is sent to the Committee on Appropriations with instructions to draft the appropriation bill in accordance with the budget. This Committee again examines the different items of the budget, then frames and submits its appropriation bill. The Committee generally follows the instructions of the House and suggests in its bill only those changes that are absolutely necessary. Once the appropriation bill is approved by the House, it is sent to the Senate, where the Secretary of Finance again appears to explain the different items contained therein. 
The general tendency of the Senate is to act as a sort of arbitrator in the differences between the Cabinet and the House.

The financial plan of the executive or Council of State does not cover all the proposed financial activities of the government. In its plan it usually leares a surplus for the legislature to appropriate the way it pleases. This takes the form of new ventures and activities, like the recent creation of the National Development Company. The totality of the English budgetary principle is not, therefore, as yet followed, whereby all requests for money must come from the executive. But a long and decisive step had already been taken towards financial reform.

The system is conceded by friends and foes as a decided improvement over the old one. It is considered one of the greatest achievements of the Filipino people during the last three years of Philippine Autonomy. It has placed the Philippines, to use the words of Governor-General Harrison, "among the foremost progressive nations in fiscal legislation."

But it is not only the system of finance that has been changed and placed on a scientific basis. We may have the safest safe in the world, but if we have nothing to put in it, it would not help 


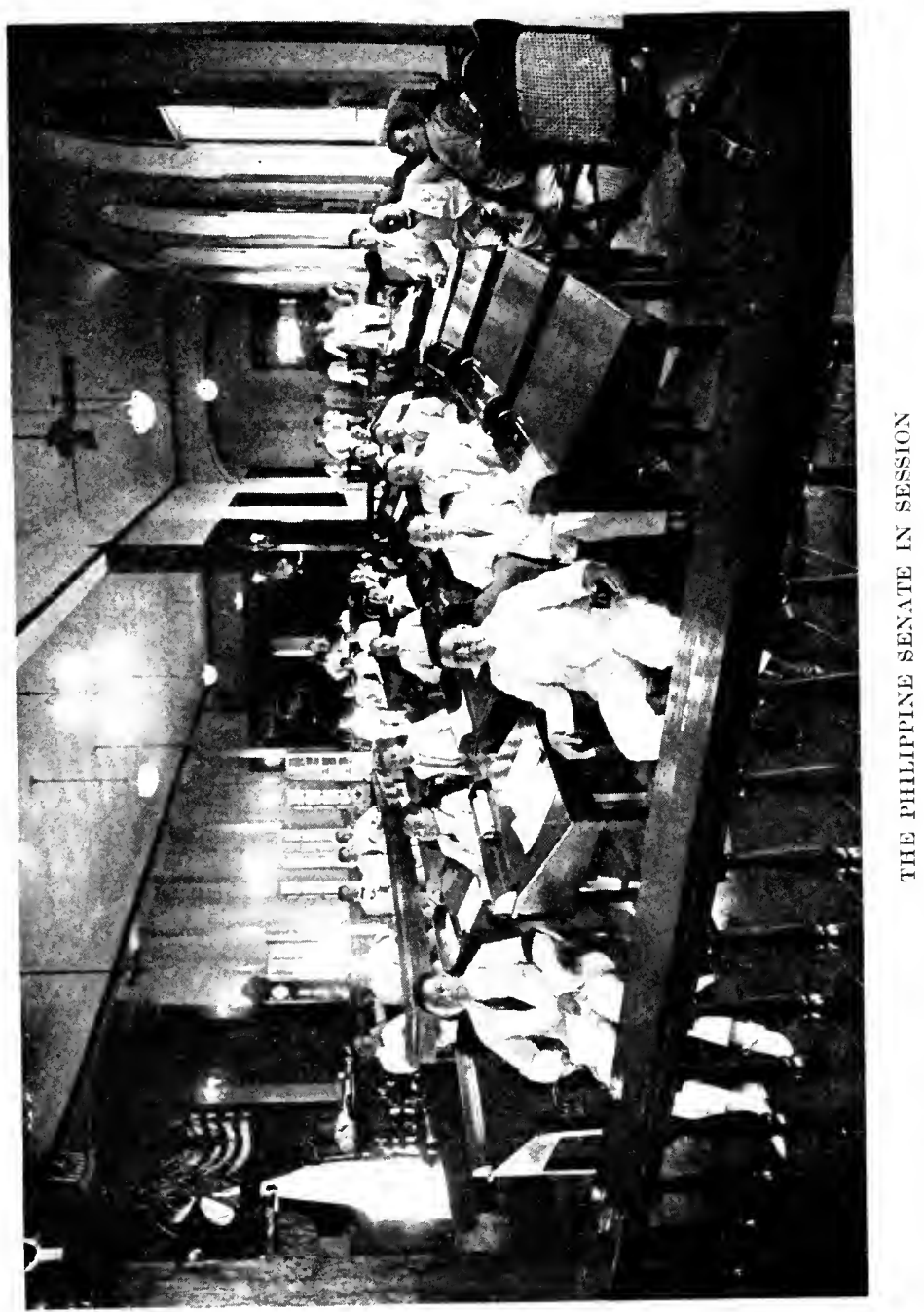




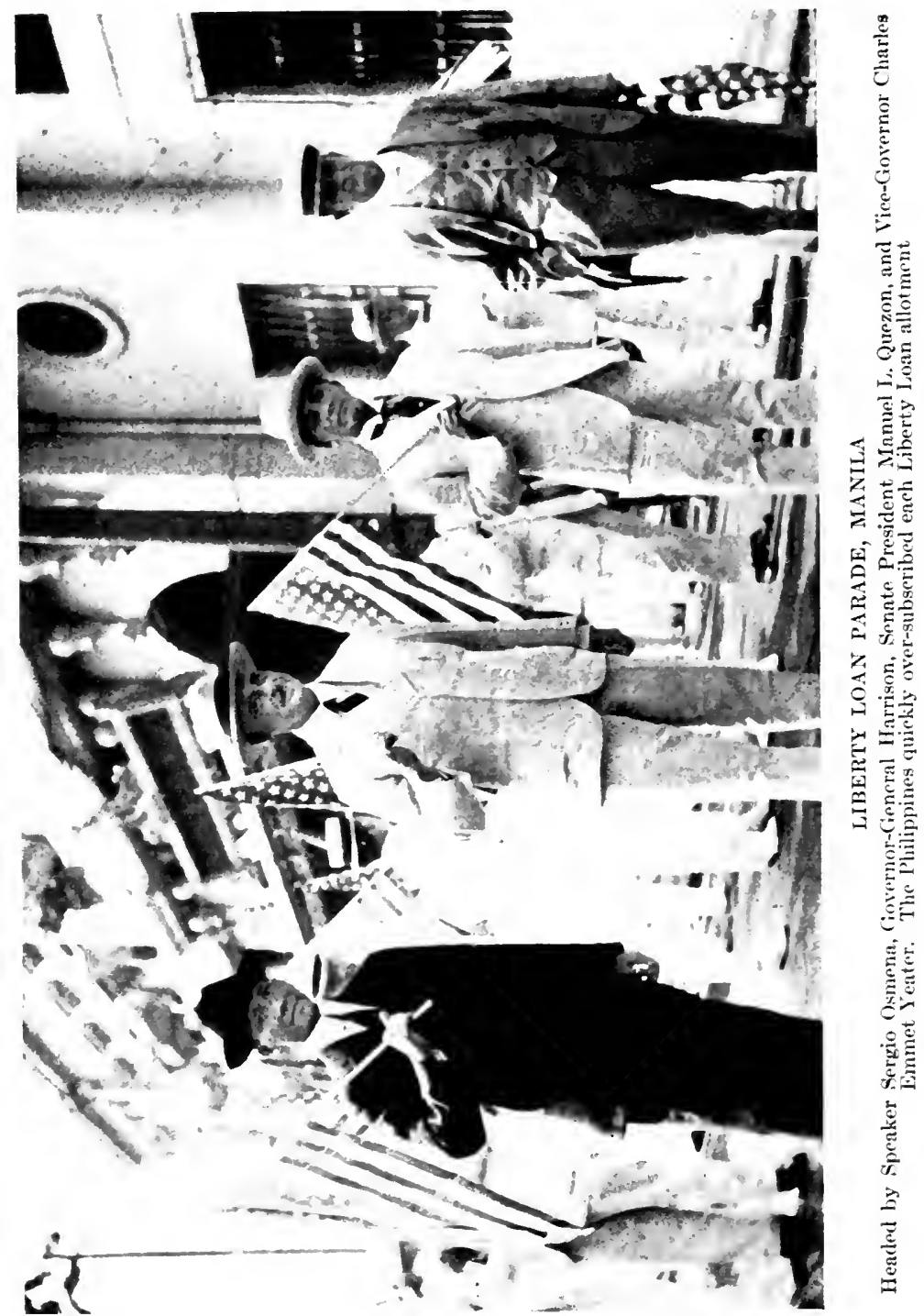


us any. The Philippines have improved both their financial system and their finances. In 1913 Governor Harrison spoke of two and a half millions of deficit yearly. At the end of 1918 there was a surplus of nearly $35,000,000$ pesos in the insular treasury. Our national debt is only $\$ 26,000,000$ (in 1919), for the redemption of which ample sinking funds have already been provided. This is a mere pittance compared to the staggering obligations incurred by the allied nations during the great war. 


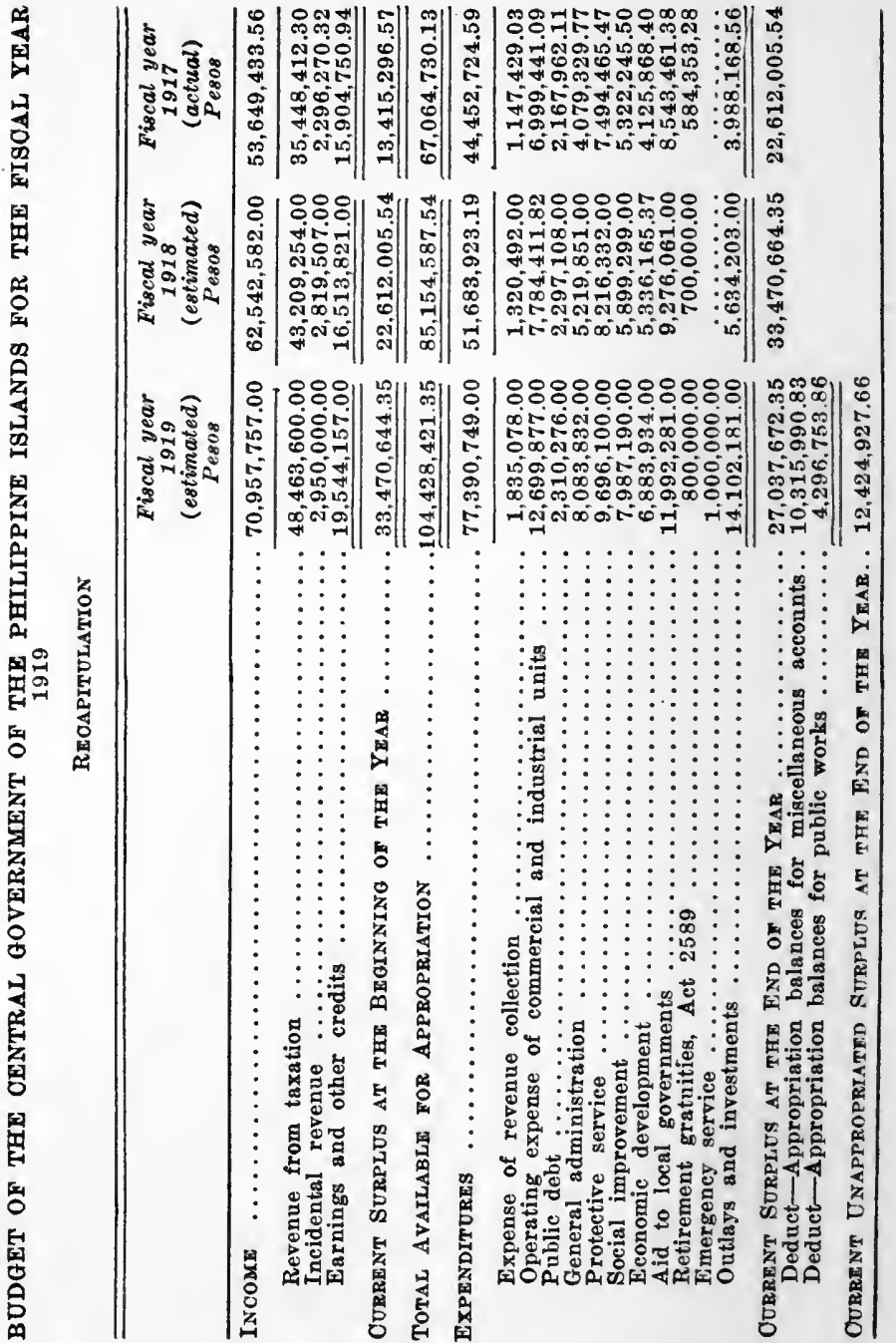




\section{CHAPTER IV}

FILIPINO LOYALTY DURING THE WAR

No greater proof can be found of the success of America's policy in the Philippines than the loyalty and friendship the Filipino people have shown her during the great war. Had there been no recognition of their right to independence, another story would probably be told. While the neighboring countries had to contend with a great deal of pro-German element, and in some cases ministries had to fall because of alleged anti-allied sentiment, the Filipinos from the beginning were heart and soul with the cause of the Allies.

The Philippines were not left out in the worldwide plan of German propaganda ; in fact, beliering that the Philippines were the weakest spot of the United States, the German Government laid special stress on the propagation of psychological material intended to weaken America's prestige in the Islands and make the Filipinos distrust Americans, and ultimately to bring 
the natives to their side. German spies were found in the Islands in plenty, and there was undoubtedly no question but that the German people would have given anything to start a rev. olution in the Islands against the sovereignty of the United States. But all German designs failed. The Filipino people remained faithful and loyal.

Other countries may have had a chance of furnishing more direct aid to America and the Allies, but the sincerity and enthusiasm with which the Filipino people espoused the cause of democracy has not been equalled in the Orient.' The seeds of democracy planted by America have borne fruit. The first resolution adopted by the Philippine legislature when it convened in 1917 was one of complete adherence to the cause of America. Four million pesos were immediately voted for the construction of a destroyer and a submarine to be offered to the service of America. The destroyer was launched on September 23,1918 , under the suggestive name of José Rizal, our greatest national hero.' The Filipino people over-subscribed all the Liberty Bond allotments given them. In the Fourth Liberty Loan, 12,000,000 pesos was the quota allotted us, and we subscribed 25,000,000 pesos. The Red 
Cross drive netted a million pesos. All the men and resources of the Islands were offered to the service of the United States.

The first Filipino known to fall in the fields of France under the American flag-Private Tomas Claudio - was acclaimed a national hero, and the National Guard Training Camp for Filipino volunteers was fittingly named Camp Claudio, after him. Six thousand Filipinos voluntarily enlisted in the American Navy, and are still serving as Uncle Sam's sailors. Four thousand Filipino laborers in Hawaii, who could have claimed exemption from the draft under the citizenship clause of the draft law, insisted on being enrolled under the Stars and Stripes. The loyalty was sincere and spontaneous on the part of the people.

- Presaging the inevitable opening of hostilities, the Philippine legislature passed an act providing for the organization of a Philippine Militia. It must be remembered that since the dispersion of the Philippine Revolutionary forces, we have had no army and, excepting the 5,000 constabulary soldiers organized half-civilly and half militarily and the other 5,000 Scouts in the American Federal service, the people have had no military training whatever. More than 
that, up to 1915 the American Government in the Islands had discouraged every military or quasi-military society or organization. The Boy Scouts had been disbanded for that reason, and all secret societies were carefully watched to see if they had any military object in view. The Filipinos are not allowed to bear arms except under a special license granted by the government. These facts will show how little military preparation the Filipinos had prior to the organization of the militia.

Immediately upon the declaration of war the Philippines offered to America the services of twenty-five thousand soldiers of the Philippine Militia, to be called the National Guard. Senate President Quezon, in a special trip to the United States, urged in person the acceptance of the offer as a sign of Philippine loyalty. In expectation of the acceptance of the offer, a quota of the 25,000 men was assigned to each province, and, without resorting to draft, 28,000 men soon were enrolled ready to go into training. Hundreds of our choice young menthe flower of our youth - left their high governmental and professional positions to join America's colors.

Our division could probably have had a chance 
of reaching France, of joining Pershing's Army, of helping sanctify St. Mihiel and Chatteau Thierry had it not been for inexcusable delay in its organization. A persistent group of men in whose hands lay the facilities for its organization saw fit to frustrate the offer of the Filipino people and prevent our division from leaving the Islands. ${ }^{1}$

The offer was made in April, 1917. The law authorizing the President to call our National Guard into federal service was passed on January 3,1918 . It took eight months to get the necessary legislation to enable the President to accept our offer. However, this was unavoidable. What is unpardonable was the fact that it took six months more to organize an Officers' School. The Department Commander, Gen. R. K. Evans, and a portion of his staff are to blame, says General Jones. The Philippine Department had naturally to be depended upon for facilities for organization, for instructors and even officers, and the War Department had urged its cooperation. Instead of providing all the necessary instructors, the military commander re-

1 I am indebted for the following facts regarding the history of our National Guard to the Adjutant General, General Ralph W. Jones. 
leased only six officers of the army to assist in the organization of the Officers' School, and student officers themselves had to be appointed on the teaching and administrative staff. The long delay in the organization of the Officers' School caused many Americans, including a large number of Constabulary officers who had applied for commissions, to go to the States to enter training camps there. General Erans' predecessor, General Bailey, had enthusiastically supported the idea of the offer, and approved the plan of securing a large percentage of the officers from his department, especially the Scouts. A law was passed in Congress on April 1, 1918, to make Scouts officers and enlisted men who might rolunteer, available for service in the National Guard. "Instead of making officers available," said Governor Harrison in his letter of June 20, 1918, to General Evans, " you relieved from duty with us one American officer and four Filipino Scout officers who were on duty with us." General Evans even refused to furnish tents to the National Guard, claiming that none was available, when it was found out afterwards that there was plenty of tentage at the department. In fact, with the exception of some 225 tents, all 
the others in use in the camp came from the department. There were some 25,000 surplus Springfield rifles in the military department, on which the National Guard counted for armament. Instead of placing them at the disposal of the Guard, General Evans suggested their return to the United States, and on this suggestion the orders for their transfer were issued.

At last the Governor-General was obliged to complain to the Secretary of War for this failure of the Department Commander to cooperate in the organization of the Guard. The complaint was cabled on June 9, 1918, and orders were immediately issued for the relief of General Evans by General Greene, although the latter did not arrive in Manila until August 6. " With no additional instructions to those received by General Evans," says General Jones, "the new Department Commander was able to do everything that was necessary to expedite the organization of the Division. We were furnished additional instructors. Our school was transferred to Fort McKinley. The preparation of the mobilization camp was pushed.

"Surplus supplies that were in the Department but not previously available (?) were as- 
sembled for use of the Division. Pressure was brought to bear to expedite the promised shipments from the United States.

"So rapidly did we progress that on November 11th, we completed mobilization of the Division at Camp Claudio. This was just four months and six days after the opening of our Officers' School."

But it was already too late. On the same date, November eleventh, the armistice was virtually signed. It was with regret that the Filipino people heard of the signing of the armistice, with their Philippine National Guard still on Philippine soil. Had the Philippines been independent from the beginning of the war, they could have given immediate military aid to the United States in the holy crusade against Prussian autocracy. The people were back of the United States, their loyalty was sincere, and their desire to help the cause of democracy was greater than that of any Oriental people. If they had not been obliged to depend upon the American Government, or its military department in the Philippines, for supplies, guns, tents and officers, and had they had a free hand in the organization and equipment of their National Guard, they would have been able to muster all 
their men and send them out to France in time to participate in the great battles fought by the American Army, and the Peace Conference would have seen representatives of the only Christian people in the Orient participating in the political and economic reconstruction of the world.

The different governmental departments also did their bit for the prosecution of the war. The Bureau of Education carried on a nationwide educational campaign. It subsidized a Philippine News Review which did much in the propagation of the causes and principles underlying the war. It was placed in the hands of high school and intermediate pupils, and was discussed in the class-room under the guidance of the teacher in charge. Through the pupils, thousands and thousands of parents, who have no newspaper available to keep them conversant with current facts, were reached. Forty thousand copies of a war catechism were distributed in the intermediate and secondary schools. Red Cross lantern views were made available to illustrate the war activities.

With the cooperation of the Bureau of Agriculture, the Bureau of Education carried on a campaign to increase food production. Dur- 
ing 1918, the schools increased the number of gardens from 50,000 to more than $\mathbf{1 0 0 , 0 0 0}$. There are now more than 100,000 pupils engaged in food production, under the supervision of their teachers. Under the auspices of the $\mathrm{Bu}$ reau of Agriculture, provincial and municipal food committees were established to further food production. The Woman's Club of Manila also helped in the campaign for food production with the establishment of branches all over the Philippines. These civic clubs control house lots for gardening. There are at present 132,721 of these lots. A home garden contest has been organized for each province, which is proving a great incentive to the people to take an interest in home gardening.

The Red Cross Chapter of the Philippines has done its share in war work. Filipino branches and auxiliaries have been organized to cooperate with the American unit. The Junior Red Cross has about 80,000 members in the public and private schools of the Philippines. Among the hospital supplies and garments for refugee children which were made in the school were included 13,000 abdominal bandages, 3,500 triangular bandages, and 33,000 refugee garments for French and Belgian children. 


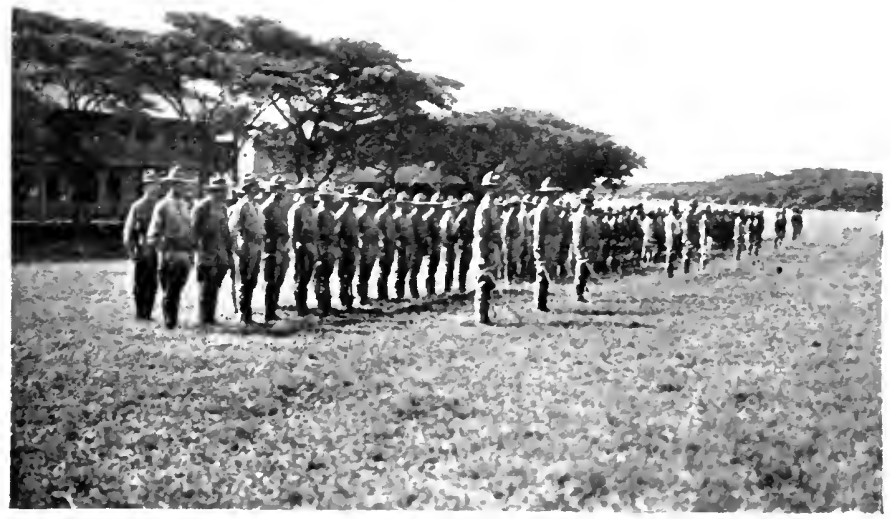

Photograph by Philippine Bureau of Science, Manila

BATTALION CEREMONIES, PHILIPPINE NATIONAL GUARD

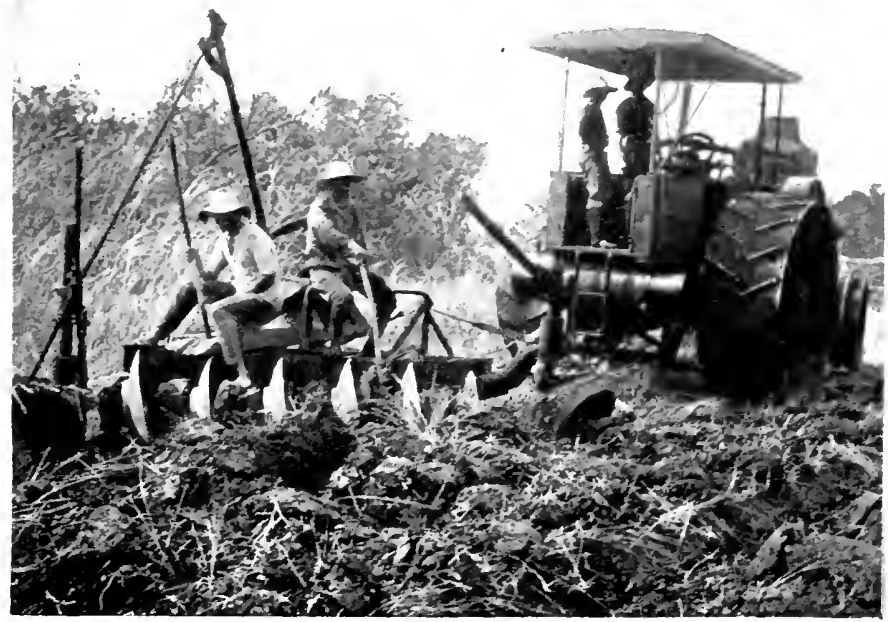

MODERN METHOD OF PLOWING LAND FOR SUGAR CANE PRODUCTION IN THE PHILIPPINES 


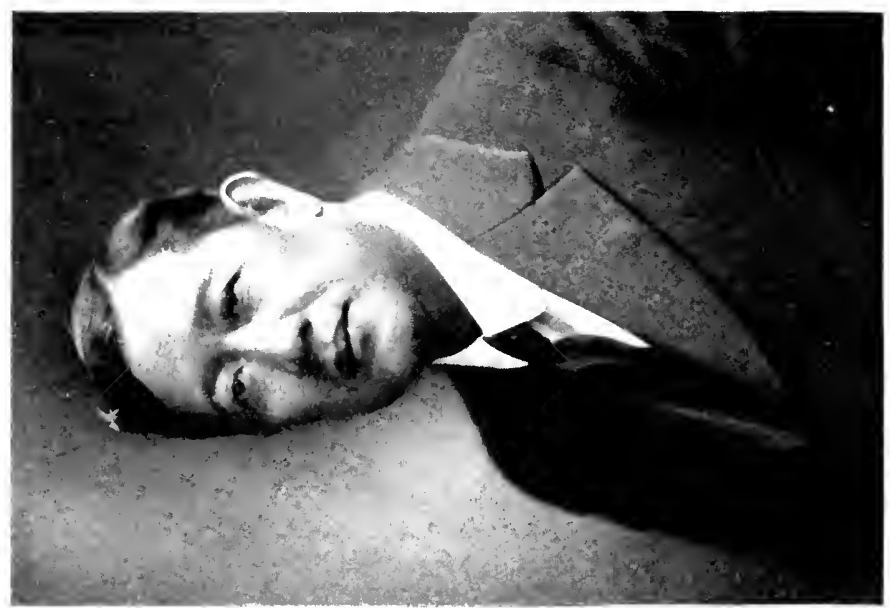

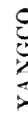

卌

总莣

蓄

间击

$\forall 0$

要

E

9

芯

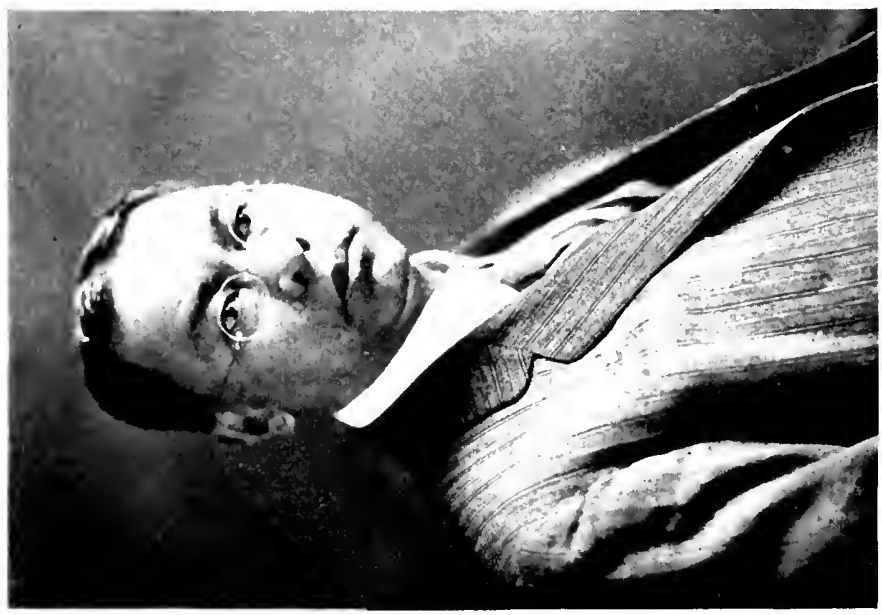

$\frac{3}{4}$ 
In addition to this, over 7,000.00 pesos' worth of woolen undershirts were bought with Junior Red Cross funds and rushed to Siberia for refugee work. The Philippine Bureau of Science has cooperated with the Chemical Warfare Service of the United States Army in an effort to produce in the Archipelago the greater possible amount of cocoanut-shell gas-mask charcoal.

The severe pinch of war was naturally felt in the Philippines. The prices of articles of prime necessity rose almost beyond the reach of our common people. But they bore the abnormal conditions with patience and resignation, merely petitioning the Government to intervene in the regulation of prices in order to protect the masses from starvation. Typical of their conduct was the manifestation made by more than 20,000 laborers, men and women, who paraded through the streets of Manila and then gathered before the Ayuntamiento to hand a petition to the Government requesting the necessary action to reduce the prices of foodstuffs and other necessities of life. Such a manifestation carried on in the most peaceful and orderly manner had probably no parallel in any other warafflicted country.

Owing to economic difficulties consequent upon 
the world war, some people would naturally suppose that brigandage and criminality would be a common occurrence. But no. Our people gave the least concern and embarrassment to the authorities. During the four years of war, complete peace reigned in the Philippines. America, uniting all her efforts to the prosecution of the war against the common enemy, took away the few thousand American white soldiers she had in the Islands. We answered that action by offering 25,000 men ourselves.

One would expect that our campaign for in. dependence would have been renewed with greater energy, that the war was the opportunity for an agitation requesting the United States to fulfill her pledge to the Filipino people. But the Filipino people restrained all agitation for independence. All their work was one of patient cooperation, apparently forgetting for the time being their own cause. During the two years that the United States was in the war, there was not an attempt made to remind America of the Philippine problem. "With fine self-restraint," said Secretary of War Baker, "the Filipino people refrained from active discussion of this question, deeming it inopportune at the time, and threw all of their energies and all of their 
resources into the common scale with the people of the United States." The reason is not far to seek. The Filipino people were convinced of the sincerity of the American people. Besides, America's cause in the war was really the Philippines' own cause writ large on the world's map.

"What we demand," said President Wilson, " is that the world be made safe . . . for every peace loving nation which, like our own, wishes to live its own life, determine its own institutions, be assured of justice and fair dealing by the other peoples of the world as against force and selfish aggression." 1 Again: "We are glad ... to fight . . . for the rights of nations, great and small, and the privilege of men everywhere to choose their way of life and obedience . . for democracy, for the right of those who submit to authority to have a voice in their own governments, for the rights and liberties of small nations." 2 "Every people should be left free to determine its own polity, its own way of development, unhindered, unthreatened, unafraid, the little along with the great and powerful." 3

1 President Wilson, January 8, 1918.

2 Ibid., April 3, 1917.

s Ibid., January 22, 1915. 
"Peace should rest upon the rights of people, not the rights of the government - the rights of people great and small, weak and powerful,their equal rights to freedom and security and self-government and to participation upon fair terms in the economic opportunities of the world." 1 These are the very same principles which have guided the political aspirations of the Filipino people since Admiral Dewey's arrival in Manila Bay. Self-determination and the consent of the governed were the very same principles we invoked when we demanded to be heard at the Paris Treaty Conference in 1898; they were the very same principles which made the Filipinos wage a disastrous and unequal war rather than unconditionally submit to American sovereignty; they were the very same principles we invoked when, defeated in war, we had to appeal to the spirit of justice and fair-dealing of the American people; and they were the very same principles which triumphed in the passage of the Jones Law, formally declaring the purpose of the people of the United States to recognize the independence of the Philippines as soon as a stable government can be established therein.

1 President Wilson, August 27, 1917. 
Upon the termination of hostilities in Europe, the Philippine Legislature unanimously adopted a resolution expressing "the gratitude of the Filipino people to the United States for the part they were allowed to take in the most far reaching enterprise ever undertaken by Democracy." "The Filipino people," the resolutions read, "who unqualifiedly sided with the United States when the war was thrust upon her, hereby renew their adherence to the noble purposes sought in this war and they place themselves again, as heretofore, at the pleasure of the American people, ready to contribute their modest, but cordial and determined service in the forthcoming task of reconstruction and peace. The Filipino people believe that Providence in choosing the American people as the leaders in this stupendous and immortal enterprise, has ordained in His high designs, that through the complete development and application to all peoples of the principles which have given birth to the United States, the fruit of victory, gained at the cost of untold sacrifice, shall not have come to naught. That the world be made safe for Democracy; that the rights and liberties of the small nations be forever secured and guaranteed; that the people, desiring to be free, be liberated and allowed to es- 
tablish, without fear or hindrance, a government of their own choosing and to change it at will, when so demanded by their best interest; that the weak be not at the mercy of the strong and that the spirit of selfishness and domination be destroyed and that there be established in its place, amongst all free men of the world, a new kingdom of constructive and equalitarian justice, based upon foundations that will make it universally secure and permanent. And when all these things shall have been accomplished, the universal belief shall have been confirmed, that the war which has happily ended has been fought in the interest of free humanity and the everlasting peace of the world."

President Wilson officially recognized the identity of Philippine ideals with those of America, and, through the Governor-General, answered the foregoing resolutions as follows:

"I have read with profound interest and gratification the admirable resolutions passed by the Legislature of the Philippine Islands in recognition of the termination of hostilities, and beg that you will convey to the Legislature not only my most cordial greetings but an expression of my profound gratitude that the association of the Philippine Islands with the United States should have issued in a perfect harmony 
of ideals and feeling and should have brought about that real friendship and mutual support which is the foundation of all sound political policy. I hope and believe that the future holds brighter fortunes for states which have hitherto been the prey of great powers and will realize for all the world the offers of justice and peace which have prompted the magnificent cooperations of the present war."

"WOODROW WILSON." 


\section{CHAPTER V}

\section{ECONOMIC DEVELOPMENT}

THERE have been a few people who be-

1 lieved that a policy of independence would stagnate business, and halt the economic development of the Islands. To them the mere mention of independence by the American Government would be enough to scare prospective capital away. Before taking his oath of office, President-elect Woodrow Wilson, in a speech in 1912, delivered at Staunton, Virginia, made what would now be considered a harmless statement to the effect that he hoped that the Philippines would be soon out of the frontiers of the United States. When news of that speech reached the Islands, said an American correspondent to the New York Herald, "like a clock in a house shaken by an earthquake, that new-found business expansion stopped; like a pulse in the body struck by lightning, the current of its life ceased to throb. Capitalists accustomed to place their money through brokers on commercial 


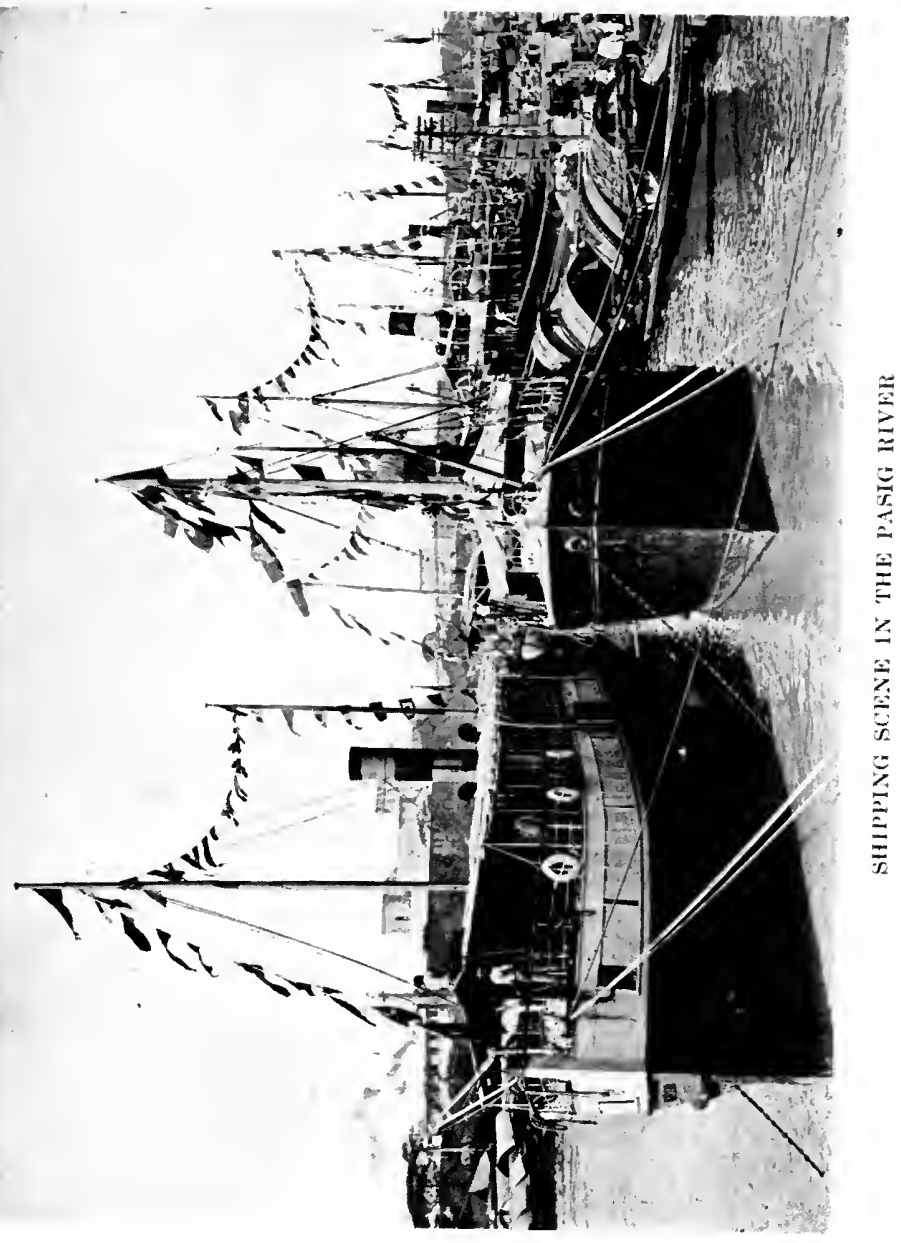




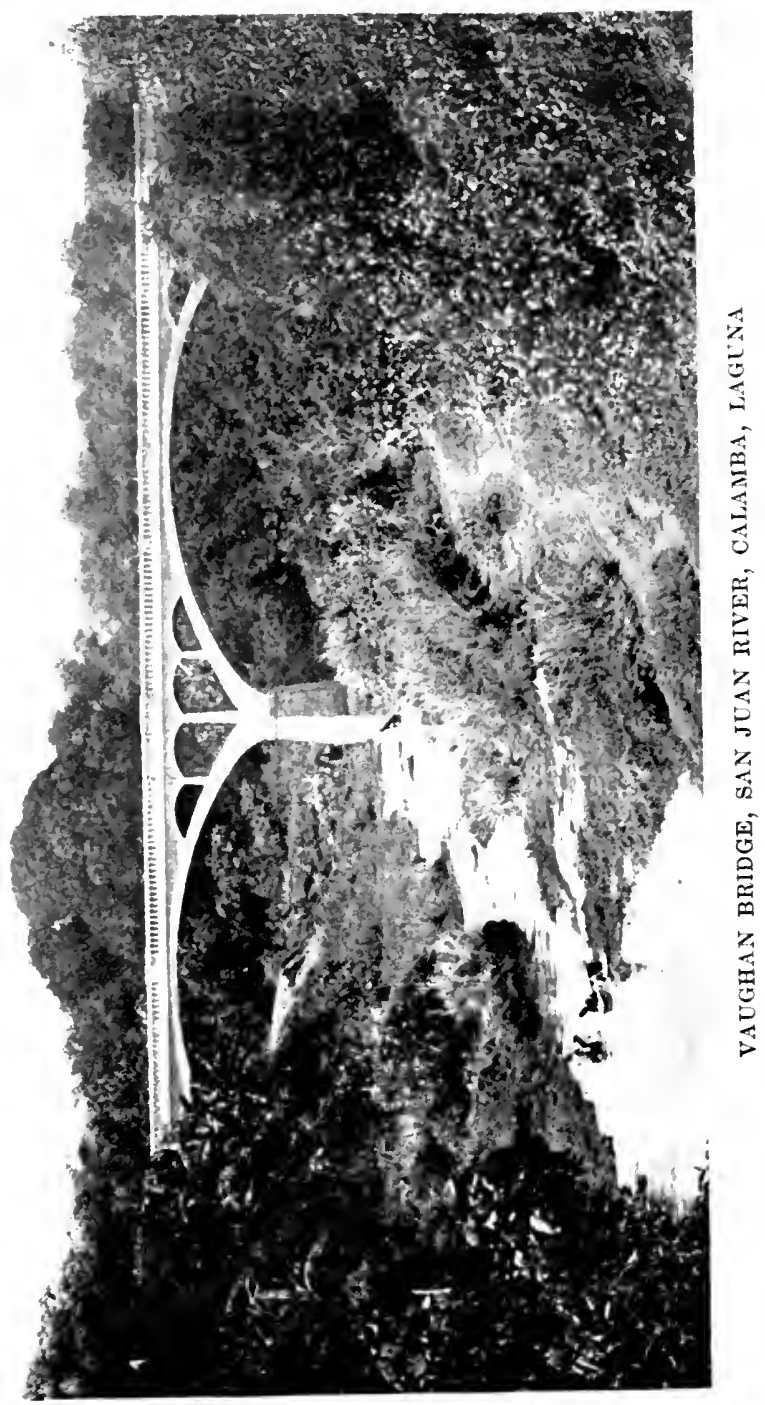


loans, drew in their funds; insurance companies and other institutions that had been investing their surpluses in local enterprises closed their doors to such transactions."

The idea contained in the President's speech was re-echoed by Governor-General Harrison upon his arrival in the Philippines, and was solemnly ratified by the American Congress when it passed the Jones Law, declaring it to be the purpose of the United States to give the Philippines their independence as soon as a stable government could be established therein. Six years have already elapsed since President Wilson's statement reached the Philippines and nearly three years since the passage of the Jones Law; but the announced business calamity has failed to materialize. On the contrary, the last five years have been for the Philippines the years of greatest prosperity and highest economic development. The total trade of the Philippines in 1918 was $468,563,496$ pesos, as against 202,171,484 pesos in 1913 . In $1918,63.4$ per cent of our trade went to the United States, as compared with 42.65 per cent in 1913, a fatal proof of the distrust of American capitalists and business men in a prospective independent Philippines! 
If the years of Philippine autonomy and preparation for independence has meant, economically, anything, it is a much closer commercial relation with the United States. Whoerer invented the theory that commerce is impersonal and independent of political and cordial relations will find food for thought in FilipinoAmerican economic relations, for in the latter case mutual political confidence and understanding has meant greater economic intercourse, and distrust and misunderstandings have made for meager economic relations.

The principal countries which are benefited bs the foreign trade of the Philippines are listed on the next page, showing the order in bulk of the share of each in the years 1913 and 1918.

Eren in the carrying trade a closer economic relation with the United States has been brought about. Of the total trade of the United States in 1914, British ressels carried 125,674,628 pesos; ressels of American registry second with $20,434,000$ pesos' worth of goods; German, a close third with $14,991,674$ pesos' worth; Japanese fourth with $14,609,810$ pesos; and the remainder was carried by Spanish, Norwegian and other nationalities.

In 1917, the British carrying trade dropped 


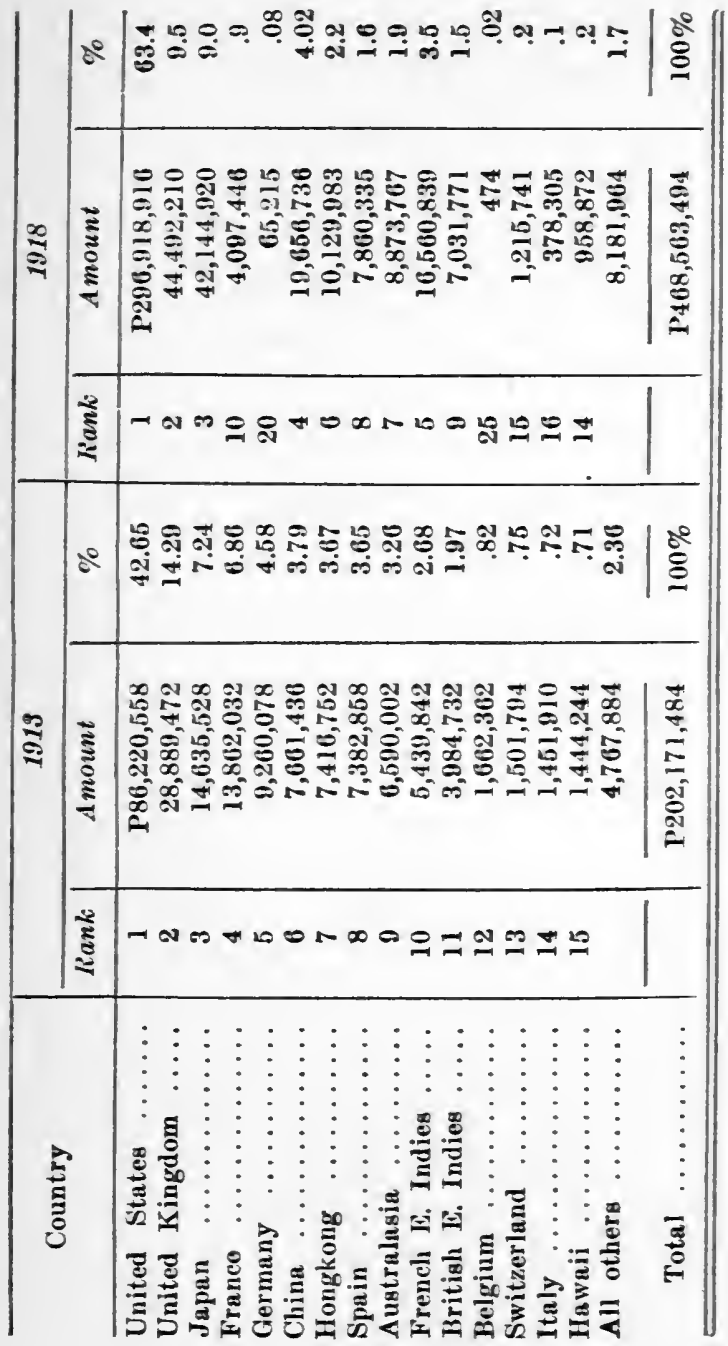


to $109,537,765$ pesos out of $322,802,674$ pesos, although they easily stood first. The nearest competitor in this carrying trade were the Japanese, with 87,285,927 pesos. Vessels of American registry stood third with $74,800,161$ pesos, and the remainder was divided among Norwegian, Spanish, Philippine and others.

In the year 1918, however, a marked change was noticed, for American vessels occupied the first place with a total of $162,861,635$, followed by the British with 121,975,745, then the Japanese a close third with $107,698,918$, the Norwegian fourth with $17,589,898$, the Philippine with $15,568,718$, the Danish with $13,078,701$, the Chinese, the Dutch, the Spanish and a few others the rest.

Another "platitude" that was given currency in the Philippines was that the economic independence must precede political independence and that therefore the people should quit demanding political rights and work for economic independence first. Our experience of the last five years has meant just the opposite: that no people can advance economically unless the political instrumentalities are given them first; that the greatest instrument of economic progress is political autonomy. 


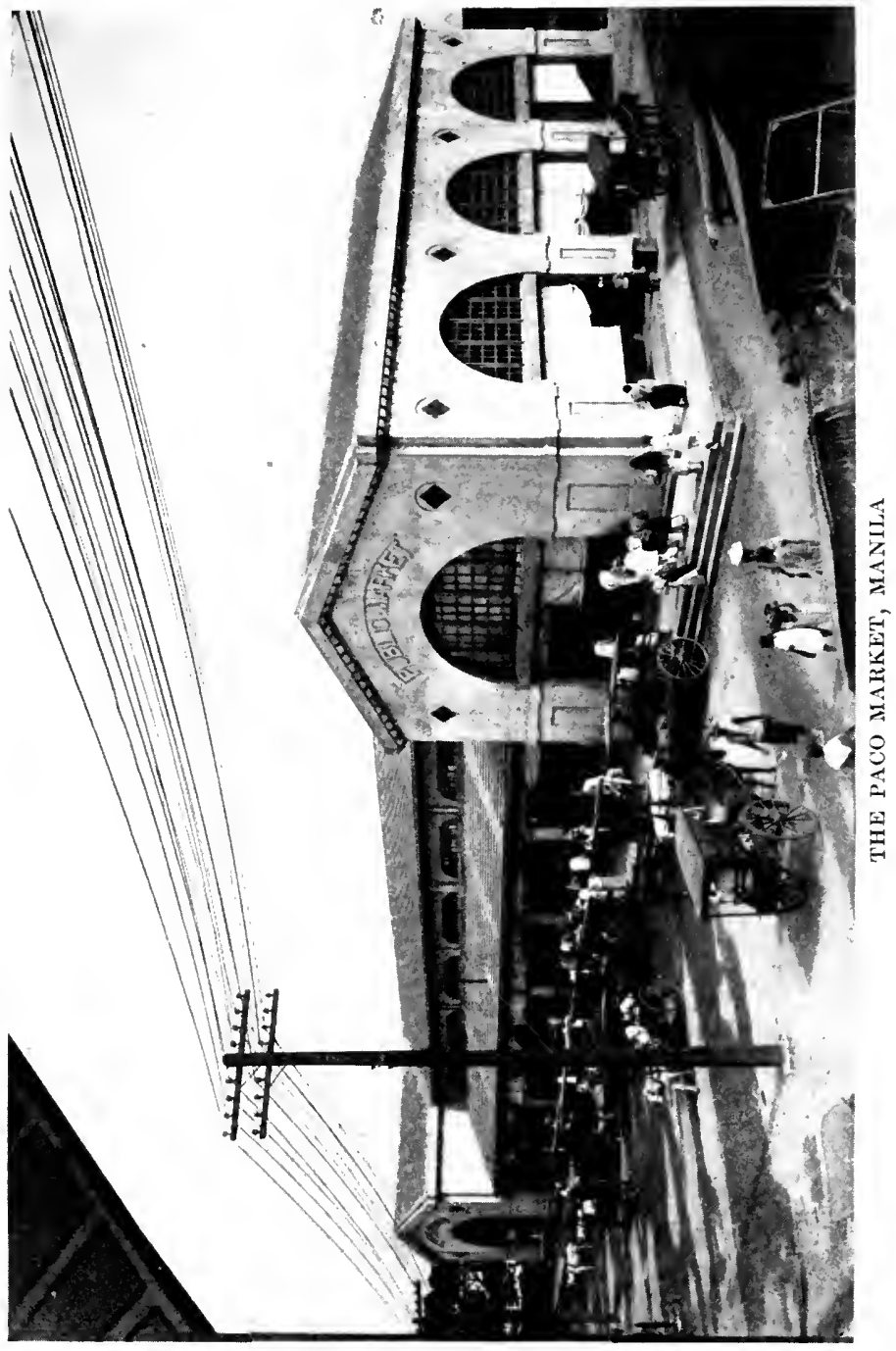




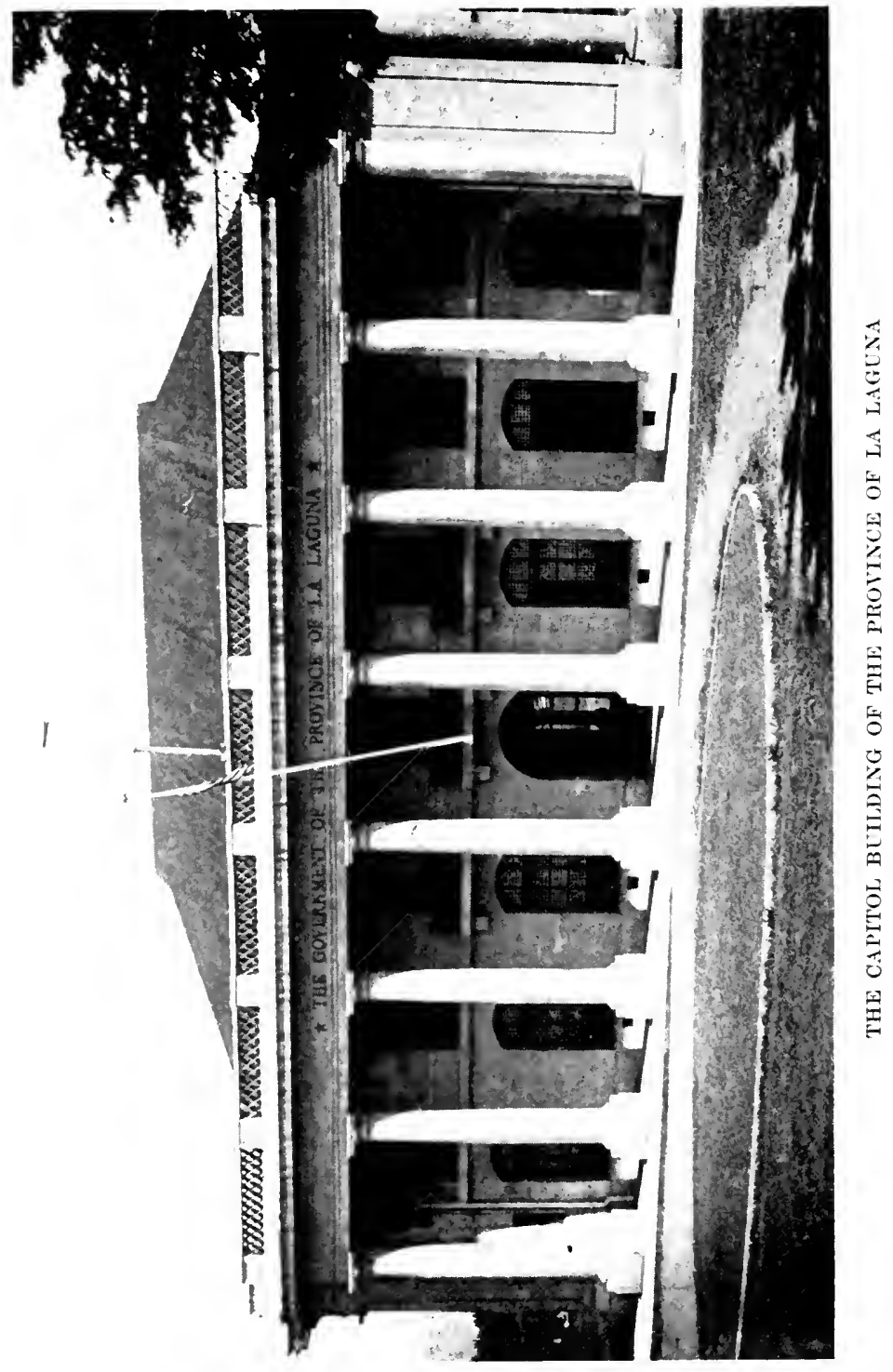


Before the extension of Philippine autonomy, with credit and banking facilities in the hands of foreigners, the Filipino business men and manufacturers could not compete with their rivals for lack of credit. Commerce was in reality in the hands of foreigners. But the establishment of political autonomy saw a phenomenal growth in the business activities of the people. A Philippine National Bank was established by the Government, which would not shut its doors to Filipino enterprise, and from barely 20,000,000 in 1916, the bank's resources increased to more than $230,000,000$ pesos in 1918 . This is probably unprecedented in the history of banking.

The total foreign commerce in 1913 was $\$ 107$, 685,742 with a balance against her of $\$ 5,500,000$, while last year, 1918, her foreign commerce reached $\$ 234,281,747$ with a balance of trade in her favor of $\$ 37,083,324$, or an increase of $\$ 133$,196,005 of the 1918 trade over that of 1913 , an increase of 131 per centum from 1913 to 1918.

With respect to our monetary circulation, we had in 1913 , or a year before the war, $\$ 25,348,626$ or $\$ 2.76$ per capita, while at present we have in circulation $\$ 66,301,484$, or $\$ 6.74$ per capita.

Taxation in the Philippines was $\$ 2.14$ per 
capita in 1913 as compared with $\$ 2.68$ per capita in 1917.

A true sign of the notable development which up to this time has been shown in the commerce of our country are the 3,065 domestic corporations and partnerships organized in the Islands during the last few years with a capital aggregating $\mathrm{P} 452,192,197.43$, not to mention 95 large American and a considerable number of world-famed foreign concerns with enormous additional capital, also having agencies and branches in the Islands.

The Filipino people, freed from misgivings as to the political future of their country, have begun in earnest to attend to the economic development of the Islands. A bureau of commerce and industry has been created by the Philippine Legislature, to foster commerce. A large amount was also appropriated to finance scholarships abroad, and many deserving young men have thus been enabled to acquire extensive business education abroad. Only a few rears ago promising young men were urged to study only law or medicine. Today agricultural, industrial and commercial pursuits are no longer despised. The Filipinos are fast learning business organization and management from the 
Americans. Ten years ago the commercial aspirations of the few who had the audacity to seek financial backing from their countrymen for some enterprise were cooled by the distrust and pessimism of the people. Today the whole country has caught the fever of commercial expansion, and business undertakings are springing up everywhere with Filipino capital and management.

The unprecedented success of the Philippine National Bank during its two years of existence is an eloquent testimony of the business capacity of the Filipinos. For the first time in the history of the Islands, native Filipinos have been put at the head of a banking institution. Almost all of the officials of the Philippine National Bank are Filipinos, and with the opportunities afforded by the Bank to the young men in its employ to master the intricacies of banking, the institution will further benefit the community by the trained men it will turn out to help organize and manage future banking institutions, which are indispensable to commercial prosperity.

The Hogar Filipino is a mutual savings association, and constitutes the maiden effort of the Filipinos in this line of business. The suc- 
cess of the association is beyond doubt and its financial soundness beyond question.

Notable among the engineering concerns of the Islands are the Earnshaws Slipways and Engineering Company, capitalized at 6,000,000 pesos; the Philippine Engineering Company, capitalized at 250,000 pesos, and El Varadero de Manila.

The Insurance field has not been left untouched by the Filipinos either. The Insular Life Assurance Company is the earliest among such ventures, and the success it has achieved has stimulated interest in the insurance business. The Filipinas, Compania de Seguros, capital $1,000,000$ pesos, accepts property and marine risks as well as life. The National Insurance Company, capital 5,000,000 pesos, is of recent origin and so far has limited itself to marine insurance. In the realm of fidelity and employers' liability insurance stands foremost the Philippine Guaranty Company, capital 250,000 pesos.

Shipping, especially interisland, has also received the attention it deserves of the Filipinos. Madrigal and Company is the biggest shipping concern in the Philippines today. This company operates about twelve ships, which, out- 
going, transport sugar, hemp and other Island products to Japan and China, and, incoming, supply the country with coal and rice. The Compania Maritima has a fleet of interisland steamers which connect Manila with the southern ports. The Yangco Steamship Company, capitalized at $4,000,000$ pesos, operates a line of steamboats between Manila and the nearby towns and adjacent ports. Fernandez Hermanos is another shipping concern which is fast acquiring additional ships. La Compania Naviera, organized only in 1918, is also acquiring steamers for the interisland trade.

In the cocoanut oil business the Filipinos were not caught sleeping. The millions they invested in the oil business proves that enterprise is not dead in them. Many big oil factories in Manila at present are purely Filipino in capital and management.

The Compania Mercantil de Filipinas is a close competitor of the foreign import and export houses in the Philippines today. In two years its business has expanded considerably and bids fair to outstrip similar foreign concerns within a few years. This firm is a credit to its managers and founders. There are scores of Filipino export and import firms similar to this, 
though of smaller proportions, and indications are that their business is booming.

Other commercial and industrial ventures worthy of note as pioneers in their line are the Philippine Tannery Company, and the Philippine Net and Braid Manufacturing Company. The San Miguel Brewery, incorporated at 4,000,000 pesos, have been engaged exclusively in beer manufacture, and Ayala Y Cia. are preeminent in the distillery and alcohol business.

The majority of the cigar and cigarette factories in Manila are owned and operated by the Filipinos. The first of these factories is La Germinal, which has acquired local and international fame as producer of high-class cigars and cigarettes.

The writer, at a Lake Mohonk conference, heard the argument that the minute the Filipinos were given political freedom, the public improvements so magnificently built by American officials would be neglected, and that grass would begin to grow on the splendid roads and streets of the Islands.

At the end of 1914, there were only 2,317.6 kilometers of first class road maintained by the caminero (cantonmier) system. The length was nearly doubled at the end of 1918, there 
being now 4,023.4 kilometers of first class road maintained (see Report of Bureau of Public Works for 1918). At the time of GovernorGeneral Forbes, whose main boast was his achievement in public works, the government rarely spent over $3,000,000$ pesos a year. The appropriation for 1919 for public works alone is $17,000,000$ pesos.

The artesian wells which are proving such wonderful health measures for the people of the Philippines have also increased in numbers. There are now 893 wells as against only 250 in 1913.

The Philippine Government has successfully followed a policy of nationalizing and controlling industries when the public welfare demanded such a step. It took over the Manila Railroad Company, enlarged its activities, and made it a much more efficient means of transportation. It is now (1918) operated with a million dollar profit every year. A law has recently passed to extend the lines so that it will only be a question of time when the island of Luzon will be crossed by railroads from one end to the other.

Several years ago the government established a Sugar Central Board to further the develop- 
ment of sugar centrals in the Islands. It should be remembered that the principal source of wealth of Cuba and Hawaii is the sugar-cane. The last few years have seen a tremendous growth of this industry, and it will only be a question of years when the Philippines will surpass Hawaii in the production of sugar. Since 1913 in the island of Negros alone, over thirty million pesos have been invested in sugar mills, or centrals, as they are called in the Philippines.

In the development of resources which are un. touched by private enterprise, the Philippine Government has taken the lead. In order to supply the need for coal, the price of which increased tremendously during the war, the National Coal Company has been established with the government as the chief stockholder. In order to aid more effectively the general economic development of the country; to suppress profiteering, and to aid and foster all legitimate business enterprises, a National Development Company has been organized, capitalized at fifty million pesos.

In the solution of labor troubles the Government has also taken a very deep interest. The completely Filipinized legislature passed a law creating a Bureau of Labor to serve as mediator 
between labor and capital. It must be of interest to the laborers here to know that both the Director and the Assistant Director of the Bureau are labor leaders. We have no compulsory arbitration of labor disputes in the Philippines, but voluntary mediation has been successfully applied. The Philippine Legislature has facilitated the acquisition by laborers of homesteads, and is undertaking a policy of financing settlers who want to migrate to the less densely populated islands like Mindanao. They supply capital and work-animals to laborers who desire to go into these thinly populated districts. The system is built on a basis similar to the Land Settlement Act of California. That there is harmony between labor and government in the Philippines is proven by the fact that, according to a cable message from Manila, one hundred and twenty-one labor leaders recently agreed not to declare any strikes while the Philippine Mission, sent by the Philippine Legislature, is in the United States working for independence.

The Government control of charities must also be mentioned. The Public Welfare Board has been organized to supervise and organize all governmental aids to charity and to apportion 
government funds to the needy charitable institutions. The government maintains special institutions for the defective. There is a school for the deaf and blind in Manila. There are orphanages and reformatories for young offenders, and a juvenile court will be soon established if the bill recently introduced should become law. The Philippine Health Service, now under a Filipino chief, has established free dispensaries in every part of the Philippines where poor people can receive free treatment. There is a Leper Colony established at Culion where lepers are treated and from which several of them have already left after it was successfully demonstrated that they were completely cured.

There is no reason why the Filipino people, under the present or any other government, will not be able to continue the economic development of the country, opening their doors to all foreign investment. There is probably no other country in the Orient which welcomes foreign capital more than the Philippines. This is more true in the case of American capital. In fact, the Filipinos do not consider American capital foreign. All sorts of facilities are given to Americans who desire to do business in the Philippines. There is nothing in the laws of 
the Islands that is antagonistic to American capital, and the attitude of the people towards it cannot be more pleasant and favorable. Scores of great American corporations are doing business in the Islands, while millions of American money find their way into the capitalization of companies incorporated under the laws of the Islands.

There is a place for everybody in the Philippines. The Filipinos realize that American brains, capital and initiative constitute a great factor in the development of their resources and in placing the Philippines on the high road to prosperity and wealth. 


\section{CHAPTER VI}

\section{PROGRESS OF LOCAL GOVERNMENT ${ }^{1}$}

The Philippines are politically sub-divided
into provinces, and these in turn into municipalities and townships. There are fortyfive provinces, divided into thirty-three regular provinces and twelve special provinces. ${ }^{2}$ The regular provinces are inhabited by Christian peoples and are financially self-supporting. The special provinces contain non-Christian people as well as Christians, but are not far enough developed to be on an equal footing with the regular provinces. There has been a ten-

1 This Chapter is taken mostly from a special memorandum to the Secretary of the Interior by the Chief of the Executive Bureau.

2 The regularly organized provinces are Albay, Ambos, Camarines, Antique, Bataan, Batangas, Bohol, Bulacan, Cagayan, Capiz, Cavite, Cebu, Ilocos Norte, Ilocos Sur, Iloilo, Isabela, Laguna, La Union, Leyte, Misamis, Nueva Ecija, Occidental Negros, Oriental Negros, Pampanga, Pangasinan, Rizal, Samar, Sorsogon, Surigao, Tarlac, Tayabas, Sambales, Abra, Romblon.

The special provinces are Batanes, Mindoro, Mountain Province, Neuva Vizcaya, Palawan, Agusan, Bukidnon, Cotabato, Davao, Lanao, Sulu and Zamboanga. 
dency on the part of large provinces to split up into two or more provinces, whenever the financial conditions warrant such a division and the people concerned desire it. Since 1913, two new regular provinces have been added; namely, Abra, formerly a sub-province of Ilocos Sur, and Romblon, formerly a sub-province of Capiz. The Legislature also recently authorized the Governor-General to separate Camarines Norte from Ambos Camarines and organize it as an independent province.

Similarly there has been a tendency to increase the number of municipalities. In 1913 there were $\mathbf{7 4 5}$ municipalities, whereas this year (1919) there are 792. This number does not include the several municipalities created in the provinces within the Department of Mindanao and Sulu. Municipalities are governed by a municipal president, vice-president, treasurer, secretary and councilors. All of these are elected except the secretary and treasurer. There are also municipal boards of health or municipal sanitary divisions. The cities of Manila and Baguio have special charters.

Although, as a general rule, the organization. of new provinces and municipalities is favored, yet it has been the policy not to authorize such 
organization unless the social and economic conditions of the places concerned fully warrant such action. The creation of so many provinces and municipalities, therefore, is indicative of the progress being made along social and economic lines in our provinces and municipalities.

Formerly, regular provinces and municipalities were governed by Acts Nos. 82 and 83 of the Philippine Commission, and numerous other acts amendatory thereto. All these acts were harmonized, consolidated and embodied in an Administrative Code, which, as recently revised, is known as the Administrative Code of 1917. Another step to make provincial and municipal legislation more systematic and uniform has recently been taken. Formerly, in addition to the provincial and municipal laws applicable to the regular provinces and municipalities, there were provincial and municipal laws applicable to the provinces and minor political subdivisions in the Department of Mindanao and Sulu and laws applicable to the other special provinces and political subdivision therein. These latter laws are obsolete and no longer warranted by the progress made in those special provinces since their enactment. For this reason, and for the sake of uniformity, these laws have been repealed 
recently and substituted, with slight modifications, by those in force in the Department of Mindanao and Sulu which have proved to be highly progressive, and have contributed largely to the rapid political, social and economic advancement in that region.

There are other important acts passed by the Philippine Legislature affecting provinces and municipalities. The trend of legislation as shown by these acts is quite significant. There is a decided policy of extending more and more popular control over local governments. To this end formerly appointive provincial offices have been converted into elective. The provincial board that forms the legislative body in the province was formerly constituted by the provincial governor (elective), the provincial treasurer (appointive) and the third member (elective). By Act No. 2501, passed on February 5, 1915, the provincial treasurer ceased to act as member of the provincial board and the Governor-General was authorized to appoint a new member to be chosen from among the municipal presidents whose term of office was made coincident with the term of the two elective members of the board. Inasmuch as municipal presidents are elected by popular rote, the effect 
of Act 2501 in requiring that the appointive member of the provincial board be chosen from among the municipal presidents of the province, was undoubtedly to extend popular control in the administration of provincial affairs in the regularly organized provinces. Act 2586 enacted in February, 1916, further extended popular control in the administration, by providing that the appointive members of the provincial board shall be elected by popular vote. In 1914, the office of Lieutenant-Governor in the subprovinces of Marinduque, Tayabas; Catanduanes, Albay; Masbate, Sorsogon; Siquijor, Occidental Negros; Abra, Ilocos Sur (subsequently made a province) was made elective.

Popular control was also extended in the special provinces. In 1915, the office of third member of the provincial boards of Mindoro, Palawan and Batanes was made elective. In 1916, the third member of the provincial board of Nueva Vizcaya was also made elective. So was the office of third member of the Mountain Province made elective in 1917. In 1916, the office of provincial governor of Mindoro was likewise made elective. The provinces in the Department of Mindanao and Sulu were not entirely left out. The office of third member in 


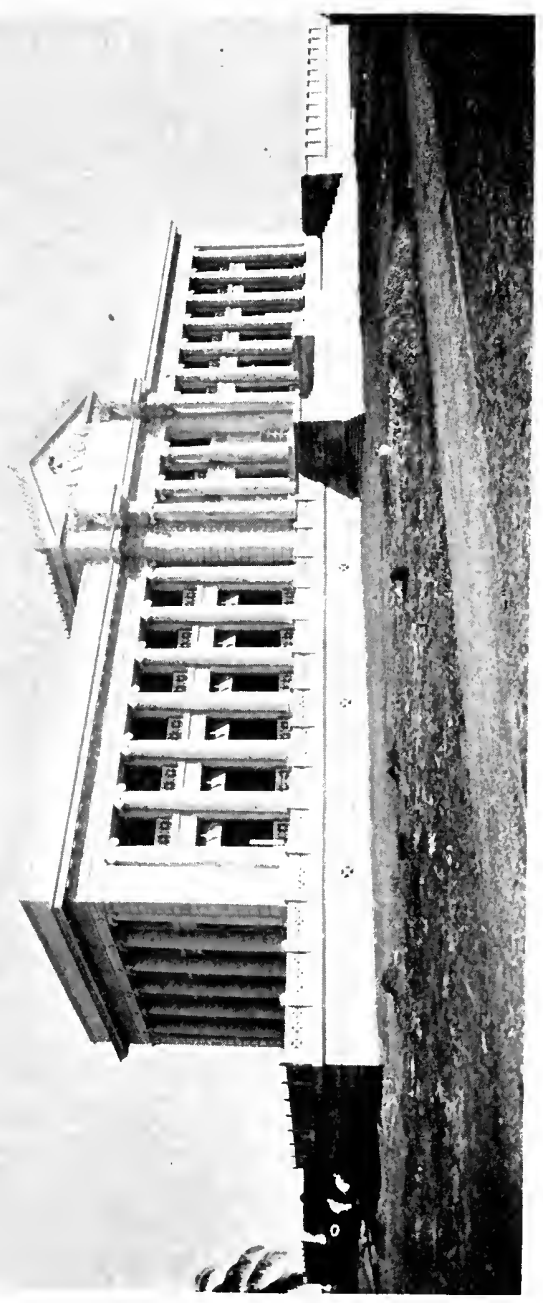

r. 


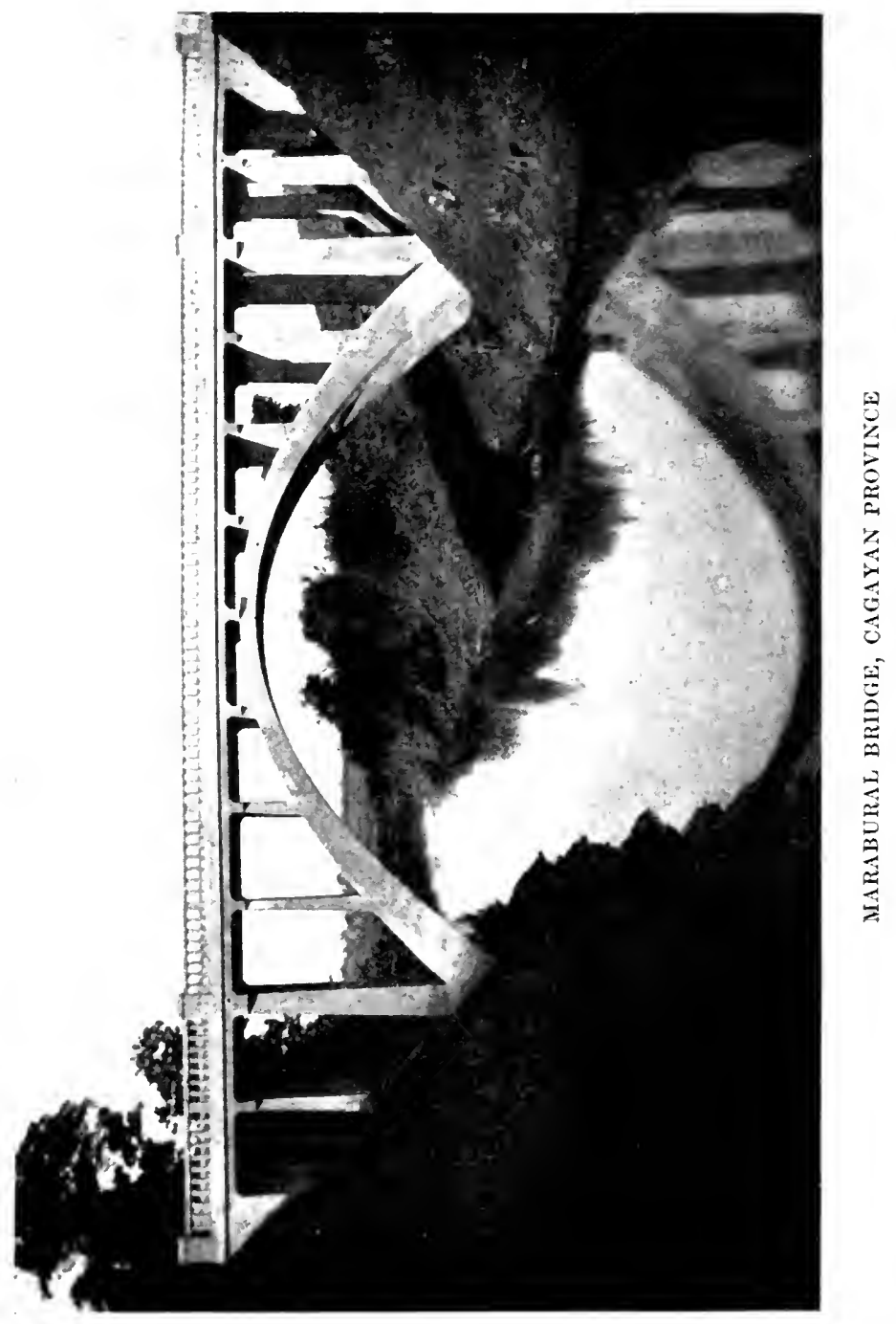


each of them was made elective also, although not by popular vote, but by the vote of the municipal vice-presidents and councilors. But as these officials are elected by popular vote, it will readily be seen that the change is quite a significant one.

All these changes form tangible evidence of the progress achieved towards the extension of popular control. As the important municipal offices are also elective, almost the entire work of the provincial and municipal governments, therefore, is being conducted by the Filipino officials elected by popular vote.

The six years of Philippine autonomy are also characterized by the enactment of laws providing for the promotion of friendly relations and union between the Christian and non-Christian inhabitants of the Philippine Islands and the extension to the Department of Mindanao and Sulu and other special provinces of laws of general application in the regularly organized provinces. (See Acts 2396, 2406, 2413, 2417, 2522, 2539, 2545, 2658, 2662 and 2664. Also see Chapter VII.)

In 1917 and 1918, all provincial governors who are the chief executives of the provinces were Filipinos except the governors of the provinces 
of Cotabato, Lanao and Sulu in the Department of Mindanao and Sulu. Of the 46 provincial treasurers who are the chief financial officers of the provinces, 39 are Filipinos and 7 are Americans. In other offices which may be termed quasi-provincial offices, the Filipinos have also gradually assumed control. Of the 39 district health officers, 38 are Filipinos and only one is American. In the municipalities, with the exception of 16 American ex-officio justices of the peace who, of course, have no administrative functions, all officials are Filipinos. As may be seen, the last five years of democratic administration have witnessed the gradual and steady assumption by the Filipinos of the entire provincial and municipal administration.

The supervision and control over provinces and municipalities were formerly exercised by the Governor-General, through the Executive Secretary. Now, this power is entrusted to the Secretary of the Interior, through the Chief of the Executive Bureau, both of which offices are filled by Filipinos. The provincial and municipal governments, to an increasing degree, are being encouraged to a more ample exercise of self-government and accustomed to less active supervision by the Central Government, the lat- 
ter intervening only when the law so requires, or whenever the officials abuse their powers or grossly neglect their duties to the detriment of the public interests. Unnecessary intervention in provincial and municipal affairs has been discontinued and the autonomy of the provinces and municipalities respected in so far as consistent with the safety of the government and the general welfare. The provinces and municipalities are not subjected to intervention by the Central Government as long as they confine themselves within the limits of their legal powers. Thus, the Executive Bureau no longer revises on its own initiative, acts, resolutions, etc., of the municipal governments, but takes cognizance of questions involving such acts and resolutions only when appeal thereto is taken pursuant to the provisions of section 2235 of the Administrative Code of 1917, in which case only the point of legality or illegality of the act or ordinance concerned is decided, or when protest is filed by a person or persons affected by or interested in such acts or resolutions, in which case this office passes upon the protest and if it finds the same to be well-founded makes the necessary and proper suggestions to the provincial board which invariably follows them and 
takes action accordingly. Nor does it pass upon charges against municipal officials except those which, upon investigation, are submitted to it by the provincial board under the provisions of sections 2188 et seq. of the Administrative Code of 1917.

The policy of extending local autonomy has been productive of beneficial results. Provincial and municipal officials have risen to the occasion. The number of administrative cases against municipal officials has gradually and considerably decreased. Thus, in 1914, there were 80 administrative cases against municipal presidents, 27 against vice-presidents and 165 against municipal councilors; in 1915, 50 against municipal presidents, 21 against vice-presidents and 86 against municipal councilors; in 1916, 39 against municipal presidents, 14 against vicepresidents and 27 against municipal councilors; and in 1917, 18 against municipal presidents, 2 against vice-presidents and 48 against municipal councilors. According to official records, there were not more than 70 administrative cases against municipal officials received in the Executive Bureau for instruction or final action during the year 1918. More noteworthy is the fact that from 1914 to date, no provincial official 
has been subjected to administrative proceedings. This shows a decisive improvement in our municipal administration, a better realization on the part of our municipal officials of the responsibilities contracted by them with their constitutents - the people whose sovereign will has exalted them to position and power.

Nor has progress been along political lines alone, but provinces and municipalities also have improved economically. The revenues of provinces and municipalities have constantly increased from year to year during the last five years. In the case of the province of Cebu, for example, it appears that in 1913, the revenues of all the municipalities therein totalled 554,321.49 pesos; in $1914,580,466.57$ pesos; in 1915 , $660,834.03$ pesos; in 1916, 710,882.73 pesos; and in $1917,831,606.37$ pesos. In 1913 , the revenues of all the municipalities, townships and settlements amounted to $7,152,541.90$ pesos. In 1917, this amount reached the sum of 11,401,983.94 pesos. In 1913, the total expenses of operation of all municipalities, townships and settlements aggregated $5,869,454.87$ pesos. In 1917 , the amount totalled 8,696,535.51 pesos.

The chief sources of revenue of the provinces are the cedula (poll) tax, the percentage of In- 
ternal Revenue taxes accruing to them and the real-property tax; of the municipalities, the cedula tax, Internal Revenue licenses and percentage, real-property tax, municipal licenses, fisheries, cattle registration and rents, profits and privileges. The financial condition of the provinces and municipalities is satisfactory. Their financial resources have permitted them to undertake necessary public works, such as the construction and repair of school-houses, municipal government buildings, roads, and bridges, etc. And, in cases where their financial resources have not been sufficient to permit them to carry out public improvements, the provinces and municipalities readily have contracted loans which they always have endeavored to pay at the earliest possible date. They have practiced strict economy to be able to meet such obligations. In countless instances, the people have shown commendable public spirit by voluntarily contributing money, material and labor for these purposes. The policy is to permit provinces and municipalities to increase local taxes, the proceeds whereof are to be devoted to such public works as may be undertaken by their govern: ments.

Not only have the provinces and municipali- 
ties improved politically and economically, but, as a result of their local freedom and prosperity, they have encouraged and effectively contributed to the establishment of public schools, the organization of a system of provincial and municipal sanitation, and the execution of public works; such as roads, bridges, provincial and municipal buildings, markets and slaughterhouses, artesian wells, wharres, docks and piers, parks and monuments.

It is, indeed, gratifying to note the constant increase of schools in the provinces and municipalities to meet the crying demands of the Filipinos for popular education. The Philippine public school system is one of the largest under the American flag, and it is growing. Between 1912 and 1918 the total number of children in school increased from 440,000 to 675,000 , a gain of fifty-four per cent in six years. The larger number of pupils attended 4,700 schools, the smaller 3,000, which means that in 1918, 1,700 more communities enjoyed educational privileges than in 1912. During the same period the number of intermediate pupils grew to 67 ,000 , a gain of one hundred sixty per cent; and the number of high school students reached 16,000 , a gain of two hundred twenty per cent. 
And the Philippines have had no compulsory attendance law.

The liberality with which the Philippine Legislature has appropriated money for the promotion of public education as evidenced by the Appropriation Acts, and the prompt response of provinces and municipalities in appropriating funds for the same purpose, have permitted this increase from year to year of schools in the provinces and municipalities. Let it be said that at the present day the cry for more sehools is resounding in every nook and corner of the Archipelago. This has been echoed in the halls of the Philippine Congress which promptly and unhesitatingly responded by appropriating the large sum of $30,000,000$ pesos to defray the expenses of a five-year school program calculated to accommodate in the schools all Filipino children who may desire to attend them. And, in addition, the voluntary contributions of the people to the support of education increased from P198,000 to P479,000 from 1912 to 1917. No clearer evidence is needed that the Filipino people are back of the public schools.

This impelling movement for popular education, this yearning of an entire people for intellectual advancement is evidence of already 


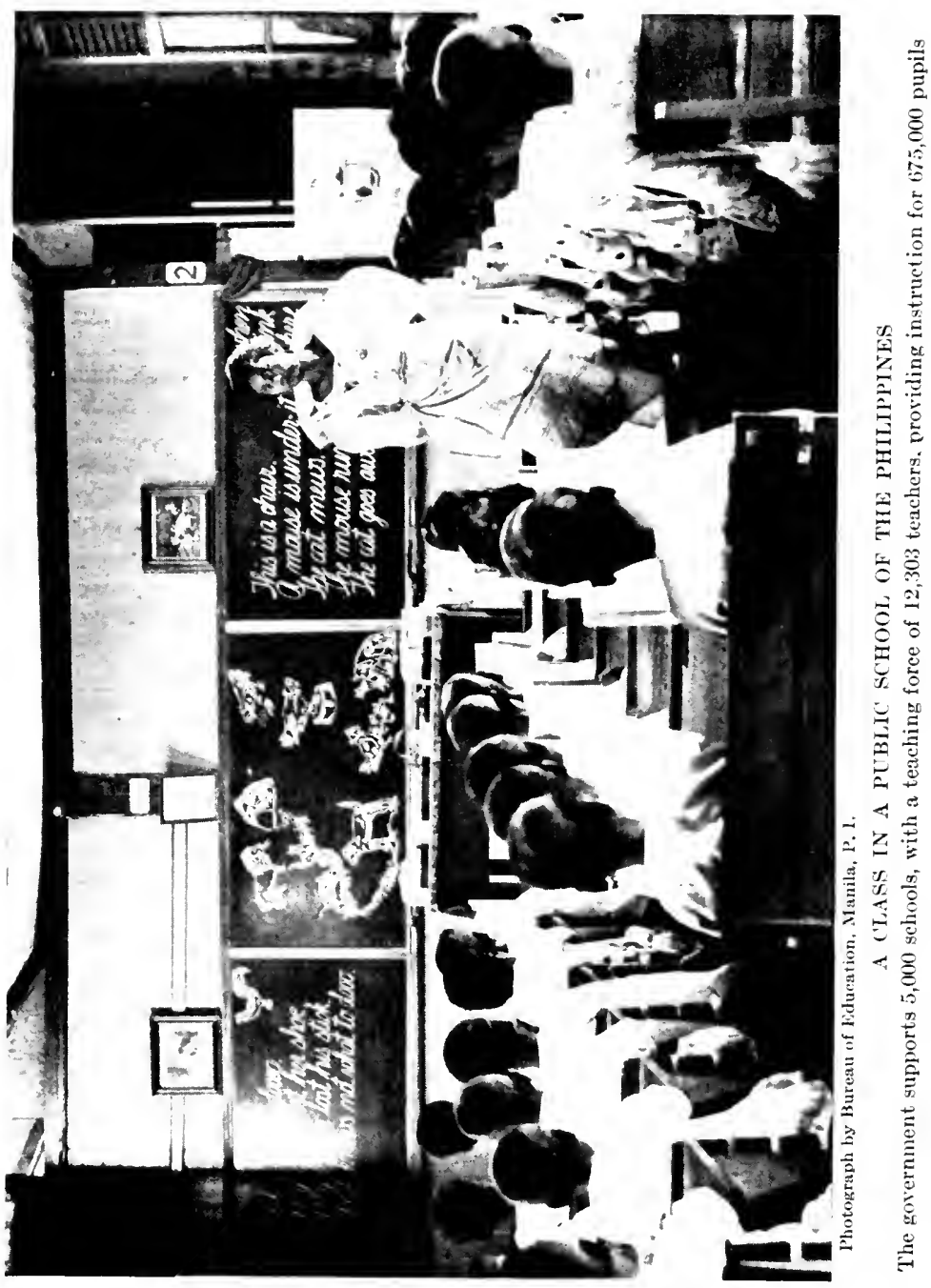




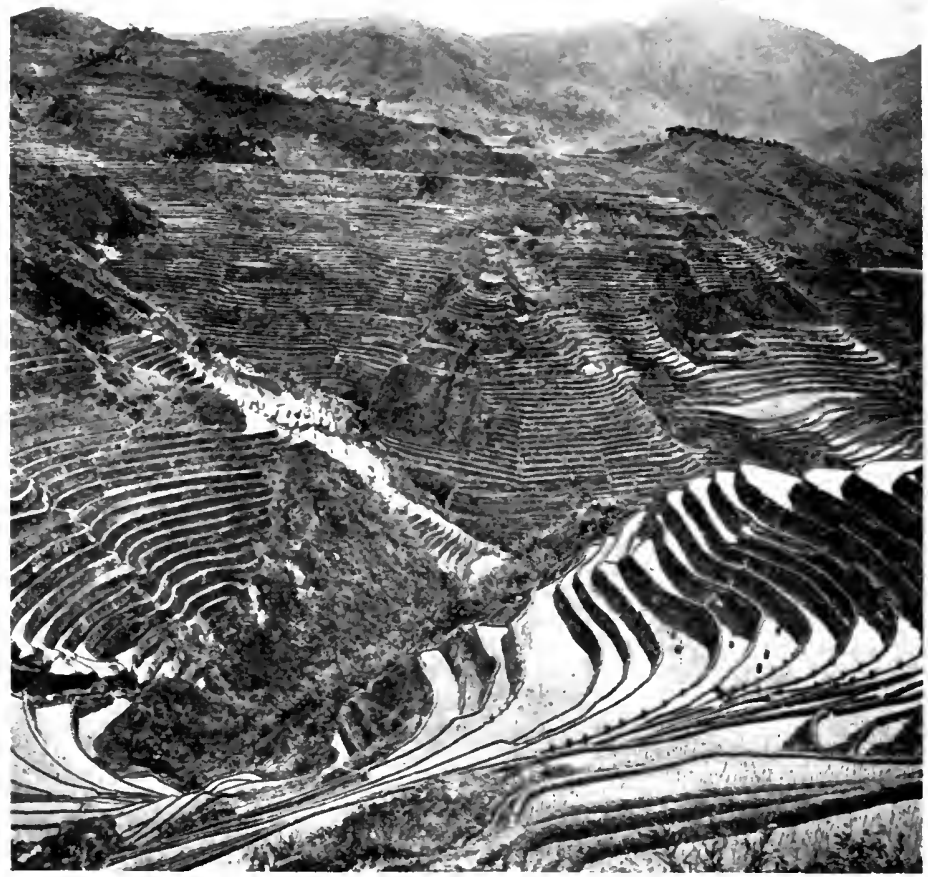

IFUGAO IGORRO'T RLCE TERRACES

Among the most remarkable of their kind in the world. It is estimated there are 12,121 miles of s-feet stone walls in the Ifugao terraces, which is approximately half the distanee around the world. These terraces are skillfully irrigated by water brought in trovghs or in clitehes along the precipitous mountain sides over long distanees 
awakened national consciousness to secure for themselves and their posterity the means of their happiness and prosperity. The growth of the public school system in size and in efficiency has been accompanied by the placing of more responsibility upon the shoulders of Filipinos. Several years ago Filipino teachers began to give all primary instruction and they now do ninety-eight per cent of the teaching of intermediate grades and forty-four per cent of that of secondary grades. Administrative and supervisory positions have also been opened to them. Eighty-six per cent of the 350 supervising teachers are Filipinos and they hold the majority of the positions of academic and industrial supervisors. Five Filipinos are division superintendents and one is the Second Assistant Director of Education. Such an acceptance of responsibility within a comparatively few years is both an indication of the interest of the Filipinos in education and of their ability to succeed in the professional work of teaching and supervision.

By Act 2156, as amended, provinces and municipalities have been enabled to organize themselves into sanitary districts and divisions. At present there are 32 provinces organized into 
sanitary districts with a total of 252 sanitary divisions, and two provinces (Ambos Camarines and Romblon) in each municipality of which a municipal board of health is organized. There are 220 doctors employed as municipal health officers, 26 nurses and 815 sanitary inspectors. This organization has been productive of great beneficial results to provinces and municipalities and their inhabitants. Thereby, the people have come in closer contact with the health officials, and with the cooperation of the provincial and municipal officials and the people in general, epidemic outbreaks have oftentimes been avoided or easily brought under control.

Magnificent first-class roads connect many provinces and municipalities, and the difficulty of communication of former years is now hardly felt. With approximately 15,000 kilometers of good roads, bridges and ferries, built and constructed during the last five years at a cost of 19,724,959.60 pesos, travelers and tourists may now travel in safety from one province to another and admire the beautiful scenery across mountains, plains and verdant fields.

Numerous provincial and municipal buildings have been built, the total amount spent for the construction of the former being $1,675,274.38$ 
pesos, and of the latter $5,859,013,62$ pesos. Numerous modern sanitary markets and slaughterhouses have likewise been constructed, the total expenditure therefor being $3,291,315.66$ pesos. The total number of artesian wells built to the present time is 893 , at a cost of approximately $3,000,000.00$ pesos. These have solved many of the vexing health problems that formerly existed, and have contributed largely to the prevention of a high rate of mortality.

It will be seen from the foregoing brief statements that during the last five years, provinces and municipalities have increased; that the Philippine Legislature has passed laws calculated to make provincial and municipal governments more popular and autonomous; that the Filipinos have gradually assumed control over provincial and municipal administration; that the provincial and municipal officials have shown improvement, capacity and integrity in the administration of provincial and municipal affairs; that the provinces and municipalities have improved financially, and that they have willingly and effectively met the aspirations and needs of their inhabitants.

It is vain to theorize on the success attained by the Filipinos in provincial and municipal ad- 
ministration during the last five years. Suffice it to say that they have made the largest, ablest and wisest use of the functions entrusted to them. They have demonstrated that they are wholly capable of playing their part in the conduct of their affairs with skill, dignity, firmness, and above all, with unswerving loyalty to the ideals of their country.

If the progress achieved by the Philippine Islands during the last five years is to be determined by the progress made by provinces and municipalities during that period, the Philippine Islands have indeed advanced wonderfully. She has had an accomplishment which any nation can be proud of. Her people have seen schools multiply in remote barrios, and knowledge of hygiene and sanitation penetrate into the most remote communities. They have seen the roads thread their way through every province, transforming poverty-stricken regions into rich and flourishing communities. All these have brought to the Filipino people a sense of unity and have turned out a well-educated citizenry worthy of their race. The Filipino people have witnessed the transfer of government into their hands and have handled it in a manner creditable to themselves and their country. 


\section{CHAPTER VII}

OUR TREATMENT OF THE NON-CHRISTIAN TRIBES

NE of the strongest objections to the independence of the Philippines has been the so-called non-Christian problem. According to the census estimate of 1918 , out of the population of $10,500,000$ Filipinos, there are 500,000 inhabitants who belong to the so-called non-Christian tribes. The most numerous of these non-Christian people are the Moros, who inhabit the Sulu Archipelago and certain parts of Mindanao. The Mountain Province and Nueva Vizcaya, in Luzon, contain also nonChristian people. It was predicted that with the establishment of Philippine autonomy the Moros would revive their piratical life and war on their Christian brothers and that the other districts would be subject to disorders and revolutions. Nothing of the sort has developed.

Unlike the backward peoples in other parts of the globe, the non-Christian peoples of the Philippines have always received humanitarian 
treatment from the American Government as well as from their Christian brothers. From 1913 to 1916 the non-Christian peoples were under the exclusive control and jurisdiction of the Philippine Commission composed of a majority of Filipinos. Since the passage of the Jones Law in 1916, the Philippine Legislature, composed entirely of Filipinos, assumed legislative control of the non-Christian tribes. Since 1913, therefore, the representatives of the Christian Filipinos have dictated the policy pursued toward their non-Christian brothers, and a review of what has been done since that time would give us an insight as to our treatment of the problem.

The Philippine Commission and the Philippine Legislature have expressed unequivocally by appropriate legislation their policy towards the non-Christian peoples. Such a policy has for its fundamental objective the establishment and promotion of friendly relations with the nonChristian people of the Philippine Islands and the promotion of their agricultural, industrial and economic development and their advancement in civilization. (See, among others, Acts Nos. 2208, 2404 and 2444.)

Upon the establishment of the Bureau of nonChristian tribes by section 22 of the Jones Law, 
the Philippine Legislature on February 20, 1917, enacted Act No. 2674 providing for the operation of said bureau. That law defines in a clear and unequivocal term the policy of the Government towards the non-Christian people as follows:

". . . to foster by all adequate means and in a sys. tematic, rapid and complete manner the moral, material, economic, social and political development of the regions inhabited by non-Christian Filipinos, always having in view the aim of rendering permanent the mutual intelligence between and complete fusion of all the Christian and non-Christian elements populating the provinces of the Archipelago."

The Secretary of the Interior, who is the official charged with the supervision and control of all the non-Christian people, has, consistently with law, adopted the following program of administration with regard to those people:

The advancement of the non-Christian elements of our population to equality and unification with the highly civilized Christian inhabitants. This is carried on by the adoption of the following measures:

(a) Pursuance of the closer settlement policy whereby people of semi-nomadic race are induced to leave their wild habitat and settle in organized communities. 
(b) The extension of the public school system and the system of public health throughout the regions inhabited by the non-Christian people.

(c) The extension of public works throughout the Mohammedan regions to facilitate their development and the extension of government control.

(d) Construction of roads and trails between one place and another among non-Christians to promote soeial and commercial intercourse and maintain amicable relations among them and with the Christian people.

(e) Pursuance of the development of natural economic resources, especially agriculture.

(f) The encouragement of immigration into, and of the investment of private capital in, the fertile regions of Mindanao and Sulu.

The foregoing program is for all non-Christians in every part of the Philippines. In 1914 the United States military forces ceased to control the parts of Mindanao and Sulu inhabited by the non-Christians, and these were then created into the Department of Mindanao and Sulu under a civil governor. Philippine constabulary soldiers composed mostly of Filipinos were sent down to keep order. But soldiers are not the main factors of the policy of the civil government. With them went Filipino teachers, doctors, and nurses to preach, in words as well as in deeds, the gospel of brotherhood and civil- 
ization. The non-Christian peoples are now being taught and guided to improve their living conditions in order that they may fully appreciate the benefits of civilization. Those of them who are still given to nomadic habits are being persuaded to abandon their wild habitats and settle in organized settlements. They are being made to understand that it is the purpose of the government to organize them politically into fixed and permanent communities, aid them to live and work, protect them from involuntary servitude and abuse, educate their children, and show them the advantages of leading a civilized life on a par with their civilized brothers.

To assure the success of the work, the organization and extension of public schools throughout the non-Christian territory has been given special emphasis. Among the Moros of Mindanao and Sulu, as in other parts of the Islands, the first instruction in the English language was given by American soldiers detailed as teachers. The army foresaw the advantages of public schools from a military viewpoint. As early as 1903 primary schools were organized in a few of the principal villages where Arabic and English were taught. However, in view of the newness of the ideas and the distrust of the Moros 
and other non-Christians, very little progress was made in establishing and maintaining public schools. At the end of the school year 19031904, they had an attendance of only 1,582 pupils, and by 1913 , at the end of the military rule in Mindanao and Sulu, there was an attendance of only 4,535. The last five years, in which the Filipinos controlled the legislative policy towards the Moros, the educational progress has been tremendous. The following figures show the average daily attendance and the expenditures for public education for the Moro provinces from 1912 to the present time:

$$
\begin{array}{ccc}
\text { Fiscal year } & \begin{array}{c}
\text { Average Daily } \\
\text { Attendance }
\end{array} & \text { Expenditures } \\
1912 & 3,807 & \mathrm{P} 93,987.00 \\
1913 & 4,535 & 137,069.00 \\
1918 & 16,114 & 650,000.00 \text { (Estimate) }^{1}
\end{array}
$$

Act 2531 passed by the Philippine Legislature under date of October 26, 1915, gave great impetus to educational work in the non-Christian provinces. This act appropriated the sum of P1,000,000 for expenses of the Bureau of Education necessary for the construction, establishment, organization, and operation of additional

1 I am indebted for this school data to Dr. W. W. Marquardt, Director of the Bureau of Education. 
free insular primary schools in the territory inhabited by Mohammedans or other non-Christian Filipinos, and to make the necessary provisions for normal training of teachers for said primary schools. This fund was allotted in proportion to the school population, and was used for the purchase of sites, construction of buildings, purchase of equipment, and for current expenses, such as salaries and supplies. This million pesos was a direct contribution of the Christian population to their non-Christian brothers; for our non-Christian population is far from being self-supporting, and millions of pesos have to be taken every year from the pockets of the Christian people for the uplift of their backward brothers. This fact must not be lost sight of in the discussion of the nonChristian problem.

Special effort has been made to so frame the courses of study that they may meet the peculiar needs of each of the non-Christian people. Settlement farm schools have been established to meet the particular needs of more or less nomadic tribes. Boarding schools are established wherever economic conditions demand it. It has been found that the only practical way to reach the non-Christian girls is through dormitory 
schools. Loom-weaving is being taught to girls in a few schools. The industrial work prescribed for these people, however, has been limited very largely to agriculture for boys and plain sewing for girls.

The number of teachers in the Mountain Province in 1912 was 93 . The number of teachers assigned to this work at the present time (1918) is 251. The number of teachers in Nueva Vizcaya in 1912 was 64. At the present time there are 87 teachers on duty there. The number of teachers in the Department of Mindanao and Sulu in 1912 was 99. At present there are 783 teachers assigned to this department. A great many of these teachers have come from the Central Luzon Agricultural School, but almost every province in the Philippine Islands is represented. The willingness of these teachers to leave their homes and take up work in the nonChristian provinces is a significant development in education and in the problem of final unification and nationalization of the people of the Philippines. During the past year the attend. ance in the non-Christian provinces has almost doubled. The schools in the northern part of Luzon and also in Mindanao are fitting boys for farm work by giving them a fundamental knowl- 
edge of agriculture and by teaching them how to work. Girls are taught plain sewing so that they may provide their own clothes, and weaving and other minor industries so that they may earn a livelihood.

Side by side with the extension of the public schools has gone the extension of the public health service. In 1914 the health and school authorities of the Department of Mindanao and Sulu undertook the establishment of combination schools and dispensaries. These institutions, seventeen of which have already been established, are in charge of the School of Nursing of the University of the Philippines. The salaries of the teachers in these combined institutions are paid in equal parts from health and school funds. These institutions are for the most part located in remote communities and make a strong appeal to the non-Christian people. Approximately 30,000 children are treated each year in these dispensaries. In addition to the school dispensaries mentioned above, there are nine special dispensaries maintained wholly by the school department. The teachers in charge of these dispensaries receive a course of instruction in dispensary work at the normal institutes. In order to train teachers for this work, a graduate 
nurse has been assigned to the Zamboanga Normal School where she is conducting a course for students who are preparing themselves to become teachers. In this connection it must be said that kind treatment and modern medicine have proven greater civilizing factors than bayonets and Krags. The most prominent citizen of the Moro people, Senator Hadji Butu, tells how a physician, Dr. Sixto Orosa, has won the affection of his people. He says, "All the Moros like him; many come from the mountains to ask medicine from him. Before he came they were afraid to drink hospital medicine and to stay in the hospital. But now they have proved that Dr. Orosa's medicines cure quickly and his operations are not painful and the wounds heal in a short time, so they have full confidence in him. All the Datos and Chiefs of Sulu want Dr. Orosa to stay in Jolo all the time, as they regard him with positive affection."

Of no less importance than the public health work is the extension of public works throughout the Mohammedan, pagan and other nonChristian regions to facilitate their development and the extension of government control. This was a new policy, for during the time that the military anthorities controlled Mindanao and 
Sulu no permanent road construction of any kind was done, with the exception of the road from Camp Overton to Camp Keithley in Lanao and another connecting the town of Zamboanga with the San Ramon penal colony. As soon as the Christian Filipinos gained control of the legislature a vigorous policy of extending the public works throughout the non-Christian parts of the Islands was begun. Special attention was given to the construction and maintenance of roads and trails, the improvement of ports and landing facilities, the extension and maintenance of telephone lines and a portable water supply, the removal of obstacles to navigation of rivers, and the construction and maintenance of public buildings, especially schools and hospitals. The sub-provinces of Agusan, Bukidnon, Cotabato, Davao, Lanao, Sulu and Zamboanga of the Department of Mindanao and Sulu, are all receiving the benefits of this public-works program. It will be only a question of time when they will have just as good roads as the parts inhabited by the Christian Filipinos.

Then we have activities in connection with the natural resources of the non-Christian parts. Graduates of the College of Agriculture are yearly being sent in numbers to teach the Moro 
people the modern methods of farming. A policy of immigration has been undertaken whereby Christian citizens from the densely populated parts of the Islands may, with government help, immigrate to the virgin fields of Mindanao and Sulu and establish themselves side by side with their non-Christian brothers. For the year 1917 the Philippine Legislature appropriated 100,000 pesos "for aid to such inhabitants of the provinces of Luzon and the Vizcayas as may desire to settle in Mindanao and Sulu, either in order to take advantage of the public-land act by purchasing public land or acquiring the same under the homestead provisions of said act, or for the purpose of taking employment as laborers on private plantations or public works, including propaganda and transportation expenses." The object of these agricultural colonies was not only the develop. ment of the vast fields that have not yet been touched by the hand of man, but also the amalgamation of Christian and Mohammedan Filipinos. In laying out the plans of these colonies the government saw to it that a Christian Filipino had a Moro for a neighbor. This arrangement was predicted by some as dangerous and ill-advised, but the undertaking is now considered a success 


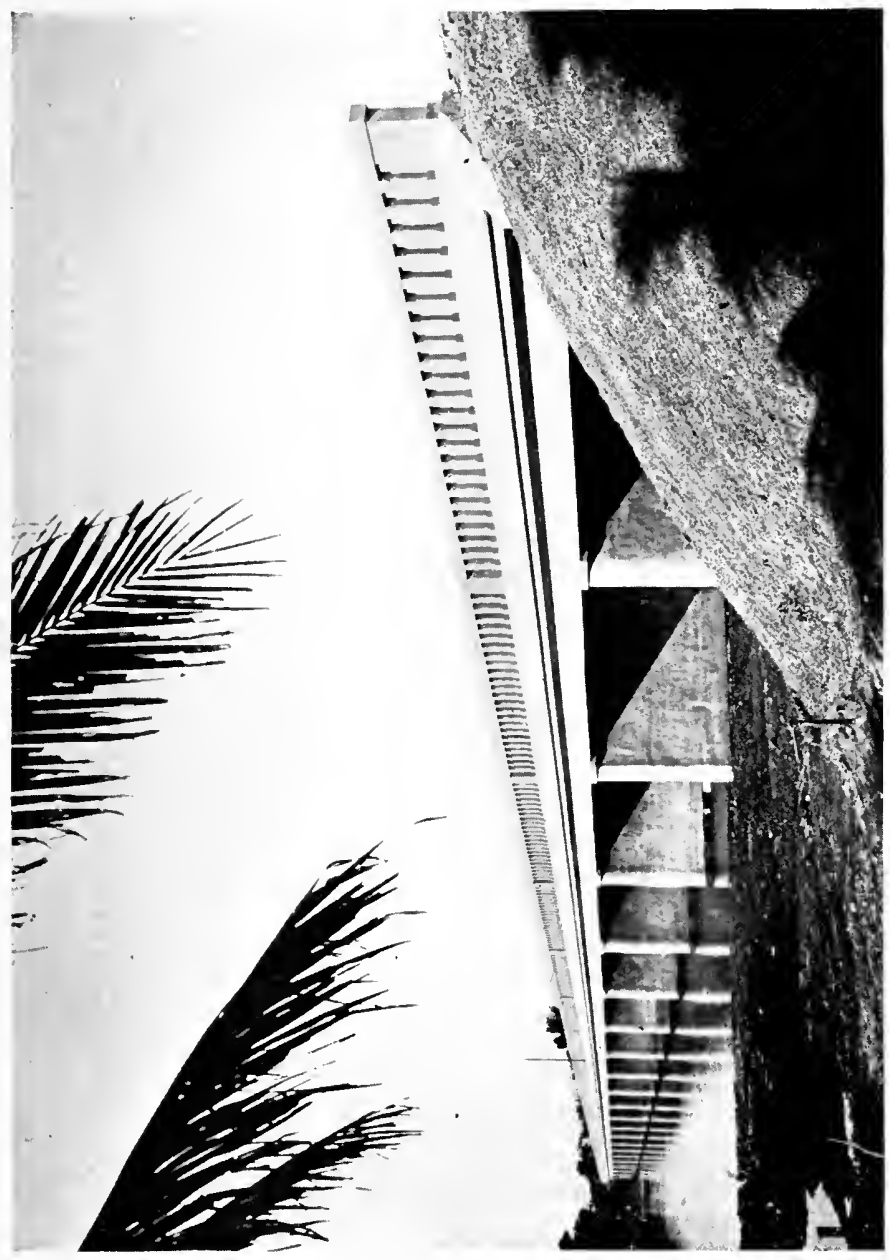

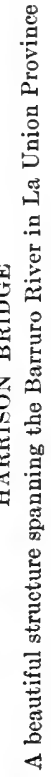




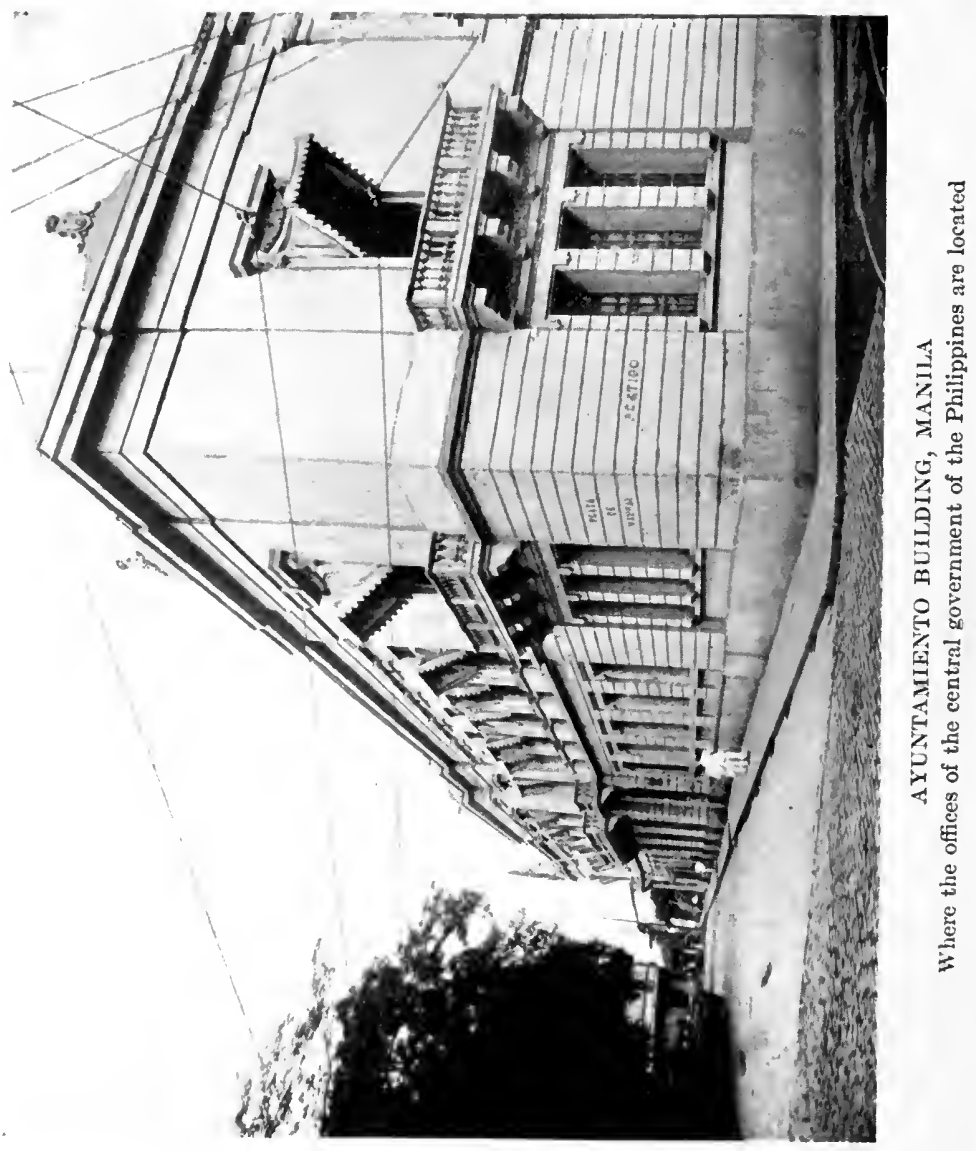


even by those who were at first most pessimistic and adverse opponents of the plan. Once more it was proven that Moros and Christian Filipinos can live harmoniously together, for they are in truth citizens of one country and members of one race.

But possibly the most difficult task of the government has been the separation of Church and State in the Moro country and the relinquishment of civil authority by the native chiefs in favor of the agents of the central government. In no other Mohammedan country has this ever been attempted. From time immemorial governmental authority has been exercised by the prelates and clergy of the Mohammedan Church in Sulu, Cotabato, Lanao, a large part of Zamboanga, and in those portions of the provinces of Bukidnon and Davao which are inhabited by Mohammedans. Naturally, every feature of the extension of government control with its consequent tendency to reduce the authority and perquisites of the Mohammedan clergy and their patrons, the datus, is always made the subject of petition and oral protests, oftentimes couched in the most vigorous and insistent terms, by the people to the authorities. The separation of Church and State, always a complex and delicate 
undertaking, is a specially difficult matter requiring the exercise of the utmost patience and tact by local officials in our Mohammedan territory. The activities of government control, such as the public land surveys and the implantation of the system of taxation, which are new to our Mohammedan territories, arouse suspicion as to their ulterior objectives.

Yet, despite these serious obstacles which militated against the complete extension and recognition of government authority, the policy of the central government has been crowned with tremendous success. The Sultan of Sulu has formally renounced his claim to sovereignty over his Mohammedan subjects in favor of the civil government. Peace and public order have been kept in excellent condition as elsewhere in the Archipelago. Colonel Ole Waloe, commanding the constabulary in the Department of Mindanao and Sulu, in a brief memorandum to the Department Secretary dated November 23, 1918, says :

"1. As late as 1885, the Spanish Government pardoned Datu Pedro Cuevas and his gang of escaped convicts on condition that they protect the town of Isabela, Basilan, from further attacks from the Joloano 
and Yakan Moros, notwithstanding the place was at that time protected by an excellent fort.

“2. In 1904 this same Datu Cuevas wrote the Governor that he had captured three pirates and, after investigating them, had had them shot.

"3. During 1908, no less than six different outlaw bands operated at various times during the year on Basilan in such force and with such daring that it was necessary to send four companies of U. S. Infantry and two companies of constabulary to that island.

"4. For the years 1908-1909, thirty-seven outlaws were reported killed, captured and wounded. For 1910-1911, twenty-eight. For 1912-1913, forty. For 1914, twenty-three. For 1915, one, and for 1916-1917, none. This great change from a spirit of outlawry and piracy, coming down from the Spanish régime, to peace and industry, was brought about almost entirely by the sympathetic attitude and friendly interest of the Department Government toward the Moros and pagan tribes of the province. Force without limit had been used for three hundred years, but apparently with little, if any, permanent results.

"5. For the last four years, the number of grave crimes occurring in the province of Zamboanga have been less than those in the Department's most advanced Christian province for the same period.

"6. The Moro is no more the blood-thirsty religious fanatic of a few years ago, but is aiding us to a remarkable degree in maintaining law and order. In fact our success in dealing with Moro outlaws has been 
due almost entirely to the loyal support and aid we have received from the great majority of the inhabitants of the districts affected. The Moro is industrious and a good farmer to the extent of his agricultural knowledge. He is beginning to see the advantages of education, to have respect for his Christian brother and be more tolerant in his religious views. $\mathrm{He}$ is, however, proud of his history and loyal to his religion, but commerce and education are rapidly widening his horizon.

"The juramentado is a thing of the past, while there has been only one amuck in the province of Zamboanga during the last eighteen years. This misguided being was probably suffering from an attack of temporary insanity, as he imagined that his mother-in-law had administered poison in his food; after brooding over the matter a few days he decided to commit suicide in the old Moro fashion, namely by running amuck. "Contrary to the prediction of the calamity howlers, the Christian Filipino officers of the constabulary have succeeded completely in winning the respect and confidence of the Moro.

"7. The pagan tribes of the province, Subanos and Yakans, have never been headhunters nor made human sacrifices. On the other hand, they have given very little trouble, except when led on by outside malcontents that took refuge among them when pursued by the law. They are peaceable, industrious farmers and hunters by nature, and, under the present system of governmental supervision, are rapidly taking up homesteads and settling in the low lands. This, of course, 
is not only of great benefit to themselves, but simplifies the problem of law and order and creates a supply of labor for the future development of the country.

" 8 . The practice of appointing constabulary officers deputy governors in Moro and pagan districts has not only greatly facilitated the maintenance of law and order in those sections, but has aided us much in our efforts to get the pagan tribes out of the hills and settled in villages in the low lands. Furthermore, concentration of authority is in line with their notions of government, and it is believed more completely meets their present needs."

The foregoing testimony of an American official is one of the most eloquent proofs of the success of our policy towards the non-Christian tribes.

The Jones Law also brought a new era among the non-Christian people. For the first time they were given representation in the National Legislature. Seven out of the ninety members of the Lower House and two out of the twentyfour members of the Senate were to be appointed to represent the non-Christian peoples of the Islands. As a result of this arrangement, three prominent Moros and two pagans received the appointment. The most conspicuous citizen of the Moro people, Hadji Butu Baki, was appointed Senator, and Datu Piang and Datu 
Benito were appointed Representatives. Their appointment was received with great satisfaction by the Moro people, and for the first time in the history of the Philippine Islands, the Mohammedan Filipinos sat side by side with the Christian Filipinos in the legislative halls to work out the destinies of their common country. Senator Butu and Representatives Benito and Piang were granted the special privilege of taking the oath of office on the Koran. This act of the Senate and House of Representatives was looked upon by the representative Mohammedans present at the inauguration as assurance of an attitude of religious tolerance and respect on the part of the Christian Filipinos. It was not considered a mere courtesy, but rather a guarantee of non-interference in their religious affairs.

Coincident with the inauguration of the Philippine Congress there were presented significant memorials indicative of the feeling of confidence and love which the Moro people have for their Christian brothers. These memorials were addressed to both houses of the Legislature, through the Governor-General, signed by the Sultan of Sulu and the most important and influential Datus in the Sulu Archipelago, Cotabato and Lanao and Zamboanga Provinces, rep- 
resenting all classes of Mohammedans in Mindanao-Sulu, expressing their gratitude for material benefits and political privileges afforded Mohammedans during the past three years, and also for the liberal appropriations for public schools, health, and public works, and for the representation in both houses of the Philippine Legislature granted under the new Organic Act for the Philippine Government. The memorials also expressed the hope that the administration would continue to strengthen the existing close relations between all the people of the Philippine Islands. ${ }^{1}$

Such, in brief, has been our policy towards the non-Christian peoples. It is acknowledged by all unbiased observers as a decided success. It is an unprecedented treatment of non-Christian peoples by their more civilized fellow men, who, by sheer number, strength and superior civilization, could, under recognized practices, claim to be the sole owners of the country. You can now travel from one end of the Moro region to the other in safety. The schools have brought the standard of the Moro people nearer that of their Christian brothers. Teachers, doctors and

1 From a recent report by Governor Frank W. Carpenter, of the Department of Mindanao and Sulu. 
nurses from all over the Islands have carried a message of friendship and love and have established more firmly the national solidarity of Christians and non-Christians than the severest policy of blood and iron would have done. The respect that the Christian Filipinos have shown towards the religion of the Moros has inspired them with renewed confidence. The participation that the Moro people were given in national law-making bound them closer still to Christian Filipinos. "We are one in spirit and one in blood," says Senator Hadji Butu.

Upon the establishment of the Philippine Republic the world will certainly find the nonChristian Filipinos as enthusiastic supporters of its independence as their Christian brothers. 


\section{CHAPTER VIII}

A STABLE GOVERNMENT ESTABLISHED

"T $T$ is, as it has always been, the purpose of 1 the people of the United States to withdraw their sovereignty over the Philippine Islands and to recognize their independence as soon as a stable government can be established therein." Thus runs the fundamental pledge of the American people to the Filipino people. The independence of the Philippines is to be recognized "as soon as a stable government can be established therein." But what does America mean by a stable government?

The phrase "a stable government" is not, as has been claimed by some, vague and ambiguous. It has a definite meaning in American international law, especially in the history of America's relations with weak countries struggling for independence. It was not the first time that the American Government used the phrase in connection with the recognition of new states. When in 1875 there was considerable agitation in 
the United States to recognize the independence of the Cubans, struggling to shake off the Spanish yoke, President Grant, in his message to Congress, expressed the idea that not until the Cuban people had set up a government "possessed of the elements of stability" could recognition be possible. Quoting his own words :

"Where a considerable body of people, who have attempted to free themselves of the control of the superior government, have reached such point in occupation of territory, in power, and in general organization as to constitute in fact a body politic, having a government in substance as well as in name, possessed of the elements of stability, and equipped with the machinery for the administration of internal policy and the execution of its laws, prepared and able to administer justice at home, as well as in its dealing with other powers, it is within the province of those other powers to recognize its existence as a new and independent nation."

Elucidating further what he meant by such a government, he said :

"To establish the condition of things essential to the recognition of this fact, there must be a people occupying a known territory, united under some known and defined form of government, acknowledged by those subject thereto, in which the functions of gov- 
ernment are administered by usual methods, competent to mete out justice to citizens and strangers, to afford remedies for public and for private wrongs, and able to assume the correlative international obligations and capable of performing the corresponding international duties resulting from its acquisition of the rights of sovereignty."

President McKinley, when confronted with the same problem of the recognition of Cuban independence, quoted the very words of President Grant, saying:

"The United States, in addition to the test imposed by public law as the condition of the recognition of independence by a neutral state (to wit, that the revolted state shall 'constitute in fact a body politic, having a government in substance as well as in name, possessed of all the elements of stability,' and forming de facto, 'if left to itself, a state among the nations, reasonably capable of discharging the duties of a state'), has imposed for its own goverument in dealing with cases like these the further condition that recognition of independent statehood is not due to a revolted dependency until the danger of its being again subjugated by the parent state has entirely passed away."

In the recognition of foreign governments, the conditions imposed by the United States before such recognition could be granted, were 
merely conditions of fact - whether the government which desired to be recognized was a de facto government, actually independent from the mother country. It did not matter whether such a government had been established legally or not. When Mr. Adams was Secretary of State, the question of recognizing the independence of Venezuela was taken up, and he said:

"There is a stage in such contests when the parties struggling for independence have, as I conceive, a right to demand its acknowledgment by neutral parties, and when the acknowledgment may be granted without departure from the obligations of neutrality. It is the stage when independence is established as a matter of fact so as to leave the chances of the opposite party to recover their dominion utterly desperate. ... I am satisfied that the cause of the South Americans, so far as it consists in the assertion of independence against Spain, is just. But the justice of the cause, however it may enlist individual feelings in its favor, is not sufficient to justify third parties in siding with it. The fact and the right combined can alone authorize a neutral to acknowledge a new and disputed sovereignty. The neutral may, indeed, infer the right from the fact, but not the fact from the right.

"In every question relating to the independence of a nation two principles are involved, one of right and the other of fact: the former exclusively depending upon the determination of the nation itself, and the 
latter resulting from the successful execution of that determination.",

A similar exposition of the American theory was stated by President Jackson in his message of December 21, 1836, upon the question of recognizing the independence of Texas. He said:

". . . All questions relative to the government of foreign nations, whether of the Old or New World, have been treated by the United States as questions of fact only, and our predecessors have cautiously abstained from deciding upon them until the clearest evidence was in their possession to enable them not only to decide correctly, but to shield their decisions from every unworthy imputation. . . .

"It has thus made known to the world that the uniform policy and practice of the United States is to avoid all interference in disputes which merely relate to the internal government of other nations, and eventually to recognize the authority of the prevailing party without reference to our particular interests and views or to the merits of the original controversy. Public opinion here is so firmly established and well understood in favor of this policy that no serious disagreement has ever risen among ourselves in relation to it, although brought under view in a variety of forms and at periods when the minds of the people were greatly excited by the agitation of topics purely domestic in their character. Nor has any deliberate 
inquiry ever been instituted in Congress or in any of our legislative bodies as to whom belonged the power of originally recognizing a new state. ..."

These views were again corroborated and repeated by President McKinley in his message of April 11, 1898.

Following the foregoing principles, the South American republics were one by one recognized as soon as they had shown that they had a government exercising all governmental functions without the possibility of its being reconquered by the sovereign state. It was not required even that the governments so recognized should be a republic or an empire, for the empire of Brazil was recognized in the same way that republics were recognized.

The elements of stability of which President Grant spoke and which were re-echoed by President McKinley only meant a de facto government supported by the people. But the more pertinent precedent for the Philippines is the case of Cuba. The United States had required of Cuba the establishment of the very same kind of government which she now requires of the Filipino people - a stable government - before final recognition was given to the Cuban Republic. It may be recalled that the misery and starvation of 
the Cuban people under the hands of the Spanish government and the desire to establish a stable government in Cuba was the prime cause of the Spanish-American War. In his message to Congress of April 11, 1898, depicting what was happening to Cuba and what America should do, President McKinley said :

" The only hope of relief and repose from a condition which can no longer be endured is the enforced pacification of Cuba. In the name of humanity, in the name of civilization, in behalf of endangered American interests which give us the right and the duty to speak and to act, the war in Cuba must stop.

"In view of these facts and of these considerations I ask the Congress to authorize and empower the President to take measures to secure a full and final termination of hostilities between the Government of Spain and the people of Cuba, and to secure in the island the establishment of a stable government capable of maintaining order and observing its international obligations, insuring peace and tranquillity and the security of its citizens as well as our own, and to use the military and naval forces of the United States as may be necessary for these purposes."

As a result of the war, Spain was obliged to withdraw her sovereignty from Cuba. The American Government occupied the Island temporarily and proceeded to establish a stable gov- 
ernment. The first step was the taking of a census to ascertain the political capacity of the people. It was found that "sixty-six per cent of the inhabitants of the Islands could not read and write" (a much higher per cent than in the Philippines), and a limited suffrage was therefore established based on the same conditions as those in the Philippine Islands, except that those who had serred in the Cuban army were allowed to rote. After the census was taken, a provisional law was ordered by the military governor, General Wood, to hold municipal and provincial elections. Then the same voters who voted in the municipal and provincial elections were called upon to elect the members of a constitutional convention which was to draft a Con. stitution for Cuba. The Military Governor opened the convention and, by direction of the Secretary of War, said, among other things:

"It will be your duty first to frame and adopt a constitution of Cuba . . adequate to secure a stable, orderly and free government."

To explain further what was meant by a "stable, orderly and free government" when the convention appeared to be drawing near the conclusion of its constitution-drafting, Secretary Root 


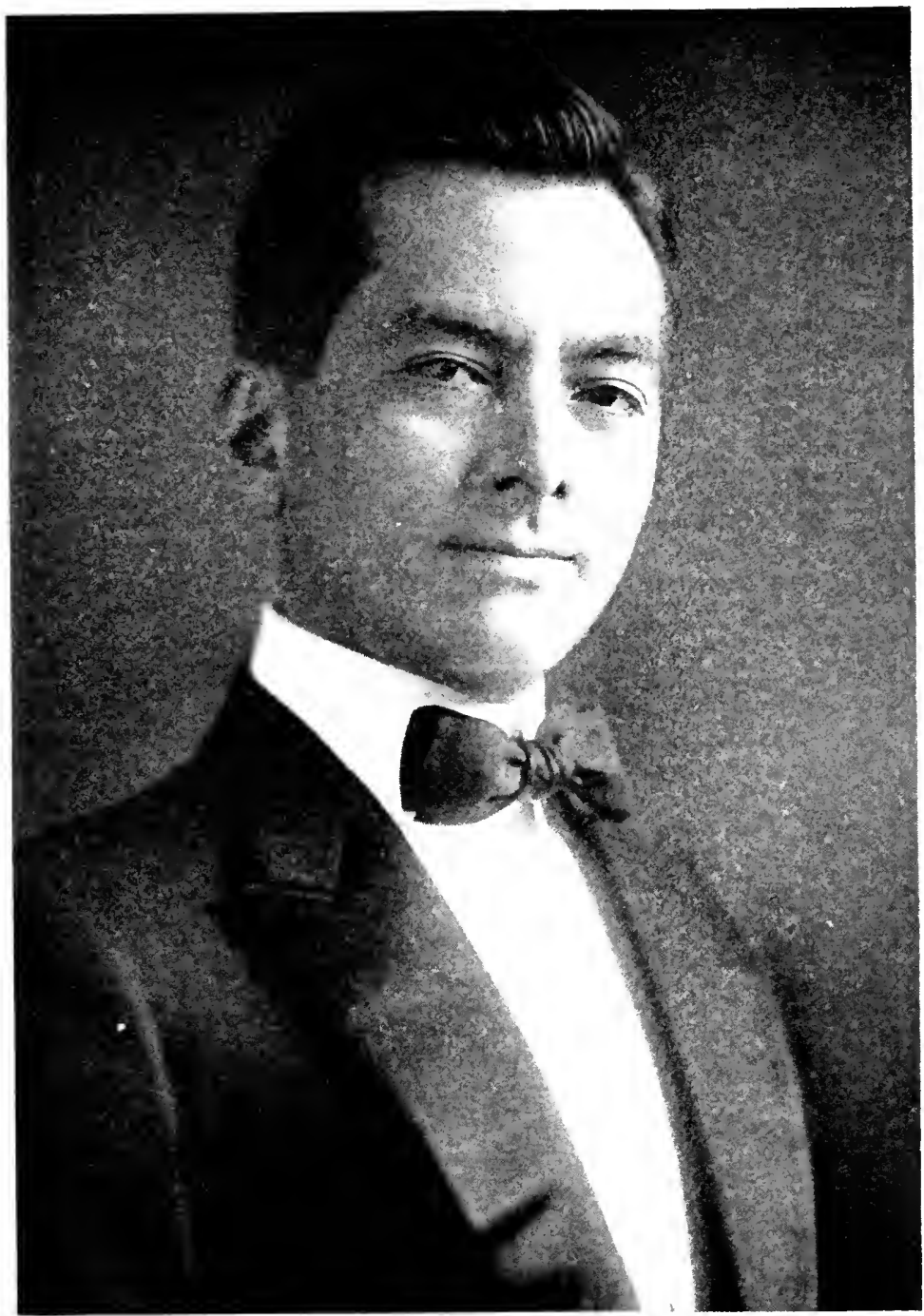

(C) Harris \& Ewing

THE HONORABLE MANLEL I. QUEZON

President of the Philippine senate and Chairman of the Philippine Mission to the United States 


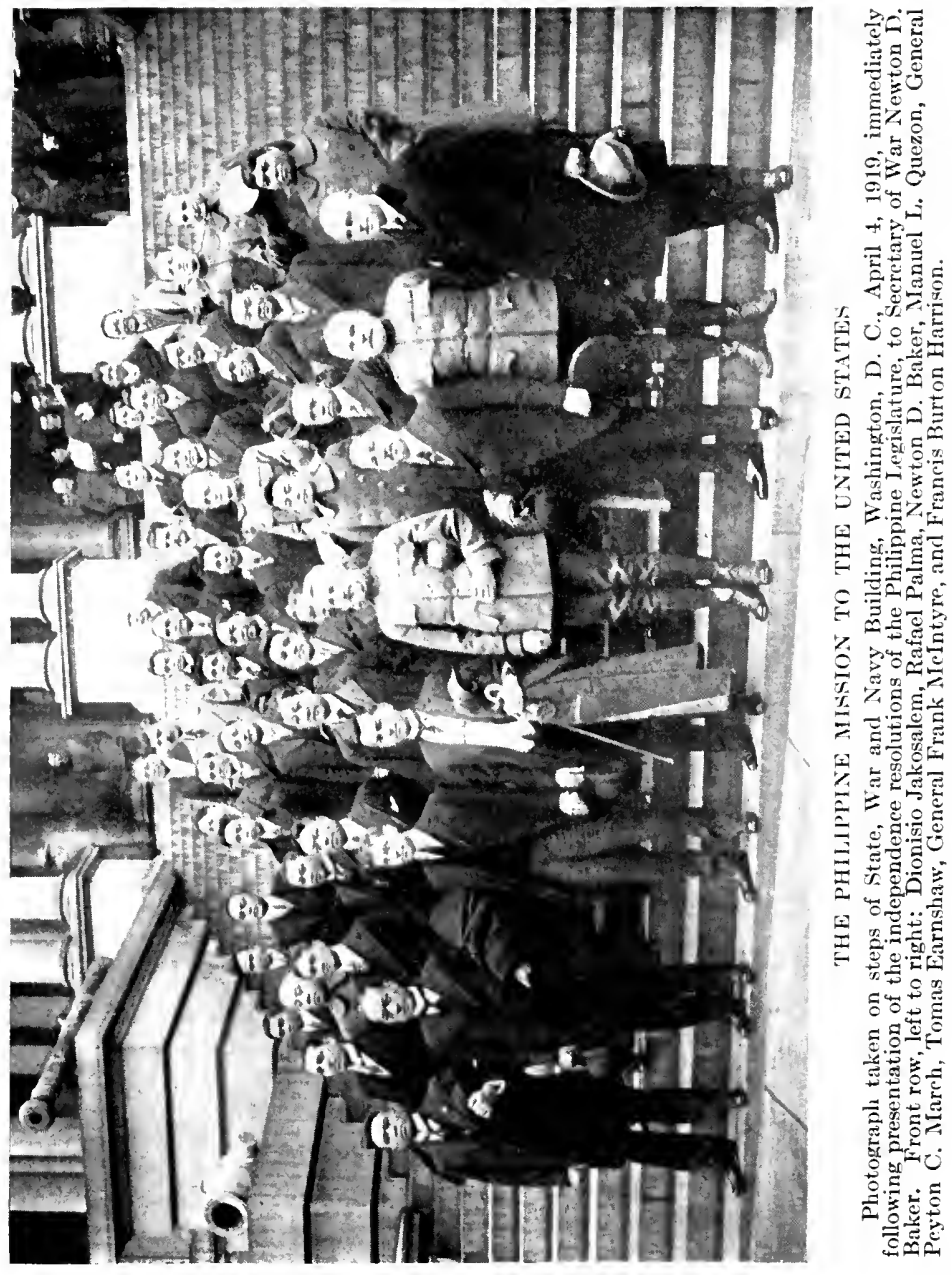


again sent instructions to the Convention through the Military Governor of Cuba. Mr. Root then said :

". . It is plain that the government to which we were thus to transfer our temporary obligations should be a government based upon the peaceful suffrages of the people of Cuba, representing the entire people and holding their power from the people, and subject to the limitations and safeguards which the experience of constitutional government has shown to be necessary to the preservation of individual rights. ...'

An interesting document, the American Government's official account of the establishment of Cuban independence prepared by the War Department and entitled "The Establishment of Free Government in Cuba" (Sen. doc. 312, 58th Cong. 2d Ses.), describes the stable government required of Cuba, in the following words :

"The occupation of the island by the United States being established, it was necessary to enter upon the work of creating and establishing a stable government administered by the Cuban people, republican in form, and competent to discharge the obligations of international relationship and be entitled to a place in the family of nations."

The constitution drafted by the Cuban people 
was not even to the entire satisfaction of Secretary Root, but it was the deliberate work of the representatives of the Cuban people and, therefore, it was considered acceptable. On December 31, 1901, the Cuban people elected provincial governors and councilors, members of the House of Representatives, and presidential and senatorial electors. The presidential and senatorial electors, in turn, met on February 24, 1902, to elect a President, a Vice-President and Senators. After all these officials were duly elected, the American Government prepared to transfer the government into their hands. The condition of stability had been accomplished and on May 20, 1902, the Military Governor, representing the President of the United States, read the fateful instrument which transferred to "the duly elected representatives of the people of Cuba the government and control of the islands," and declared "the occupation of Cuba by the United States and the military government of the islands to be ended."

A stable government has therefore meant in Cuba a government duly elected by the people. This is the unmistakable interpretation given by the American Government in the words "stable government." When in 1906 America was, upon 
the petition of President Palma, obliged to intervene in Cuba and stop the revolution which threatened the downfall of the government, a stable government had again to be established. Secretary Taft, who was then sent to Cuba to act as provisional governor (as General Wood did in $1900-2$ ), found the political situation by no means complimentary to the political capacity of the people. He found that the election conducted by the Cuban people had been a tremendous farce. He said:

“... The registration conducted by the registrars elected at the preliminary election, which began in the first days of October, resulted in a registration of 432,000 voters in the island of Cuba, whereas by no possibility could the total number of voters exceed 300,000 , and, as many of the Liberals did not register, the fraud involved in this registration amounted to an increase of 150,000 names. . . ."

The situation was officially described by the next provisional governor, Judge Magoon, in the following words :

“ Upon President Palma's affiliation with the Moderate party, the policy was adopted of displacing Liberals from official positions - national, provincial, and municipal - throughout the island, filling their places with members of the Moderate party. This embit- 
tered the opposition to the Administration. When the time for elections approached the Liberals made nominations for all the offices and entered upon a vigorous campaign. The Independent Nationals favored the reelection of President Palma, and locally combined with the Moderates. All the powers of the Executive branch of the Government were utilized to secure the success of the Moderate party in the national, provincial, and municipal elections, and measures were taken of such kind and character as to create a belief in the minds of a large number of electors that the laws had been violated, the constitution subverted, the rights of citizens invaded, and the character of the Government changed; in other words, that recourse had been had to unlawful exereise of power and perpetration of gross injustice to such an extent as to vitiate the elections."

So America had again to establish a "stable government" in Cuba. To use Mr. Taft's own words in explaining the plan of the second provisional government, "Cuba must be returned to the Cuban government fairly elected as soon as the condition and the tranquillity of the country will permit and will assure the stability of the government to be established." The work of Governor Wood was again undertaken. The provisional governor saw to it that the Cuban people elected municipal and provincial officials, members of the House of Representatives, Sen- 
ators, a President and a Vice-President. As soon as all these officials were elected and installed in office, Cuba was again restored to the Cuban people - under a stable government.

That this was the same meaning given to the phrase "stable government" as used in the preamble to the Jones Law is very easily demonstrated. The phrase "stable government" was first used in connection with the Philippine problem in the Democratic platform of 1900. "We favor an immediate declaration," reads the platform of 1900, "of the nation's purpose to give the Philippines, first, a stable form of government; second, Independence; and third, protection from outside interference, such as has been given for nearly a century to the republics of Central and South America." Mr. Bryan, who was the author of the Philippine plank of 1900 , declared that the phrase "stable government" meant the same kind of government that was being established in Cuba. In accepting the nomination for the presidency, he said: "If elected, I will convene Congress in extraordinary session as soon as inaugurated and recommend an immediate declaration of the-nation's purpose, first, to establish a stable form of government in the Philippine Islands, just as we are now establish- 
ing a stable form of government in Cuba; second, to give independence to the Filipinos as we have promised to give independence to the $\mathrm{Cu}$ bans; third, to protect the Filipinos from outside interference while they work out their destiny, just as we have protected the republics of Central and South America, and are, by the Monroe Doctrine, pledged to protect Cuba." His opponent, President McKinley, did not differ from him as to the kind of government a "stable government" meant, but he did not favor at that time the establishment in the Philippines of such a government. He said: "We are required to set up a stable government in the interest of those who have assailed our sovereignty and fired upon our soldiers, and then maintain it at any cost or sacrifice against its enemies and against those having ambitious designs from without."

The Democratic platform of 1914 adrocated the same plan without using the phrase "stable government." It read: "We insist that we ought to do for the Filipinos what we have done already for the Cubans, and it is our duty to make that promise now and upon suitable guarantees of protection to citizens of our own and other countries resident there at the time of our withdrawal, set the Filipino people upon their 
feet, free and independent to work out their own destiny." The Democratic platforms of 1908 and 1912 contained the following: "We favor an immediate declaration of the nation's purpose to recognize the independence of the Philippine Islands as soon as a stable government can be established." As will be noticed, the preamble to the Jones Law was taken verbatim from the foregoing plank.

In the final settlement of the Philippine independence question, would the United States give any possible interpretation to the phrase "stable government" other than that which she had in the past, by a long line of precedents, given it? We doubt it. Nothing but a desire to evade the fulfillment of the promise would put a different interpretation to the pledge the American people have given to the Filipinos. A stable government cannot mean any other thing than what America has meant in Cuba. That is the only kind of government that can be termed "stable"- one that is supported and upheld by the people themselves through their peaceful suffrages. No other criterion for the stability of a human institution can be had than the fact that it rests upon the will of the people expressed through legal channels. 
That the Philippines now possess such a kind of government - a government elected by the people, capable of keeping order and fulfilling international obligations - is the firm conviction of the Filipino people as expressed by their constitutional representatives. That is why they deem it absolutely essential that the final settlement of the independence question be now made once for all. On November 7, 1918, the Philippine Legislature passed a concurrent resolution creating a "Commission of Independence" to be composed of the presiding officers of both houses of the Legislature and other mem. bers of the Legislature, for the purpose of considering and reporting to the Legislature:

"(a) Ways and means of negotiation now for the granting and recognition of the independence of the Philippines ;

"(b) External guarantees of the stability and permanence of said independence as well as of territorial integrity ; and

"(c) Ways and means of organizing in a speedy, effectual and orderly manner a constitutional and democratic internal government."

On March 7, 1919, the Philippine Legislature passed a Declaration of Purposes officially setting forth the position of the Filipino people on 
this vital problem. "The Philippine question," said the representatives of the Filipino people, " has reached such a stage that a full and final exchange of views between the United States of America and the Philippine Islands has become necessary. We need not repeat the declarations respecting the national aspirations of the Filipino people. Such declarations have been made from time to time in the most frank and solemn manner by the constitutional representatives of the Philippine Nation and are a matter of permanent record in public documents covering more than a decade of persistent efforts particularly during the last three years. America, on her part, has been sufficiently explicit in her purposes from the beginning of her occupation of the Philippines. . . .

"In applying the principles enunciated in documents and utterances on the Philippines to the conditions now existing in the Islands, the Independence Commission will find the following facts :

"That there exist at present in the Philippine Islands the conditions of order and government which America has for nearly a century and a half required in all cases in which she has recognized the independence of a country or the estab- 
lishment of a new government, not even excepting the case of General Huerta's government in Mexico which she refused to recognize because it was stained with blood and founded on intrigue, violence and crime;

"That there exist likewise in the Philippines all the conditions of stability and guaranties for law and order that Cuba had to establish to the satisfaction of America in order to obtain her independence, or to preserve it, during the military occupation of 1898-1903 and during the intervention of 1906-1909, respectively;

"That the 'preparation for independence' and the 'stable government' required by President Wilson and the Congress of the United States, respectively, contain no new requisite not included in any of the cases above cited;

"That these prerequisites for Philippine independence are the same as those virtually or expressly established by the Republican administrations that preceded President Wilson's administration;

"Therefore, so far as it is humanly possible to judge and say, we can see only one aim for the Independence Commission: Independence; and we can give only one instruction: to get it. Thus America, in adding another glory to her 
banner by establishing the first really democratic republic in the East will apply a second time, generously and freely, the same measure of humanity and justice that she applied in the case of Cuba." 1

One of the first actions of the Commission of Independence was to recommend the sending of a special Philippine Mission to the United States. This recommendation was approved by the Philippine Legislature in Joint Resolution No. 11, and forty prominent Filipinos representing both houses of the Legislature, commercial, industrial, agricultural and labor interests, presided over by Senate President Manuel L. Quezon as Chairman, and Secretary of the Interior Rafael Palma as Vice-Chairman. The Philippine Mission was officially received by Secretary of War Baker on April 4, $1919 . \quad$ Senator Quezon, Chairman of the Mission, presented the claim of the Filipinos, saying:

"The Philippine Mission, Mr. Secretary, is here charged with a high and solemn obligation. It is enjoined with a noble and sacred trust. It is instructed to present the great cause so essential and necessary to the happiness and ex-

1 For the full text of the Declaration of Purposes see Appendix $B$. 
istence of the entire Filipino people. I refer to our national birthright to be free and independent. We, therefore, formally submit hereby the vital and urgent question of Philippine Independence to you, and through you, to the Government of the United States, in the confident hope that it shall merit a just, righteous, and final settlement.

"Independence is the great national ideal of the Filipino people. The members of the Philippine Mission here, representing all elements of Philippine life, are, one and all, ready to testify to the absolute truth of this assertion. We believe that this is the proper time to present the question, looking to a favorable and decisive action, because of the declared and uniform policy of America to withdraw her sovereignty over the Philippine Islands and to recognize our independence as soon as a stable government can be established." 1

The representatives of the Filipino people have every reason to believe that there is now a stable Philippine government. Our present government, to quote Mr. Root's admonition to the Cuban people, is " a government based upon the

1 For instructions of the Commission of Independence to the Philippine Mission to the United States see Appendix C. 
peaceful suffrage of the people, representing the entire people and holding their power from the people, and subject to the limitations and safeguards which the experience of a constitutional government has shown to be necessary to the preservation of individual rights."

Our central, provincial and municipal governments rest upon the peaceful suffrages of the Filipino people. For more than a decade we have been successfully conducting through popular suffrage our provincial and municipal governments. "Native Filipino officials," says Governor-General Harrison, "are today governing one thousand municipalities and forty-two provinces, economically, efficiently, and for the good of the entire people." Our central government, as we have noted elsewhere, contains a complete governmental machinery, recognized and supported by the people. The active and governing part of that machinery is already in the hands of the Filipinos. We have an elective legislature, composed of the House of Representatives and a Senate, chosen by the qualified voters of the Islands. It has general legislative powers within the limitations of the Jones Law. In that legislature the non-Christian people are also represented by nine appointed members. In June 
of this year (1919) there will be a new election of the legislature, and the Filipino people will again be called upon to choose their national representatives.

We have a Council of State selected from the representatives of the people, which advises the Governor-General on all public matters, prepares the budget, determines the policy of the different departments of the government, and recommends measures to the legislature. While the Governor presides over the Council, the next highest position is the Vice-President of the Council, occupied by a Filipino.

We have a judicial system based on the sound American principle of an independent judiciary. Our laws and our courts are more modern and up-to-date than any in the Far East. Our codes are based on Spanish and American laws, taking in the conciseness, symmetry, and philosophic beauty of Spanish substantive law, together with the justice, practicability, efficiency of American procedure. Our judges, with a few exceptions, are all Filipinos, and they have proved that they can administer justice fairly and efficiently to nationals and foreigners alike. In this respect the Philippines are already more autonomous than independent China, for Chinese native 
judges cannot try foreigners. These are tried in extra-territorial courts by foreign magistrates.

Our present government is " subject to the limitations and safeguards which the experience of a constitutional government has shown to be necessary to the preservation of individual rights." The Philippine Government has been subject to such limitations and safeguards since 1900 when President McKinley in his instructions to the second Philippine Commission set down as inviolable rules the fundamental provisions of the American Bill of Rights. Those provisions with little modification were later included in the Organic Act of 1902, and again restated in the Jones Law of 1916. For nearly twenty years, therefore, the Philippine Government has been subject to constitutional limitations and safeguards. They are imbedded in the political life of the people, and no matter what political change may occur in the Philippines they will hardly find any material alteration.

Thus we see that not only can a stable government be now established in the Philippines: such a government Is ALREADY established there. In the words of Secretary of War Baker, who has departmental supervision of the Philippines, "the functions of government have been 
taken over by the people of the Islands themselves, leaving only the tenuous connection of the Governor-General." The Governor-General may leave tomorrow, and no institutional change will be necessary to continue the work of government. There is a stable government machinery set up and supported by the entire people and representing the entire people to which the governmental powers can be transferred. Under such a contingency the Vice-President of the Council of State, who has been raised to that position by the representatives of the people, will naturally assume the place of the Chief Executive, and the government could go on as before until the Filipino people should see fit to hold a constitutional convention for the drafting of a new constitution and the establishment of a new government.

But we have not only established a stable government which satisfies all - or more than all the conditions required by the United States. The very minute such a government was established in Cuba, the United States withdrew and turned over all the governmental powers to the newly established government. They did not wait to see how that stable government would work. It was sufficient for them that 


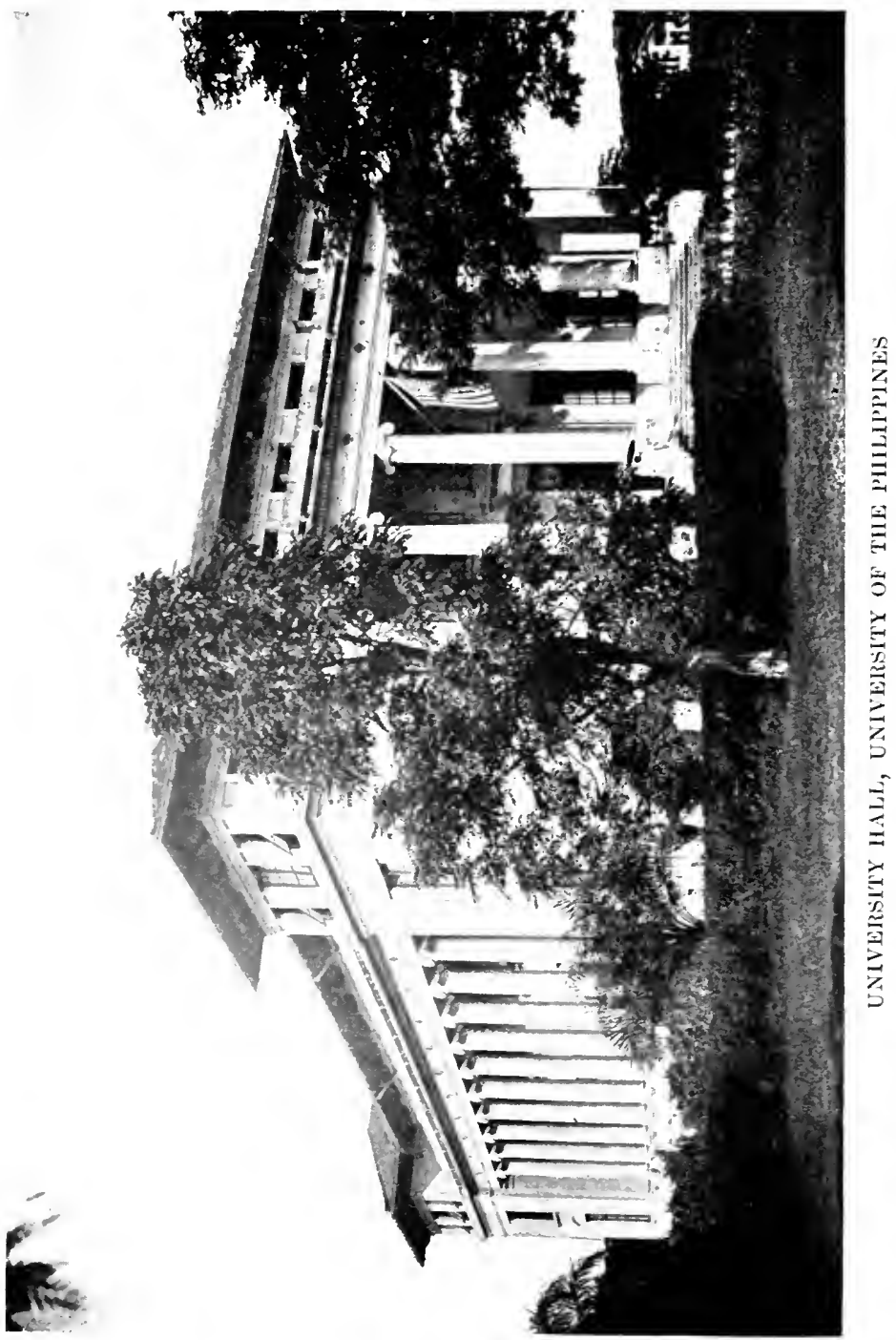




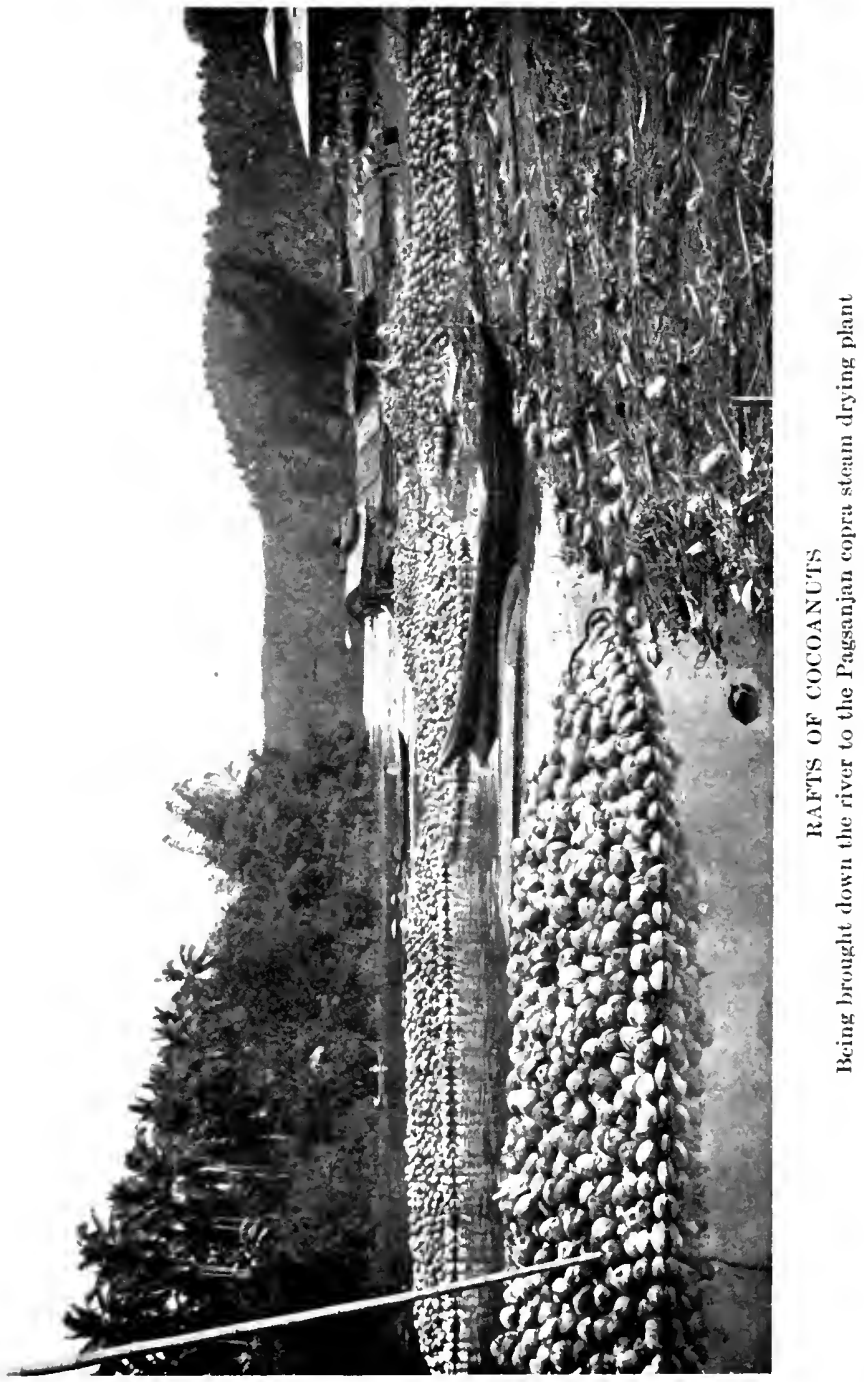


such a government - a government elected by the people - existed. Once convinced of that fact, they did not feel themselves justified in remaining a minute longer. We have not only established a stable government supported by the people, but we have successfully worked that government to the satisfaction of America's own representatives in the Islands. We have taken some pains to show in the previous chapters what this stable government has done for the country and the people. Let us hear what the American representatives in the Islands themselves have to say.

"The Filipino people," said Governor-General Harrison, "have come out triumphantly through their trial. By temperament, by experience, by financial ability, in every way, the ten millions of Filipinos are entitled to be free from every government except of their own choice. They are intelligent enough to decide for themselves. I have found the native Filipino official to be honest, efficient and as capable of administering executive positions as any men I have met anywhere in the world. These officials are today governing one thousand municipalities and forty-two provinces, economically, efficiently, and for the good of the entire people. 
"The wisdom and prudence of their representatives, the high degree of self-control which they possess, their true conception and faithful performance of their public duties have facilitated the immense task of the United States to establish here a stable and progressive government.

"The Philippines are away ahead of the United States in successful government ownership and operation of public utilities. The government took hold of the steam railways and made them pay a profit of $1,000,000$ pesos a year more than under private ownership. It took hold of the highways and we have 7,000 miles of the best macadamized roads in the world. The Manila city government is about to take over the street railways and the gas and electric plants, while the territorial government is arranging for ownership and control of the coal supply."

Vice-Governor Charles E. Yeater, now (1919) Acting Governor-General, is equally eloquent in his praise of the Filipinos. In an official cablegram he sent to the Secretary of War he said:

"The capacity for initiative and the constructive spirit evidenced by the legislature, the first organized under the Jones law, is worthy of great commendation. Its capacity to investigate 
government problems and to act expeditiously, but with due caution, is certainly unprecedented in history, considering that for three centuries this people had practically no political rights and were debarred from the benefits of education. American legislative practice and procedure has always been exnminor?. and, with few exceptions, followed. As indicative, however, of their independent frame of mind, it may be noted that a single legislative committee has had charge of both appropriations and ways and means since 1907 , and under the provisions of the Jones Law has adopted substantially the basic principles of the English budget system, instead of main. taining a rigorous application of the theory of the separation of governmental powers as far as the legislative and executive departments are concerned, the latter directed by an American. This legislature has given to the secretaries of the various departments the right to appear before either house to defend publicly the measures proposed by the executive, or to oppose measures originated in such houses.

"Finally, as one of the representatives in these Islands of the United States, I wish to attest the patriotism of the Filipinos and their loyal attachment to the United States Government. 
This legislature, which has just terminated its sessions, has acted with judgment and prudence, and in what it has done and left undone during its term now drawing to a close, should be credited for the wisdom with which it has guided and directed the Filipino people in the paths of order and tranquillity during these recent years of almost universal turmoil and unrest. Perfect peace has prevailed here, and all provincial and municipal governments' instrumentalities of force have had no function to perform."

President Wilson, in replying through the Secretary of War to the Philippine Mission, expressed his deep gratification "with the constant support and encouragement received from the Filipino people and from the Philippine Legislature in the trying period through which we are passing. The people of the United States," he said, "have, with reason, taken the deepest pride in the loyalty and support of the Filipino people. "Though unable to meet the commission, the Filipino people shall not be absent from my thoughts. Not the least important labor of the conference which now requires my attention is that of making the pathway of the weaker people of the world less perilous - a labor which 
should be, and doubtless is, of deep and abiding interest to the Filipino people.

"I am sorry that I cannot look into the faces of the gentlemen of this mission from the Philip. pine Islands and tell them all that I have in mind and heart as I think of the patient labor, with the end almost in sight, undertaken by the American and Filipino peoples for their permanent benefit."

Thus we have seen that American executive officials, including President Wilson, are already satisfied that the Filipino people have performed their part of the covenant with the American people. It now rests with the American people, through their constitutional representatives, the members of the American Congress, to consider whether the time has not already come to discharge their own obligations fully and completely. 


\section{CHAPTER IX}

\section{THE PROMISE OF THE PHILIPPINES}

"The Filipino people would not be just to themselves if, at this moment when their political separation from the sovereign country is proposed, they should fail to express in the clearest and most definite manner the sentiments and purposes that inspire their action. They therefore deem it their duty to affirm: That Independence, instead of destroying or weakening, will tend to strengthen the bonds of friendship and appreciation created by the gratitude of the Filipino people, not only for the final measure of complete justice and humanity that they confidently expect, but for all the previous disinterested work so splendidly performed for the benefit of the Philippines by so many faithful sons of America; that this gratitude will be the first fundamental fact in the future relations between the United States and the Philippine Islands; that in the present state of international affairs the Filipino people merely aspire to become another conscious and direct instrument for the progress of liberty and civilization; that in the tranquil course of their years of constitutional development they will maintain for all people inhabiting their hospitable land the essence and benefit of democratic institutions; that they will continue to associate, in so far as this 
will be acceptable and their strength will permit, in the work of reconstruction, justice, and peace carried on by the United States in continuation of those other undertakings, the high purpose of which was the cause, according to President Wilson, ' of the magnificent cooperation during the war '; and, finally, that in thus preserving their best traditions and institutions in the new situation which will strengthen and perfect them, the Filipino people will continue to make this country as heretofore a safe place of law and order, justice and liberty, where Americans and foreigners as well as Nationals may live peacefully in the pursuit of happiness and prosperity and safe in the enjoyment of their property as well as of their rights and their liberty." - Declaration of the Commission of Independence of the Philippine Legislature.

D ROPHETS of disaster have pictured a dark and gloomy future for the Philippines after the attainment of their independence. They see a weak, half-developed country in the midst of mysterious Asia, steeped in everlasting intrigues and deceit, and in their mental picture they behold the Islands immediately gobbled up or partitioned by selfish powers, or running headlong towards internal chaos and anarchy. As the Filipinos see it, the future of their country is not as dark as that. Even though we belong to a continent which has always been associated in the minds of Occidentals with mystery and in- 
trigue, we see a brighter prospect for our people. In the first place, we have no frontier problems, which are the most fertile source of international friction and difficulties and about which most of the wars in history have been waged. The knottiest problems before the Paris Peace Conference related to these very questions. Asia has suffered from the same malady. Siam, India and China have their frontiers constantly changed because of the oscillating interests that from time to time predominate on either side of their boundary lines. China had to yield Kowloon, because the security of Hongkong as an English possession demanded it. She may have to relinquish even her slight hold on Manchuria, which has been a bone of contention between her two northern neighbors. Japan's proximity to Korea facilitated annexation of that territory, because Korea in the hands of any other foreign power would be a menace to Japan. Similarly, the Liaotung Peninsula has twice changed foreign masters because of its propinquity to Russia and Japan. Siam has had to submit to changes in her frontiers many times and has suffered each time a considerable interference in her domestic affairs.

The Philippines are geographically more fortu- 
nately situated than other oriental countries. Our frontiers are determined by God Himself through the tremendous waterways that separate us from the mainland of Asia. Although the Archipelago is composed of thousands of islands, the possession of a single one of them is of little use unless it is accompanied by the possession of the whole group. America found this out at the Treaty of Paris of 1898. At first she wanted Luzon alone, but the closeness of the islands to one another made her decide to take over all or none. The problem of the international relations of the Philippines with the neighboring countries would also be simplified by the geographical position of the Islands. We hear of the so-called Japanese menace. In fact, danger from Japan is the most serious argument advanced against the independence of the Philippines. Japan is pictured as a land-hungry nation, awaiting only the withdrawal of American power from the Philippines for the opportunity to take over the Islands. If we examine the question calmly, we shall arrive at certain facts which will help us to consider the question on its own merit. In the first place, it is doubtful if Japan would find it to her advantage completely to colonize the Islands. The task of con- 
verting the ten million Christian Filipinos into unwilling Japanese subjects would be fraught with much greater difficulty than that encountered by Japan in the subjugation of other peoples. Dr. Nitobé, the foremost Japanese authority on colonial questions, has commented on the opposition of Filipinos to any attempt at Japanese rule. In an interview published in the Philippines Free Press on May 6, 1916, when on a tour of investigation, he said:

"It is rash to conclude that because we are of the same race the Filipinos would gladly invite Japan to be their ruler.

"They believe that they are superior to the Japanese. Their customs and manners are influenced by Christianity; hence the unequalled progress in the conception of their treatment of the weaker sex in comparison with that prevailing in other parts of the East. The Filipinos are no equals of the Japanese in the matter of politics, national defense, and industry, but possessing as they do such foreign ideas and customs, though ancient, they rather look down upon the Japanese. It remains a serious question, in these circumstances, if they will condescend to look up to the Japanese as their superiors.

"They have, furthermore, not neglected to pay 
close attention to the Japanese administration in Formosa and Korea. In the Philippines, the natives enjoy unlimited liberty of speech; they write and discuss as they like, and no official intervention takes place. Viewed from this respect alone, would the Filipino welcome Japanese control, when he realized the present conditions of Japan's policy in Formosa and Korea?"

"If Japan should ever attempt to take the Philippines, either peacefully or by force," says an opponent of independence, Carl Crow, in his book "America and the Philippines," " she would immediately be involved in a fight much more stubborn than the one the United States was compelled to put down. It is impossible to imagine the devoutly Catholic Filipinos ever submitting even to a semblance of rule by a nation as essentially non-Christian as the Japanese, and it is equally impossible to imagine a Christian world allowing such a reverse to the unbroken advance of Christianity."

"It took us three years of exasperating guerrilla warfare," says another American writer, James A. Abbott, " before opposition to our presence finally disappeared. And how did we succeed at last! By killing off as many of the pop- 
ulation as possible? Hardly; if that had been our policy, we should be doing it still. We only succeeded when we convinced the Filipinos that we were not there to exploit them."

No great national gain can accrue to Japan through the subjugation of the Philippines. The complete possession of the Islands would scarcely compensate Japan for the probable cost of such a procedure. It is still an open question whether the Japanese can successfully settle in the tropics. The exceptional opportunities of Davao are at present drawing Japanese to that place, but even there Japanese immigration is still in an experimental stage. It is entirely uncertain whether Japanese laborers can thrive in the other parts of the Islands. The Japanese colonization of Formosa, which lies in a colder belt than the Philippines, is still far from being a success. Japan has had the Island for over twenty years, and yet there are now barely 150,000 Japanese in it - this in spite of the fact that the Japanese Government gives financial help to Japanese subjects emigrating to Formosa. It is said that in 1912 alone the Japanese Government spent over $\$ 200,000$ to help 1,760 emigrants to the Island. ' Japan's natural place for expan-

1 Abbott, “Japanese Expansion,” p. 218. 
sion is Korea and Manchuria. In Korea alone there are over 200,000 Japanese, whereas ten vears ago there were probably less than 50,000. Korea has only a concentration of 173 persons per square mile (as against Japan's 342 per square mile), so that there is still room for many Japanese. But Manchuria is by far the promised land of Japan's surplus population. With an area of 376,800 square miles, rich in natural resources, and with barely a population of 10,000,000 , she can feed a population of from sixty to one hundred million people. Under the complete political control of Japan, Manchuria will undoubtedly afford untold opportunities for Japanese excess population.

Dr. Iyenaga, one of Japan's most active publicity agents in the United States, once said that Japan would not accept the Philippines even as a gift. "Unless that gift should be accompanied not by $\$ 20,000,000$, the sum you gave to Spain, but by a round billion of dollars to be expended for the education and development of the Filipinos, Japan would surely decline your offer. Japan has no use for the Philippines for colonization purposes because its climate is as unfitted to us for that purpose as it is for your. Our experience in Formosa has convinced us of 
that." 1 Another Japanese writer equally well known in the United States, Mr. K. Kawakami, while not going as far as Dr. Iyenaga, emphatically says that Japan has no desire to acquire the Philippines.

Many Japanese believe that with Korea, Manchuria and Formosa, Japan is sufficiently occupied with territorial dominions, and that in the long run it would be more advantageous for her to adopt a policy of righteousness and fair dealing with all nations than to seek new fields of conquest. An assurance to that effect would greatly strengthen her friendship with the Allies and, consequently, her own credit abroad. It is for this reason that Count Okuma, while Premier of Japan, sent the following interesting telegram to the United States on August 24, 1914: "As Premier of Japan, I have stated, and now again state to the people of America and the world, that Japan has no ulterior motive, no desire to secure more territory, no thought of depriving China or other people of anything they now possess."

Granting, then - at least for the sake of argument - that Japan will not endeavor to colonize the Philippines, what are the principles

1 Quoted in the Far Eastern Review, September, 1916, p. 128. 
upon which sound and friendly Filipino-Japanese relations can be built? Japan will surely find the Philippine Republic a friendly neighbor and sister. The Filipinos themselves have nothing but admiration and good wishes for an Asiatic people who, by their own strength, have won the recognition of a hitherto doubting world and have carved their proud name in the councilchamber of the great nations. The Philippines are asking only for an opportunity for free and unhampered development of their people and natural resources, so that they can, in their hum. ble way, contribute to the civilization and progress of mankind. This desire cannot be of any possible damage to Japan. On the contrary, what Japan desires of her neighbors is the least possible interference by western nations. She told that to China many times, and that was the main reason she gave for annexing Korea.

Is it not, therefore, clear that both the Japanese and Filipino nations can work in harmony toward the furtherance of their common interests?

The problem of government in the Philippines is relatively much simpler than that in any other tropical country of Asia. The Filipino people are already a unified mass, loyal to a centralized 
government. They have no institutions of royalty, nobility or blood distinctions, which make republican institutions for the time being impossible in Java, the Malay States and the protectorate of Indo-China. Even the strongest opponents of our independence concede us that advantage. "Contrast the Filipinos with other Malays and the Oriental peoples," says Mr. Taft, " and I ask you to name a people offering more opportunities for development along the lines which American ideals require than the people of these islands. To begin with, they are a Christian people and they have been so for three hundred years. They have no caste or arbitrary customs which prevent their development along the lines of Christian civilization. They differ utterly in these respects from the East Indians, from the Malays of Java and the Malays of the Straits Settlements, and thus make our problem different from and vastly easier than that of England and Holland."

No better material can be found in Asia for the development of a democratic state than the Philippines. The twenty years of American occupation have accomplished wonders in the development of this potential democracy into a practical representative government. Accord- 


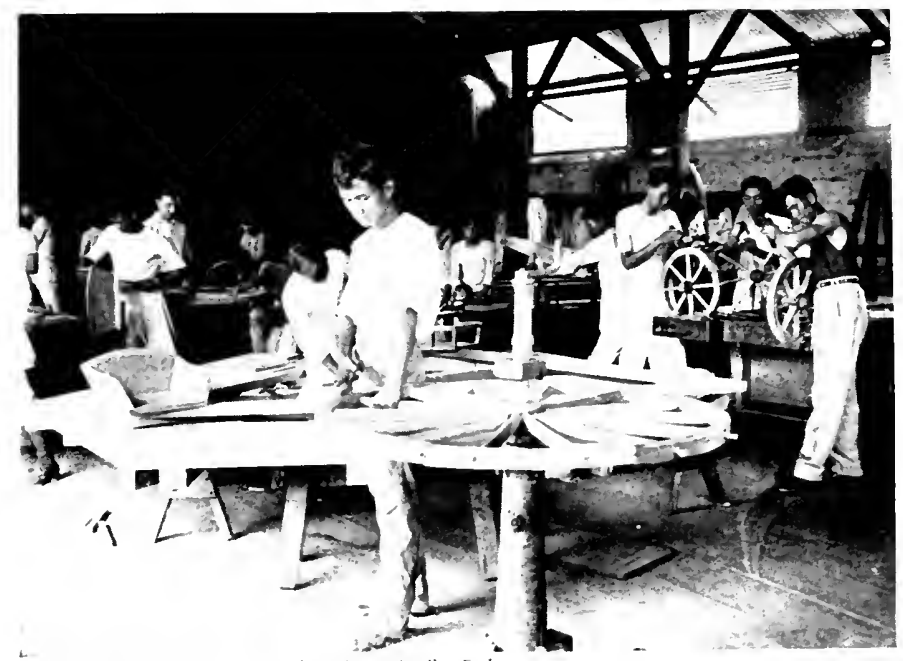

Photograph by furedu of kudcaciua, Manila, F. I.

A VIEW FROM UNE OF THE 16 PROVINCIAL TRADE SCHOOLS

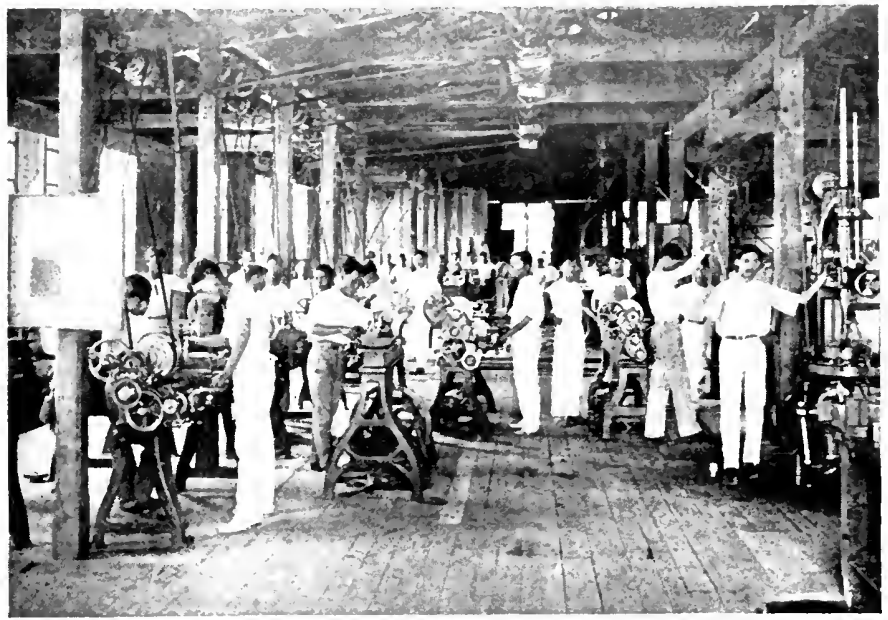

THE MACHINE SHOP, SCHOOL OF ARTS AND TRADES, MANILA The vocational training branch of the Philippine educational system is declared to be the most advanced in the world 


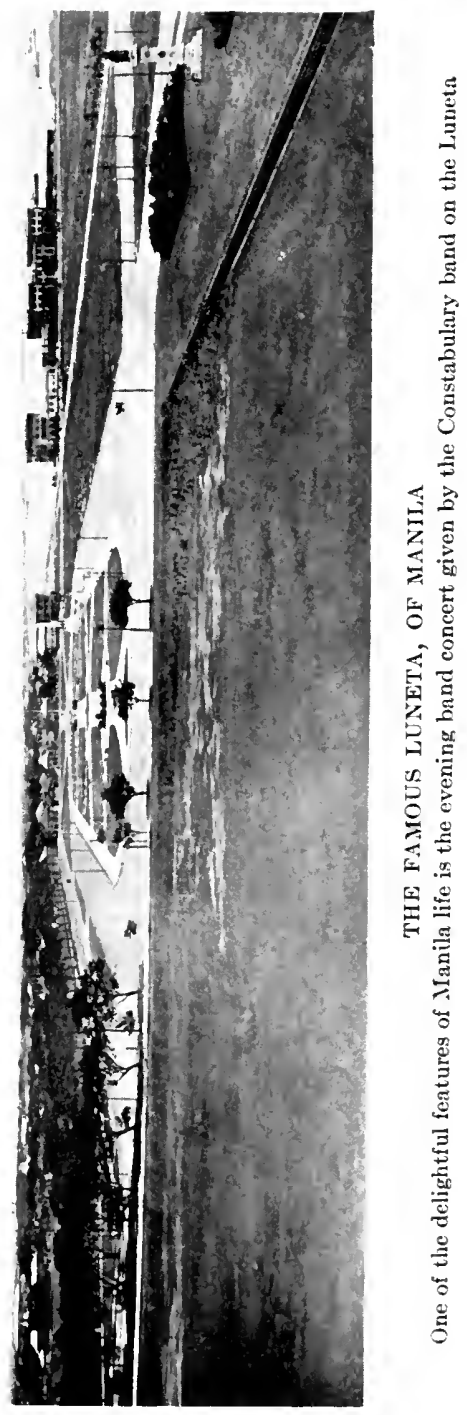


ing to the official census estimate of 1918 cabled to the War Department by Acting Governor Yeater, over seventy per cent of the population over ten years of age are literate. This is higher than in any country in South America, certainly above the literacy of the new states recognized in Europe and even far ahead of that of Greece, Portugal, Roumania and Serbia. Although suffrage is limited to male persons who are literates or who have property to the value of $\mathbf{5 0 0}$ pesos, there are already, according to the same census estimate, over $1,750,000$ voters in the Islands.

In spirit the Philippines are today the most democratic country of the Far East. It is for this reason that upon the outbreak of the European War, even before the entry of the United States, the Filipinos were already in spirit with the Allies, for they instinctively felt that democracy was on the side of the Allies, while autocracy was with the Central Powers. They do not, like the Japanese, offer blind obedience to a Mikado, a political attitude which, despite its recognized advantages, is an enduring obstacle to the establishment of democracy in Japan. "The Emperor of Japan," says a distinguished Japanese writer, G. E. Uyehara, "is the center of the 
State as well as the State itself. $\mathrm{He}$ is to the Japanese mind a Supreme Being in the Cosmos of Japan, as God is in the Universe to the pantheistic philosopher. From him everything emanates; in him everything subsists; there is nothing on the soil of Japan existent independent of him. He is the sole owner of the Empire, the author of law, justice, privilege, and honor, and the symbol of the unity of the Japanese nation." The same author confesses that "this mental habit of the people is a great obstacle to the healthy development of representative govern. ment. The masses of Japan still maintain a reverential attitude towards the government and look upon the government officials as superiors; they still cannot quite realize that the govern. ment is by the people."

Contrast the foregoing attitude with the political philosophy the Filipino leaders of the past have endeavored to instill in the minds of the people and the unstinted adherence of the people to the cause of democracy. Apolinario Mabini, the greatest political writer the Filipinos have produced, drove home to the people the following creed of democracy: "Thou shalt not recognize in the country the authority of any person who has not been elected by thee and by 
thy countrymen; for authority emanates from God, and as God speaks in the conscience of every man, the person designated and proclaimed by the conscience of a whole people is the only one who can use true authority." The national Constitution adopted by the Filipino representatives at Malolos solemnly declares that "sovereignty resides exclusirely in the people." Add to this the schooling in democracy the Filipino people have had for twenty years under American guidance, and we may realize the advantage the Philippines have over their Oriental sisters in the establishment and maintenance of democratic institutions.

The present government of the Philippines, in spite of its inherent faults, due to the fact that it was framed by an alien Congress, has certainly made it possible to bring to the fore men of undoubted popularity to direct the affairs of the nation. Although not elected at large, but simply by their districts, and later elevated to their posts by representative organs of the people, the three foremost leaders of the party in power - the Speaker, Sergio Osmeña, the President of the Senate, Manuel L. Quezon, and the Secretary of the Interior, Rafael Palma - are recognized by all Filipinos as the ablest men in 
the party. One of the requisites, the most fundamental one, of a true democracy is therefore fulfilled in the Philippines: that the leaders of the party in power who enjoy the greatest popular support are given the direction of governmental affairs.

But there is another fundamental reason why democracy has a splendid chance of developing in the Philippines. According to the official census estimate of 1918 , there are a million and a half farms in the Islands, and ninety-six per cent of these farms are owned by Filipinos. In other words, out of the ten million Christian Filipinos, eight million of them at least live on their own farms, with houses of their own, independent of any absentee landlord or foreign master. Ninety-one per cent of the urban property consisting of houses and lands is owned by the natives of the Philippines, and only nine per cent is in the hands of foreigners. A people with property so evenly divided, with practically everybody owning a piece of land which he is willing to defend with his own life against lawless intruders, has certainly a chance to maintain stable political institutions.

A survey of the promise of the Philippines would not be complete without saying something 
of the Filipino woman. The position of the Filipino woman in the Orient is unique. "Midway geographically between the kimono maiden of Japan and the veiled lady of India," says an American writer," "and alongside of the "lilyfooted' dame of China is the woman of the Philippines, a woman unique in the Orient, a woman in whose development there has been neither seclusion, nor oppression, nor servitude." Even before the coming of the Spaniards four centuries ago, the Filipino woman held a relatively high position. The Spanish discoverers found the Filipino woman sharing equally with her husband the rights and duties of the home, and in case of his death inheriting half of their joint gains. Sometimes the position of the chief official of a town, upon his death, fell to the widow when there was no male heir. Christian ideals strengthened the position of the Filipino woman and gave her even greater freedom and power. Today she is the mistress of the home and the safe keeper of the family funds. Through her hold in the home she wields a strong influence in the outside world. In business she is the equal, if not the superior, of her mate; and politically, though she does not enjoy popular

1 Emma Sarepta Yule, in the Philippines Monthly, 1915. 
suffrage, she has proved, to quote the American writer again, " in more than one case, indeed in very many, that she is an active campaigner of no mean order."

The education of the Filipino woman has broadened her scope in life and is making her more interested in the civic activities of the Philippines. In 1917 there were enrolled in the primary and intermediate grades of the public schools 234,905 girls. Filipino women are now occupying positions in the Bureau of Education and the University of the Philippines. While there is no strong agitation for suffrage, it is doubtful whether, whon they demand it, their brothers will deny it to them. There have been established over fifty women's clubs in the Philippines, engaged in social settlement work, the improvement of health conditions, and the prevention of infant mortality. Writers on the Philippines and observers of Philippine conditions have time and again testified to the superiority of women in the Philippines, and to the tremendous influence that they are bearing, and will continue to bear, upon the country and the people. "Possibly . . . on these lovely isles where the lotos blooms and the cocoanut lifts high its green-crowned head there may evolve 
the Altruria of the vision of the suffragette, a land of perfect sex equality with chivalry tipping the scale in favor of lovely woman." That was the promise pictured by the American writer who has paid such a pleasing tribute to the Filipino women.

The agricultural and commercial possibilities of the Islands are almost limitless. Of the total area of 120,000 square miles of rich tropical land only 14,000 square miles have been touched by the plow. The 100,000 square miles remain in its primeval state just awaiting the industry of man to give up its mineral wealth or to produce bountiful crops of sugar, hemp, cocoanuts, rubber, and all sorts of tropical raw materials. The Philippines can hold from sixty to seventy million people. The valley of Cotabato alone can produce enough rice to feed the present population of the Islands. The entire Archipelago, through scientific cultivation, the development of its natural resources, the harnessing of its wonderful water powers and the development of its commerce, can be converted into a veritable paradise. That the Philippines have every natural advantage for economic independence is amply substantiated.

Is it any wonder, therefore, that the Filipino 
people should have such a splendid optimism as regards their country's future? They are convinced that in a modest way they have a manifest destiny to fulfil. This destiny cannot be realized unless they are independent of all foreign control, free to develop their country and their genius in their own way. It must be confessed that the domestic autonomy which they now enjoy fails to satisfy them completely. It is simply a privilege conceded them, the United States still continuing to be the absolute arbiter of their destiny. The Filipino people have no voice in their foreign affairs, and thus they have to limit their activities to purely local matters and cannot participate in those world enterprises which are, in these days of international intercourse and communication, the greatest factors in the growth and progress of nations. Even in the final disposition and development of their natural resources, such as timber, mining concessions, and public lands, as well as in other important matters, they must first obtain sanction of the President of the United States. The American flag still symbolizes to them the sovereignty of a foreign people, no matter how lightly or generously exercised that sovereignty may be. The United States Congress can take 
away any rights or privileges that have been granted to them. Their Bill of Rights can be taken away at any moment. The Supreme Court has held that the Filipino people enjoy only such civil and political rights as the American Congress is willing to give them.

The preamble to the Jones Law simply promised the Philippines their independence as soon as a stable government could be established therein. It did not specify the relationship that would exist between an independent Philippines and the United States, evidently leaving that matter for future negotiations. It is for this purpose of negotiating the final terms of independence that the Philippine Congress appointed a permanent Commission of Independence, which sent a special Philippine Mission to the United States. The terms and conditions of Philippine independence and the future relationship between the two countries should now be taken up by their respective representatives. Evasion of the subject or unnecessary delay may be highly detrimental to both parties. It has been the policy of evasion, the lack of definite understanding, which caused the past difficulties between the two peoples.

The Filipino people are too grateful for the 
benefits received from the United States not to concede to the American nation whatever privileges or conditions she may impose, consistent with their welfare. "This gratitude," says the Philippine Congress, "will be the first fundamental fact in the future relations between the United States and the Philippine Islands." A final understanding with the American people is imperative, if for no other reason than to acquaint the Filipino people with the responsibilities they must face after their separation from the United States. The Jones Law provided only for the organization of the internal government as a prerequisite to the granting of independence. Our internal government is already organized on a stable basis. The next and logical step is the negotiation for independence.

The ten million Filipinos are not such a very small people. Their desire for freedom is no mere passing whim. It was written in blood during those dark days of 1896-1898, when they overthrew the tyrannous yoke of Spain. It was rebaptized in those gloomy years of 1899-1902 when, although convinced that they would be defeated in the end, they gave up thousands of lives to show the American people that they 
would not lightly exchange political masters and that they were willing to die if need be for the independence of their country. Secluded as they are from Asia, protected by tremendous waterways, with no frontier problems or large vested foreign interests, save those of the United States, to vex them, united by a strong tie of nationality, inspired by democratic ideals, with untold economic possibilities at their command, they feel that they have a good chance to work out their own destiny. Weaker and smaller nations, beset by graver problems, have taken a more hazardous chance at freedom.

In the opinion of many observers, the Filipino people have progressed much more remarkably than the Japanese in a similar space of time. This progress has been made, inspired by the promises of the United States that they would in due time enjoy the blessings of complete freedom. Nations, like individuals, accomplish more when they encounter difficulties and look ahead to a sublime ideal for their guide. Under a flag of their own, as a member of the concert of free nations, confronted by greater problems and even much greater difficulties - who can foretell what further strides the Filipino people may not make and what greater surprises 
they may not give the expectant world? Sixty years ago Commodore Perry opened to the world an Oriental country ignorant of the ways of civilization, living in a mist of medievalism, and in that brief space of time they have forged ahead, put on the garb of the Occident, bridged the chasm of centuries which separated them from the modern world and secured for themselves a place among the great powers of the earth. The Philippines, though a smaller country, have been under the influence of Christianity for three hundred years and have had the tutorship of the greatest and most enlightened republic for twenty years. Who can foretell the fate that the Supreme Arbiter of the destiny of nations has reserved for them? 


\section{APPENDIX A}

\section{THE PREAMBLE TO THE JONES LAW}

\section{(Approved August 29, 1916.)}

An Act to declare the purpose of the people of the United States as to the future political status of the people of the Philippine Islands, and to provide a more autonomous government for those islands.

WHEREAS, it was never the intention of the people of the United States in the incipiency of the War with Spain to make it a war of conquest or for territorial aggrandizement; and

WhEREAS, it is, as it has always been, the purpose of the people of the United States to withdraw their sovereignty over the Philippine Islands and to recognize their independence as soon as a stable government can be established therein; and

WHEREAS, for the speedy accomplishment of such purpose it is desirable to place in the hands of the people of the Philippines as large a control of their domestic affairs as can be given them without, in the meantime, impairing the exercise of the rights of sovereignty by the people of the United States, in order that, by the use and exercise of popular franchise and governmental powers, they may be the better prepared to fully assume the responsibilities and enjoy all the privileges of complete independence: Therefore ... 



\section{APPENDIX B}

RESOLUTION OF THE SENATE AND HOUSE OF REPRESENTATIVES OF THE PHILIPPINES, IN JOINT SESSION ASSEMBLED, ADOPTING A DECLARATION OF PURPOSES FOR THE GUIDANCE OF THE COMMISSION OF INDEPENDENCE

Whereas the Commission of Independence has informed the Philippine Legislature that it is ready to receive from it instructions or declarations for its future guidance, in order to insure the best possible performance of the duties of the Commission: Now THEREFORE,

Be It Resolved by the Senate and House of Representatives of the Philippines, in joint session assembled. in the Marble Hall of the Ayuntamiento, that the following Declaration of Purposes be, and the same hereby is, adopted, to wit:

Declaration of Purposes: The Philippine question has reached such a stage that a full and final exchange of views between the United States of America and the Philippine Islands has become necessary. We need not repeat the declarations respecting the national aspirations of the Filipino people. Such declarations have been made from time to time in the most frank and solemn manner by the constitutional representatives of the Philippine nation and are a matter 
of permanent record in public documents covering more than a decade of persistent efforts particularly during the last three years. America, on her part, has been sufficiently explicit in her purposes from the beginning of her occupation of the Philippines. It is true that the Treaty of Paris whereby the sovereignty formerly exercised by Spain passed to the United States, was negotiated and concluded without intervention or consent of the Filipinos, and that the United States of America did not occupy the Philippine Archipelago upon a previous categorical declaration like that formulated and made public before the occupation of Cuba. But, aside from certain differences in the details of both occupations which, not having been foreseen upon the Declaration of War between the United States and Spain, subsequently gave rise to debate and differences of opinion regarding procedure, it is an incontrovertible fact that the definite purpose of the United States in both cases was the same: the disinterested liberation of the people subjugated by Spain. The American flag that waved over Cuba for lofty reasons of humanity and justice scrupulously observed and respected after the victory, is the same flag which, when the war spread to this part of the globe, extended its protecting folds over another people anxious for justice and liberty. And that American flag could not stand for emancipation in Cuba, and, at the same time, for forcible subjugation in the Philippines. The difference, if such ever existed, consisted only in matters of detail, not in the affirmation and observance of the cardinal prin- 
ciples. In one case, owing to the proximity of Cuba to the American shores, the terms of the problem were known at the outset and provisions had been made for its solution. In the other, the lack of adequate information in the United States as to the true conditions of the Philippine problem, aggravated by long distance, momentarily obscured the question and naturally gave rise to a less determined and speedy procedure. Thus, while Cuba became free and independent after scarcely four years of American occupation, the Philippines, which professed the same ideals as their sister of the Antilles, continue in a state of dependency after more than twenty years of such occupation.

In submitting the Philippine question to the Government and People of the United States, the Commission of Independence will find it unnecessary to refer to the natural acerbity of the situation, or to the anxiety of our people which two decades of occupation have only served to accentuate. The steadfastness of our position is not due to mere sentiment, but to the justice of our cause, sanctified by the laws of God and Nature not only, but admitted in the promises solemnly made by the United States and accepted by the Philippines. Although attention should respectfully be invited to the fact that the Filipino people have never renounced their independence, not even in the moments of the greatest adversity brought about by the enforced or voluntary submission of their own leaders, yet the Commission of Independence in dwelling upon the promises made, will unreservedly and with 
the deepest gratitude recognize that they were made freely and generously to a small and powerless people after they had suffered defeat in the field of battle. The deliberate attitude of our country in reposing confidence in those promises and laboring peacefully in pursuance thereof, must also be asserted. Thus, after the rupture of relations occasioned by three years of war during which the right of the Filipinos to their independence was disputed, unsuccessfully so far as they were concerned, violence gave way to harmony, and hostility to cooperation; and thanks to the growing influence of the new conditions of peace, Americans and Filipinos, who a short time ago fought each other and stained the Philippine soil with blood, undertook jointly, on the basis of a friendly understanding, a magnificent labor which has been carried on with the orderly progress of liberty and selfgovernment.

The Commission must not lose sight of the fact that the altruistic ideals and the wise and efficient aid of America in peace justly won for her our confidence and gratitude. Far from allowing a policy of selfish exploitation to direct the destinies of these Islands, America proclaimed and insisted that the interest and welfare of the Philippines were to be considered a sacred trust confided to the people of the United States. Instead of the national spirit being stifled, it was announced from the outset that the natural development of self-government would be promoted. The total surrender of the government of the municipalities to popular control, the constant increase in the 
measure of self-government in the administration of the provinces, and the growing participation of the people in the management of the central government and of national affairs; the plan of a general free elementary education conceived from the start; the establishment of the national assembly, with the subsequent addition of an elective Senate, and, finally, the acceptance of the offers of adhesion and aid of the Philippines to the cause of America in the recent war, based on the principles of justice and self-government, liberty and security for small nations, as proclaimed by the Government of the United States, are fundamental facts of the policy of America in these Islands which have appealed to the heart and brightened the hopes of the Filipino people. President Roosevelt, proudly contemplating, rather than the initial results of the work, the loftiness and purity of the principles enunciated, said with good reason that "no great civilized power has ever handled with such wisdom and disinterestedness the affairs of a people committed by the accident of war to its hands." " Save only our attitude towards Cuba," Mr. Roosevelt continued, "I question whether there is a brighter page in the annals of international dealing between the strong and the weak than the page which tells of our doings in the Philippines "'(January 27, 1908), and subsequently he proclaimed, in a message to Congress, that " the Filipino people, through their officials, are therefore making real steps in the direction of self-government " and that he hoped and trusted that these steps would mark "the beginning of a course 
which will continue till the Filipinos become fit to decide for themselves whether they desire to be an independent nation." (December 8, 1908.) In the opinion of William H. Taft, who implanted our civil régime, the national policy with regard to the Philippines contemplated a gradual and constant extension of popular control, and, making a logical deduction, he said " when the Filipino people, as a whole, show themselves reasonably fit to conduct a popular selfgovernment, maintaining law and order and offering equal protection of the laws and civil rights to rich and poor, and desire complete independence of the United States, they shall be given it." (January 23, 1908.) These statements of Mr. Taft, made while he was Secretary of War, were confirmed by him when, as President of the United States, he said in a message to Congress: "We should endeavor to secure for the Filipinos economic independence and to. fit them for complete self-government, with the power to decide eventually, according to their own largest good, whether such self-government shall be accompanied by independence." (December 6, 1912.)

On March 4, 1913, there was a change in the administration of the United States and the power passed from the Republicans to the Democrats. Seven months later, Francis Burton Harrison, the new Governor General, communicated to the Filipino people the following message from President Wilson: "We regard ourselves as trustees acting not for the advantage of the United States, but for the benefit of the people of the Philippine Islands. Every step we take 
will be taken with a view to the ultimate independence of the islands and as a preparation for that independence. And we hope to move toward that end as rapidly as the safety and the permanent interests of the islands will permit. After each step taken, experience will guide us to the next" (October 6, 1913). On the occasion of the change in the Philippine Commission, which acted as the upper house of the legislature, the Filipinos were given an effective majority in both houses, and in accordance with the new policy that in the administration of affairs in the Philippines America desired not her own counsel, but the counsel of the Filipinos, the Filipinization of the service was accelerated and other administrative measures were adopted to extend the popular control in the government. Finally, maintaining all the progress made and emphasizing the steps toward independence, frankly announced by President Wilson, the Congress of the United States approved the new organic law for the Philippines of August 29, 1916, which formally promises the Filipinos their independence and grants them a more autonomous government. Thus the burden of the international responsibilities assumed by the United States by virtue of the Treaty of Paris passed in effect to the hands of the Filipino people, and a pact was virtually consummated between America and the Philippines, analogous to that established between America and Cuba by the passage of the Teller resolution which led to the war between America and Spain and publicly defined America's purpose at that time. 
During this period of confident waiting, when our attitude was one of mere cooperation as well as when we assumed the new powers conferred by the Jones Law, the Commission of Independence will find, throughout the entire record of over twenty years, positive facts demonstrating our full capacity for national independence and self-government. In the plan of a general free education and of sanitary improvements; in the vast public works program with respect to roads and bridges, public buildings, and irrigation systems; in the fostering of agriculture, industry, and commerce, including the provision of banking facilities, port improvements, and an adequate system of transportation by land and sea; in the establishment of an efficient civil service and an independent judiciary; in the constant development of self-government in the local organizations and the central government, and in the adoption of measures for the free and orderly exercise of popular suffrage; in the exercise, in fine, of all the political powers entrusted to us, no effort has been spared to promote the public good. Any unprejudiced critic will find after an impartial examination, that we have successfully created a condition which demonstrates that the Filipino people, in managing their own affairs, can maintain law and order, and afford equal protection to all, whether foreigners or nationals.

Despite the party struggles that precede the elections, particularly those that attended the first general election held on the occasion of the inauguration of the Philippine Assembly, the work of that body 
and that of the present purely elective legislature which succeeded it, show that there exists in these islands a strong and complete national unity which places general inerests above petty local partisanships. In our budget system successfully implanted since both Houses became elective, no costly extravagance, local selfishness or "log-rolling " and " pork barrel" practices find any place. Our financial system and the appearance of cabinet members before the Houses of the Legislature have effected a coordination of forces and leadership which has promoted the efficiency of the administration and assured its responsibility to the people. The stability of the present government, managed almost entirely by Filipinos, has been put to a test not only by the extension of its authority to all the remote districts of the islands inhabited by Mohammedans and other non-Christian Filipinos, where, as in the rest of the country, there now reigns perfect order maintained by civil officers, but also by the uninterrupted maintenance of a complete state of peace, order and security during the recent war which devastated the fields of Europe and sowed the seed of restlessness and discontent throughout the world.

As an evidence of the appreciation of the high purposes and disinterested work of the Americans who have aided the Filipinos, all useful public institutions in existence at the inauguration of the Philippine Assembly in 1907 have been preserved and perfected. Notwithstanding the policy of Filipinization implanted by President McKinley, no American em- 
ployee in sympathy with this country and with the common work carried on has been retired from the service against his will and without an equitable compensation. It must be a source of legitimate pride and satisfaction to every American to know that the noble and humanitarian purposes expressed by President McKinley and his successors in their instructions, messages, and other official documents as the reason for American occupation have been successfully attained by the united and harmonious effort of Americans and Filipinos.

Now, in applying the principles enunciated in documents and utterances on the Philippines to the conditions now existing in the Islands, the Commission of Independence will find the following facts:

That there exist at present in the Philippine Islands the conditions of order and government which America has for nearly a century and a half required in all cases in which she has recognized the independence of a country or the establishment of a new government, not even excepting the case of General Huerta's government in Mexico, which she refused to recognize because it was stained with blood and founded on intrigue, violence and crime.

That there exist likewise in the Philippines all the conditions of stability and guaranties for law and order that Cuba had to establish to the satisfaction of America in order to obtain her independence, or to preserve it, during the military occupation of 18981902 and during the intervention of 1906-1909, respectively ; 
That the "preparation for independence" and the " stable government" required by President Wilson and the Congress of the United States, respectively, contain no new requisites not included in any of the cases above cited;

That these prerequisites for Philippine independence are the same as those virtually or expressly established by the Republican administrations that preceded President Wilson's administration;

That during the entire time that the Filipino people have been with America, they have been living in the confidence that the American occupation was only temporary and that its final aim was not aggrandizement or conquest, but the peace, welfare, and liberty of the Filipino people;

That this faith in the promises of America was a cardinal factor not only in the cooperation between Americans and Filipinos during the years of peace, but also in the cooperation between Americans and Filipinos during the late war;

That the condition of thorough development of the internal affairs of the country and the present international atmosphere of justice, liberty, and security for all peoples are the most propitious for the fulfillment by America of her promises and for her redemption of the pledges she has made before the world.

In the light of these facts and considerations, the Filipino people are confident that it will be possible to arrive at a satisfactory final decision, as we deal no longer with a disputed question, but are merely endeavoring to agree upon the final adjustment of a 
matter with regard to which, according to President Wilson's words, there exists, so far as fundamentals are concerned, " a perfect harmony of ideals and feelings " between the governments of the United States and the Philippine Islands, which harmony has brought about " that real friendship and mutual support which is the foundation of all sound political policy "' (November 29, 1918).

Therefore, so far as it is humanly possible to judge and say, we can see only one aim for the Commission of Independence : independence; and we can give only one instruction: to get it. Thus America, in adding another glory to her banner by establishing the first really democratic republic in the East will apply a second time, generously and freely, the same measure of humanity and justice that she applied in the case of Cuba, which is but a logical and natural sequence of the immortal principles of the Declaration of Independence. This Declaration, which belongs to all humanity, has now as much force as it had in the days when America proclaimed it. America will thus vindicate the memory of President McKinley, to whom the "forcible annexation" of peoples meant " criminal aggression " and who, upon taking over the Philippines "for high duty in the interest of their inhabitants and for humanity and civilization" solemnly said: "Our sacrifices were with this high motive. We want to improve the condition of the inhabitants, securing them peace, liberty, and the pursuit of their highest good.'

Thus, finally, America will carry out the efforts 
and assurances of President Wilson when, upon the signing of the armistice, he said to the Filipinos : "I hope and believe that the future holds brighter hope for the states which have heretofore been the prey of great powers and will realize for all the world the offers of justice and peace which have prompted the magnificent cooperation of the present war." (November 29,1918 .)

The Filipinos will thus have a better opportunity to demonstrate how deeply rooted is their gratitude for America when, after her voluntary withdrawal from these Islands, we preserve here the immortal spirit of her democratic institutions and associate with her in her future enterprises of justice and peace in carrying to the darkest corners of the earth, which lack happiness because their people do not control their own destinies, the quickening flame of justice, democracy, and liberty. 


\section{APPENDIX C}

\section{INSTRUCTIONS FROM THE COMMISSION OF INDEPENDENCE TO THE PHILIPPINE MISSION}

Manila, March 17, 1919.

By authority of the Philippine Legislature and acting under its instructions, the Commission of Inde. pendence has resolved that the following statement be sent to the Philippine Mission:

The Philippine Mission will please convey to the Government of the United States the frankest assurances of the good-will, friendship, and gratitude of the Filipino people and submit with as much respect as confidence the question of Philippine Independence with a view to its final settlement. The attention of the Government of the United States is respectfully invited to the summary of facts and propositions considered in the declaration of purposes approved by the Philippine Legislature on March 8th, 1919.

It is singularly fortunate for the Philippine Nation that there seems to be no controversy concerning either the pertinent principles or the capital facts of the matter. The Filipinos venture to believe that all that is necessary is a frank exchange of views in order to arrive in a prompt and satisfactory manner at a definite adjustment of details which will result in the complete and final execution of the plans outlined, in 
accordance with the principles already established and agreed upon.

It is well known that these principles are so old that many of them, and one may even say all of them, substantially already found faithful expression in the immortal days of 1776 when in the New World a people smaller and with less resources than the Filipino people entered upon the fearless undertaking of establishing a new government founded upon the proposition that its just powers were derived not from the will of Monarchs, but from the consent of the governed. It was not the first time that a people threw off the yoke of a foreign government; but it was the first case in which a people dissatisfied with the political bonds which had connected them with their former sovereign, invoking the laws of God and of Nature established the principles of liberty and justice, not only for themselves, but also for the other subject peoples of the world.

Having lived for over two decades side by side with the people of the United States, the Filipino people have become convinced that those principles are now as real and powerful as in the days when they were proclaimed. Although it has not been possible to avoid certain isolated expressions made in apparent violation of those principles, yet it cannot be denied that the only authorized declarations regarding the American policy in these Islands have been specific and decisive and having been reiterated from time to time have led the Filipino people to believe, as they have with good reason believed, that the purposes of 
America were not of domination or self-aggrandizement, but of altruism, humanity, and liberty.

On the basis of this understanding, the attitude of the Filipinos has been one of confident waiting. Busily engaged in the reconstruction that necessarily followed the war as well as in the reaffirmation of their personality, the Filipino people have exercised the political powers conferred upon them as best they knew, first giving their loyal and peaceful cooperation and subsequently assuming an almost complete control of their internal affairs. Their national record of over twenty years from the first day of American occupation until the present is a living example of what they have done and is now unhesitatingly submitted to the examination and criticism of the world.

Moreover, the triumph of democracy in the moral and political revaluation of human institutions through the recent war has infused new life into the principles enunciated in 1776 and in fact has confirmed and ratified the promises of 1916. The Filipino people, seeing their own cause involved in the cause of the United States in that war, gave their support to the same. They not only placed all their modest energies and resources at the service of America, but in the spirit of a real and active community of ideals and interests they resolutely assumed the international responsibilities of that country in the Philippines. It will not be amiss to say now that during all that time of commotion and restlessness the public order was maintained here as perfectly as in the preceding years and the American flag continued to float 
undisturbed not because it was supported by a military force of which there was hardly any, but because of the loyal and vigilant allegiance of the Filipinos.

Now that the war is over and the world is engaged in applying in the concrete the principles that have come out triumphant from it; now that the Filipino people have passed the tests to which their capacity has been submitted: Can it be deemed inopportune or ill-advised for them to submit the pending question to the United States, or even to any other competent tribunal of the world for its final adjustment? The problem being so varied in its aspects, the Filipino people will welcome an opportunity to discuss the terms of the concession of Independence and the scope of the covenants necessary for the guaranty, safety and stability of the new State and for the establishment and maintenance of such external relations, especially with America, as may be equitable and beneficial and as the circumstances may demand. In this respect they cannot but be guided by the spirit of the steps previously taken with the Government of the United States, especially by the reason of mutual understanding and benefit that were taken into account when the Independence Bill of 1914 was drafted. Inasmuch as the situation of the international affairs has been altered by the irresistible force of the principles consecrated by the recent war, it is evident that the plan contained in that bill can not be carried into effect without certain suitable revisions. One of them is that inasmuch as the Filipino people believe in the 
efficacy of a general concert of responsible powers established for the common cause of justice and the preservation of the peace of the world, they would be ready to agree to any arrangement by which the Philippines would be enabled to participate in the concert as soon as possible.

The Filipino people would not be just to themselves if, at this moment when their political separation from the sovereign country is being proposed, they should fail to express in the clearest and most definite manner the sentiments and purposes that inspire their action. They therefore deem it their duty to affirm: That Independence, instead of destroying or weakening, will tend to strengthen the bonds of friendship and appreciation created by the gratitude of the Filipino people, not only for the final measure of complete justice and humanity that they confidently expect, but for all the previous disinterested work so splendidly performed for the benefit of the Philippines by so many faithful sons and daughters of America; that this gratitude will be the first fundamental fact in the future relations between the United States and the Philippine Islands ; that in the present state of the international affairs the Filipino people merely aspire to become another conscious and direct instrument for the progress of liberty and civilization; that in the tranquil course of their years of constitutional development they will maintain for all people inhabiting their hospitable land the essence and benefit of democratic institutions; that they will continue to associate, in so far as this will be acceptable and their 
strength will permit, in the work of reconstruction, justice, and peace carried on by the United States in continuation of those other undertakings, the high purpose of which was the cause, according to President Wilson, " of the magnificent cooperation between the American and Filipino peoples during the war"; and, finally, that in thus preserving their best traditions and institutions in the new situation which will strengthen and perfect them, the Filipino people will continue to make this country as heretofore a safe place of law and order, Justice and Liberty where Americans and foreigners as well as Nationals may live peacefully in the pursuit of happiness and prosperity and safe in the enjoyment of their property as well as of their rights and their liberty.

Sergio Osmeña,

Speaker, House of Representatives.

Espiridion Guanco, Acting President, Philippine Senate. 



\section{INDEX}

$\mathbf{A}$

Abbott, James A., on Filipino subjugation, 163, 164; on Japanese colonization of Formosa, 164; on Japanese expansion in Korea and Manchuria, 165.

Act, land settlement, of California, 89.

Acts, of Congress of U. S.: Organic (1902), $9,29,44$, 151 ; Jones law, references to, 14, 25, 27, 28, 29, 32, 34, $36,39,40,51,52,72,77$, $110,125,127,143,151,177$, 178,181 ; Approved by Republicans and Democrats, 15; Clarke amendment to, 14 ; attitude of Republicans on, 14; Passed by House and Senate, 15; Authorization to President to call Philippine National Guard into federal service, 63; Law making scouts officers and enlisted men available for National Guard, 64. Acts, of Philippine legislature: Miscellaneous, passed between Apr. 3, 1915, and Feb. 24, 1916: 48, 49, 50; Nos. 2501, 95, 96; No.
2586, 96 ; Nos. 2396, 2406, $2413,2417,2522, \quad 2539$, $2545,2658,2662,2664$ : 97 ; No. 2156, 105; Nos. 2208, 2404, 2444: 110; No. 2674, 111; Administrative code, 94, 99, 100; Concurrent resolution No 7: 144; Concurrent resolution No. 11: 147; Of Philippine Commission, Acts Nos. 82, 83: 94.

Adams, Secretary, on independence of Venezuela, 132. Agricultural possibilities in Philippines, 175.

Appropriations, for schools, 104 ; for roads, bridges and ferries, 106; for non-Christians, 120; for artesian wells, 107; miscellaneous, $48,49,50$; also see Acts. Artesian wells, number of, 87 ; expenditures for, 107. Assembly, national, in 1907, 21 ; speaker of, $21,22,25$; limited power of, 23 ; unity of leadership in, 24.

\section{B}

Bagehot, statement of, on English government, 39, 40. 
Bailey, General, approval of Philippine National Guard, 64.

Baker, Newton D., Secretary of War, on Filipino autonomy, 42 ; on Philippine government, 42; on Filipino self-restraint, 70,71 .

Benito, Datu, appointment of, $125,126$.

Bills, appropriation, initiation of, 46 ; list of, 48,49 , 50.

Board, provincial, constitution of, 95, 97.

Bryan, Wm. J., on stable government, 141, 142

Budget, showing state of finances, 58.

Budget system, origin of, 44 ; consideration of, 51; approval of, 55; importance of, 56

Buildings, public, expenditures for, 106, 107.

Butu, Senator Hadji, 118 ; appointment of, 125, 126; statement of, 128

\section{C}

Cabinet, Philippine, on preparation of budget, 54 .

Capital, American and other, in Philippines, 82, 90, 91.

Carpenter, Frank W., statement of, 127 .

Cases, administrative, against municipal officials, 100 , 101.
Central Luzon agricultural school, 116.

Church and state, separation of, in Moro country, 121 to 128, inclusive.

Cigar factories, in Philippines, 86.

Clarke amendment, relation of, to Jones bill, 14; attitude of Republicans on, 14 ; passed by Senate, 15; also see Acts.

Claudio, Tomas, service of, 61.

Coal, in Philippines, 88; National Coal Company, 88.

Cocoanut oil, 85.

Colonial government, American, in Philippines, 18 et seq.

Commerce, foreign, 1913 and $1918,78,79,80,81,82$.

Commercial possibilities, in Philippines, 90, 91, 175, 176.

Commission of Independence, special instructions of, for guidance of Philippine Mission, See Appendix C, 196, 197, 198, 199, 200, 201.

Commissioners, Resident, to the United States, 9; work of, on Jones law, 16.

Constitution, Malolos, on sovereignty, 171.

Corporations, domestic, in Philippines, 82.

Cotabato, valley of, agricultural possibilities of, 175 . Council of State, purpose, 37, 
38; composition of, 37,38 , 41 ; first action of, 38,39 ; preparation of budget by, 54, 56.

Crow, Carl, statement of, 163.

\section{D}

Davao, Japanese immigration to, 164 .

Debt, national, amount of, 57.

Declaration of Purposes, of Philippine Legislature, for Independence Commission, See Appendix B, 183 to 195 , inclusive.

\section{E}

Economic development, in Philippines, 76 to 91, inclusive.

Education, Bureau of, for food production, 67, 68; ap. propriations for, 104.

Engineering companies, in Philippines, 84.

Evans, General R. K., relation of, to National Guard, 63 ; criticisms of, $63,64,65$, 66.

\section{F}

Filipino people, loyalty of, during war, 59, 60, 61, 69, 70,71 ; destroyer and submarine offered by, to U. S., 60 ; liberty bonds taken by, 60; Red Cross work by, 60 ,
61 ; services offered by, 61; seli-restraint of, $69,70,71$; progress of, 107, 108.

Filipino women, position of, in Orient, 173; education of, 174 ; number of girls enrolled in primary and intermediate grades, 174; positions occupied by, 174; women's clubs, 68,174 ; influence of, 173, 174, 175; Emma Sarepta Yule on, $173,174,175$.

Finance, Department of, in preparation of budget, 53, $54,55$.

Formosa, Japanese colonization in, 164.

Freedom, Filipino desire for, 178.

Frontier problems of Philippines, Asia, Siam, India and China, 159, 160, 161.

G

Governor-General, position of, under Jones law, 27; statement of, on Filipino autonomy, 41 ; budget powers of, $45,46,52$; complaint of, to Secretary of War, against Gen. Evans, 65; declaration of, on capacity Filipino people, 149, 153, 154.

Grant, President, statement of, on stable government, $130,131$.

Greene, General, relief of General Evans by, 65. 


\section{H}

Harrison, Governor-General Francis Burton, statement of, 28,42 ; message of, on fiscal matters, 47 ; on formation of budget, 52,53 ; on finances, 56,57 ; letter of, to Gen. Evans, 64; on Filipino capacity, 149, 153, 154.

Health Service, Philippine, 90.

Home owners, per cent of, in Philippines, 172.

Imports and exports, of Philippines, $77,78,79,80,81$. Independence, Philippine: The Democratic Party on, 5, 142-143; Root on, 12; Roosevelt on, 12; Taft on, 12; Wilson on, 13; Jones Law, a covenant, 16, 17; Clarke Amendment, attitude of Republicans on, 14; Filipinos restrained movement for, during war, 70; self-determination, 71,72 ; Philippine Mission for, 89 ; Non-Christian tribes and attitude of labor toward, $89,126,128$; stable gov. ernment, prerequisite to, 119 et seq.; Commission of Independence, 144, 158, 177; Instructions to, 146; Philippine Mission to
United States for Independence, 147, 148; Governor General Harrison on, 153; Japan and, 161 et seq.

Insurance companies, in $\mathrm{Phil}$ ippines, 84.

Iyenaga, Dr., on Japan's attitude toward Philippines, $165,166$.

\section{J}

Jackson, President, message of, on independence of Texas, 133, 134.

Japanese, subjugation of Filipinos by, 163, 164; in Korea, 165; in Manchuria, 165 ; attitude toward Philippines, 165, 166; Philippine attitude toward, 167 ; reverence to Mikado, 169, 170.

Jones, Representative William Atkinson, statement of on Jones law, 16, 17.

Jones, General R. W., on national guard, 63; statement of, on relief of General Evans, 65, 66.

Jones bill, date of passage, 3 ; relation of, to Jones law, 15.

Jones law, effect of, on Filipino-American relationship, 14; preamble of, 14; preamble complete, See Appen$\operatorname{dix} A, 181$; sanction of, by American people, 15; as compact between Filipino 
and American peoples, 16, 40 ; purpose of, 40 ; departments created by, 35 ; Section 21 of, 52; on Moro problem, 110.

Judiciary, composition of, 39 ; non-political character of.

\section{K}

Kawakami, K., on Japan's desire to acquire Philippines, 166.

Koran, use of, 116.

Korea, annexation of, by Japan, 160 ; number of Japanese in, 165 .

\section{L}

Labor, Bureau of, creation of, 88,89 ; directors of, 89.

Laborers, Philippine, parade of, 69 .

Legislature, Philippine, (See Acts) rivalry between two houses of, 33; harmony between two houses of, 33; system - of calling department heads before, 33, 34, 35 ; resolution of, on gratitude to U. S., 73, 74.

Leper colony, Culion, 90.

Literacy, in Philippines, 169.

Local government, Filipinization of, 92 to 108 , inclusive; success of, 107, 108.

Loyalty, Filipino, during war, 569 to 75 , inclusive.
Mabini, Apolinario, democratic idea of, $170,171$.

Magoon, Judge, on Cuban institution, 139, 140.

Malolos, constitution adopted at, 171.

Manchuria, Japanese in, 165.

Manila Railroad Company, transfer of, to Philippine government, 87.

McKinley, President William, on Philippine conditions, 4; assertion of, on Filipino desire of American sovereignty, 5; answer of, to democrats on Philippine independence, $5,6,142$; on fundamental aim of American government, 11; message of, on Cuban situation, 131, 134.

Mediation, between Philippine capital and labor, 88, 89.

Memorials, of Moros to Philippine legislature, 126.

Mercantile import and export companies, in Philippines, 84, 85.

Mikado, reverence of Japanese toward, 169, 170.

Militia, Philippine, organization of, 61,62

Mindanao and Sulu, Department of, organization and government of, schools in, $113,114,115,116,117,118$, 
Monetary circulation, $19 \Gamma 3$ and 1918,81 .

Moros, civilization of, 120 ; separation of church and state, 121 to 128 inclusive; memorial of, to Philippine legislature, 126.

Municipalities, number of, 93.

\section{$\mathrm{N}$}

Nacionalista party, as party in power, 33 ; president of, 33.

National debt, amount of, 57. National Development Company, creation of, 88 .

National guard, men enrolled in, 62; law of acceptance of, 63 ; delay in the organization of, 62, 63, 64, 65.

New York Herald, statement of an American correspondent to, as to Philippine independence policy, 76, 77 .

Nitobe, Dr., on Japan's policy toward Philippines, 162, 163.

Non-Christian tribes, 109 ; policy of Philippine Commission and Philippine legislature toward, 111, 112, 119 ; education and sanitary systems for, 112, 113; schools for, 113, 114, 115, 116; public works for, 118 , 119; agriculture in, 119 , 120.

Officers' school, organization of, $63,64,66$.

Orosa, Dr. Sixto, work among non-Christians, 118.

Osmena, Speaker Sergio, statement of, accepting Jones law, 17; leadership and ability of, 33,36 ; as Vice-President of Council of State, 38.

Okuma, Count, on Japan's purposes, 166.

\section{$\mathbf{P}$}

Palma, Senator Rafael, on department heads, 34,35 ; as Vice-President Philippine Mission, 147.

Paris Peace conference, problems before, 160,161 .

Partnerships, domestic, in Philippines, number of, 82. Perry, Commodore, relation to Japan's development and success, 180.

Philippine National Bank, organization and resources of, $81,83$.

Philippine News Revievo, purpose of, 67 .

Philippines, population of, 109; non-Christians in, 109; geographical position of, 160,161 ; area of, 175 ; undeveloped resources of, 175; possibilities of, 175, 176. 
Piang, Datu, appointment of, 125, 126.

Platform, Democratic, on stable government, 143 .

Politival leaders, in Philippines, 171.

Provinces, number of, 92 ; division of, 92,73 ; acts governing, 94, 95, 96; supervision of, $98,99,100$; revenues of, 101.

\section{Q}

Quezon, Manuel L., in inaugural address, as President Philippine Senate, 32; on Secretaries' responsibility, 34 ; views of, as to amount of Filipino autonomy, 41; offer of, to U. S., of Filipinos' services in war, 62; speech of, before American Secretary of War, 147, 148; leadership and ability of, 171.

Railroads, nationalization of, 87.

Red Cross, Philippine chapter, war activities, 60, 61, $68,69$.

Reorganization act, its scope, 35.

Revenues, provincial, 101.

Rizal, Jose, 20, 60.

Roads, public, 1914 and 1918, 86, 87, 106; expenditures for, 87, 106.

Roosevelt, Vice-President, on
Filipino civilization, 7; hope of, 12.

Root, Elihu, suggestion of, 137, 148, 149.

S

Sanitary districts, number of, $105,106$.

Schools, in Philippines, num. ber of, 103; appropriations for, 104; expenditures for, in non-Christian tribes, $112,113,114$.

Self-determination, President Wilson on, 71, 72.

Senate, Philippine, creation of, 26 ; powers of, 26,27 , 28 ; statement of GovernorGeneral on, 28; popular eharacter of, 32,33 .

Shipping companies, in Philippines, 84, 85.

Spain, political service of, to Philippines, 19; campaign in for Philippine reforms, 20.

Stable government, defined, 129 to 136 , inclusive; meaning of, in Texas, 133, 134; meaning of, in Cuba, 130, 131,134 to 143 , inclusive; meaning of, in Jones law, 141, 142, 143; President McKinley, on meaning of, 134, 135; existence of, in Philippines, 141, 149, 150, 151,152 ; already established in Philippines, 151, 152. 
Sugar, in Philippines, 87, 88; Sugar Central board, 87, 88; investments in, by the Philippine government, 88.

Sulu, Sultan of, 122.

\section{$\mathbf{T}$}

Taft, Wm. H., on President McKinley's policies, 11 ; assertion of, as Secretary of War, 12; message of, to Congress, 12 ; statement of, on Cuban election, 139, 140; on contrast of Filipinos with other Malay and Oriental peoples, 168.

Taxation, in Philippines, 1913 and 1918, 81, 82 .

Trade, Philippine, 1913 and $1918,77,78,79,80$; table showing foreign trade with Philippines, 79.

Treaty of Paris, on Philippine Republic, 3; on decision of America have all islands or none, 161 .

\section{$\mathbf{U}$}

Uyehara, G. E., on Emperor of Japan, 169, 170.
V

Voters, in Philippines, 169.

W

Waloe, Colonel Ole, memoran. dum of, to Department secretary, 122, 123, 124, 125.

Wells, artesian, 1913 and $1918,87$.

Woman's Club of Manila, campaign of, for food production, 68.

Wilson, President Woodrow, assurances of, on Philippine independence, 13; statements of, on American purposes in war, 71, 72; answer of, to resolution of gratitude of Philippine legislature, 74, 75; speech of, at Staunton, Va., 76; reply of, to Philippine Mission, $156,157$.

Wood, General Leonard, on Cuban constitution, 136, 137.

\section{Y}

Yeater, Vice-Governor C. E., statement of, on Filipino capacity, 154, 155, 156.

Yule, Emma Sarepta, on Filipino women, 173, 174, 175. 


University of California

SOUTHERN REGIONAL LIBAARY FACILITY

405 Hilgard Avenue, Los Angeles, CA $90024-1388$

Return this material to the library from which it was borrowed.
RARY

d below.

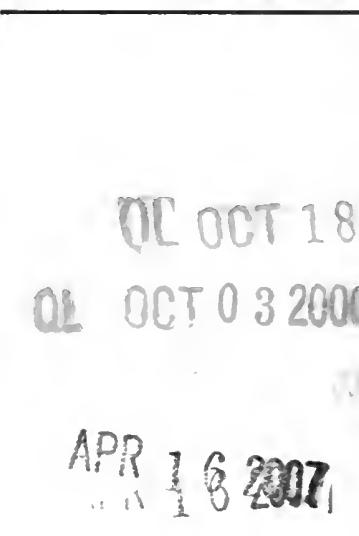




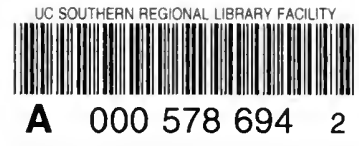


Hor

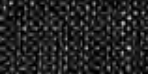 \\ $8 \%$}

